Universidad

Politécnica

de Cartagena
Universidad | Campus Politécnica de Excelencia de Cartagena Internacional

\title{
DEVELOPMENT OF INNOVATIVE AND HIGH NUTRITIONAL VALUE FOODS FROM NATIVE LEGUME SPECIES
}

DOCTORADO EN TÉCNICAS AVANZADAS EN INVESTIGACIÓN Y DESARROLLO AGRARIO Y ALIMENTARIO

\section{Elena Collado Marín}

Directora: Dra. Perla Gómez Di Marco

Co-Director: Dr. Francisco Artés Hernández 


\section{CONFORMIDAD DE SOLICITUD DEAUTORIZACIÓN DE DEPÓSITO DE} TESIS DOCTORAL POR EL/LA DIRECTOR/A DE LA TESIS

D a PERLA AZUCENA GÓMEZ DI MARCO, Directora, y D. FRANCISCO DE ASÍS ARTÉS HERNÁNEZ, Codirector, de la Tesis doctoral "DEVELOPMENT OF INNOVATIVE AND HIGH NUTRITIONAL VALUE FOODS FROM NATIVE LEGUME SPECIES".

\section{INFORMAN:}

Que la referida Tesis Doctoral, ha sido realizada por Da. ELENA COLLADO MARÍN, dentro del Programa de Doctorado TÉCNICAS AVANZADAS EN INVESTIGACIÓN Y DESARROLLO AGRARIO Y ALIMENTARIO, dando nuestra conformidad para que sea presentada ante el Comité de Dirección de la Escuela Internacional de Doctorado para ser autorizado su depósito.

$\mathrm{X}$ Informe positivo sobre el plan de investigación y documento de actividades del doctorando/a emitido por el Director/ Tutor (RAPI).

La rama de conocimiento en la que esta tesis ha sido desarrollada es:

Ciencias

Ciencias Sociales y Jurídicas

$\mathrm{X}$ Ingeniería y Arquitectura

En Cartagena, a 17 de enero de 2020

LA DIRECTORA DE LA TESIS

Fdo.:
EL CODIRECTOR DE LA TESIS

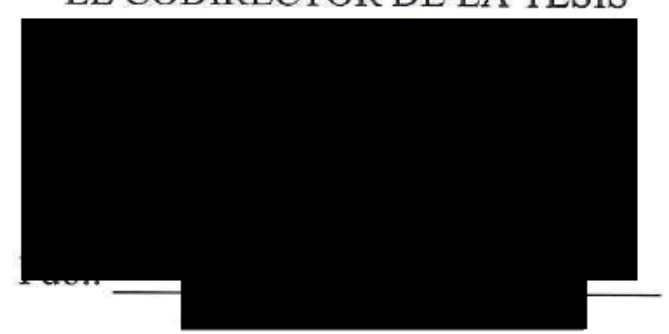




\title{
CONFORMIDAD DE DEPÓSITO DE TESIS DOCTORAL
}

\section{POR LA COMISIÓN ACADÉMICA DEL PROGRAMA}

D. Raúl Zornoza Belmonte, Secretario de la Comisión Académica del Programa TÉCNICAS AVANZADAS EN INVESTIGACIÓN Y DESARROLLO AGRARIO Y ALIMENTARIO

\section{INFORMA:}

Que la Tesis Doctoral titulada, "DEVELOPMENT OF INNOVATIVE AND HIGH NUTRITIONAL VALUE FOODS FROM NATIVE LEGUME SPECIES", ha sido realizada dentro del mencionado Programa de Doctorado, por $\mathrm{D}^{\mathrm{a}}$. ELENA COLLADO MARÍN, bajo la dirección y supervisión de la Dra. PERLA AZUCENA GÓMEZ DI MARCO y el Dr. FRANCISCO DE ASÍS ARTÉS HERNÁNDEZ.

En reunión de la Comisión Académica, visto que en la misma se acreditan los indicios de calidad correspondientes y la autorización del Director/a de la misma, se acordó dar la conformidad, con la finalidad de que sea autorizado su depósito por el Comité de Dirección de la Escuela Internacional de Doctorado.

$\mathrm{X}$ Evaluación positiva del plan de investigación y documento de actividades por el Presidente de la Comisión Académica del programa (RAPI).

La Rama de conocimiento por la que esta tesis ha sido desarrollada es:

\author{
Ciencias \\ Ciencias Sociales y Jurídicas \\ $\mathrm{X}$ Ingeniería y Arquitectura
}

En Cartagena, a 18 de enero de 2020

\section{EL SECRETARIO DE LA COMISIÓN ACADÉMICA}

\author{
RAUL \\ Firmado digitalmente por RAUL \\ ZORNOZA|BELMONTE \\ Nombre de reconocimiento (DN): \\ $\mathrm{cn}=$ RAUL|ZORNOZA|BELMONTE \\ Fdo: \\ serialNumber \\ givenName=RAUL, sn=ZORNOZA \\ BELMONTE, ou=Ciudadanos, \\ BELMONTEE \\ Fecha: 2020.01 .18 08:35:13 +01'00'
}


This thesis is a compendium of papers previously published or accepted for publication. It consists of the following articles:

- Collado, E., Klug, T.V., Martínez-Sánchez, A., Artés-Hernández, F., Aguayo, E., Artés, F., Fernández, J.A. , Gómez, P.A. (2017). Immature pea seeds. Effect of storage under modified atmosphere packaging and sanitation with acidified sodium chlorite. Journal of the Science of Food and Agriculture. 97: 4370-4378. http://dx.doi.org/10.1002/jsfa.8513.

- Collado, E., Venzke Klug, T., Martínez-Hernández, G.B., Artés-Hernández, F., Martínez-Sánchez, A., Aguayo, E., Artés, F., Fernández, J.A., Gómez, P.A. (2019). UV$\mathrm{C}$ pretreatment of fresh-cut faba beans (Vicia faba) for shelf life extension: Effects of domestic microwaving for consumption. Food Science and Technology International. In press. https://doi.org/10.1177/1082013219873227.

- Collado, E., Venzke Klug, T., Artés-Hernández, F., Aguayo, E., Artés, F., Fernández, J.A., Gómez, P.A. (2019). Quality changes in nutritional traits of fresh-cut and then microwaved cowpea seeds and pods. Food and Bioprocess Technology. 12: 338-346. http://dx.doi.org/10.1007/s11947-018-2214-2.

- Collado, E., Venzke Klug, T., Martínez-Hernández, G.B Artés-Hernández, F., Martínez-Sánchez, A., Aguayo, E., Artés, F., Fernández, J.A., Gómez, P.A. (2019). Nutritional and quality changes of minimally processed faba (Vicia faba L.) beans during storage: Effects of domestic microwaving. Postharvest Biology and Technology. https://doi.org/10.1016/j.postharvbio.2019.01.008. 


\section{ACKNOWLEDGEMENTS}

First of all I would like to thank my Thesis Directors, Dr. Perla Gómez and Dr. Francisco Artés Hernández, for the opportunity they gave me to carry out my Doctoral Thesis under their tutelage and the trust they have shown on me, for all their support, guidance and patience. In addition, my most sincere gratitude to Dr. Francisco Artés Calero and Dr. Encarna Aguayo, for their insightful comments and encouragement.

I am also grateful to the Eurolegume Project for financial support of the experiments through the Seventh Research Framework Programme of the European Union - FP7 Research Project no. 613781.

I would also like to thank Dr. Ascensión Martínez, for her friendship, patience and teachings that have made this thesis possible; Dr. Ginés Benito Martínez, for his knowledge; and Dr. Mariano Otón, without whom no thesis would have come to fruition.

Also, my great gratitude to all my laboratory colleagues during these years, who have helped me in every way possible and offered their friendship, both outside and inside the laboratory: Noelia, Maria José, my engineer José Ginés, Gerardo, Laura, Javi; and the students Alexandra, Mayca, Mar, Paula, Simona, Daniella. Special mention to Lizette, who has continued to accompany and help me even with an ocean in between. And of course, a thousand thanks to Tàmmila, there are no words to express all that she has helped me in my thesis and in my life.

Finally, I would like to thank my family, who have always supported me and have been proud of everything I have done. 


\section{INDEX}

ABSTRACT

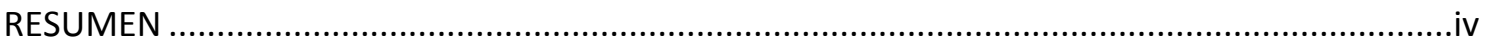

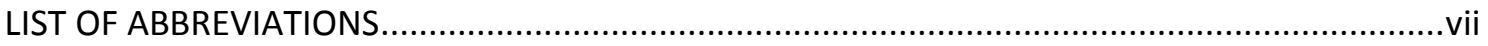

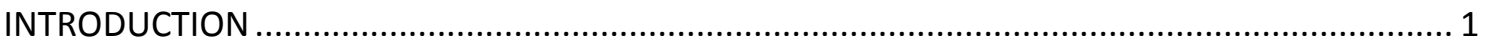

1. BOTANICAL AND AGRONOMICAL CHARACTERISTICS OF FABA BEANS, PEAS AND COWPEA1

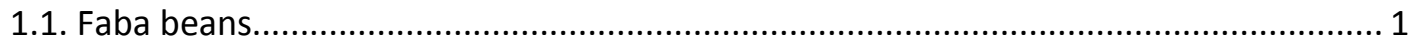

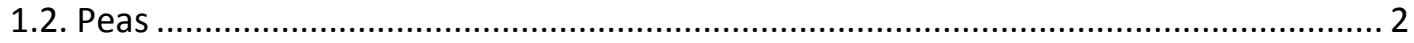

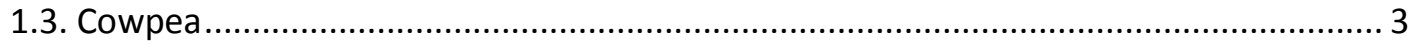

2. NUTRITIONAL, BIOACTIVE AND NON-NUTRITIONAL COMPOSITION OF FABA BEANS, PEAS

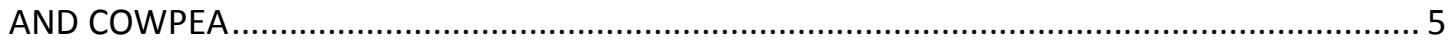

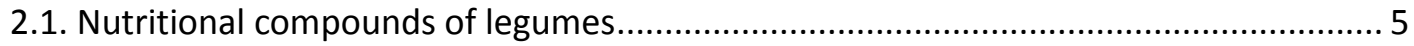

2.2. Main nutritive and bioactive compounds of faba beans, peas and cowpea ................. 7

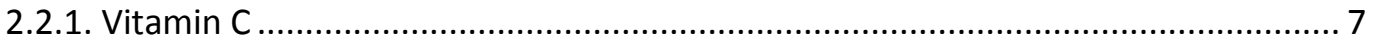

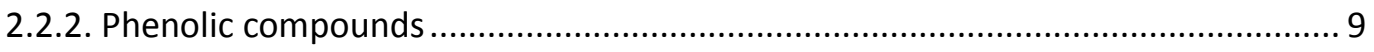

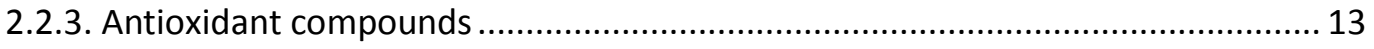

2.3. Main non-nutritional factors in legumes ................................................................... 17

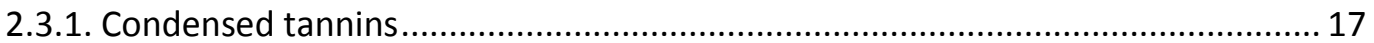

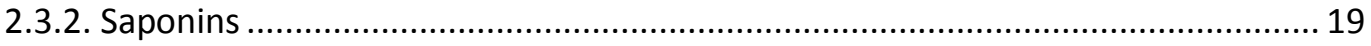

2.3.3. Raffinose

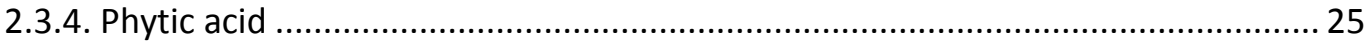

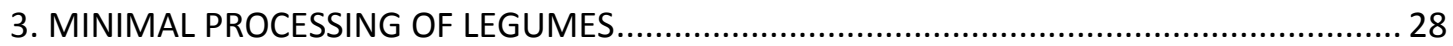

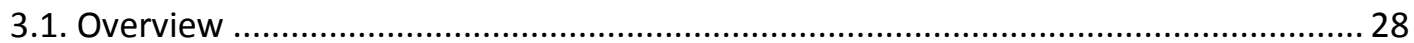

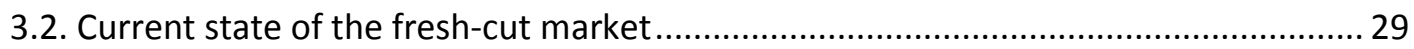

3.3. Units operations during minimally fresh product processing ...................................... 30

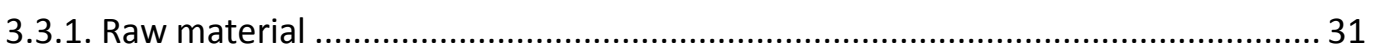

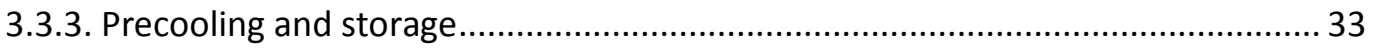

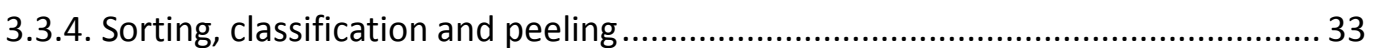

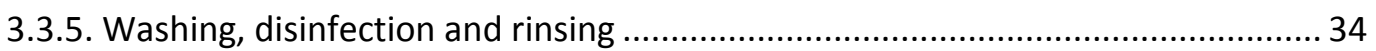

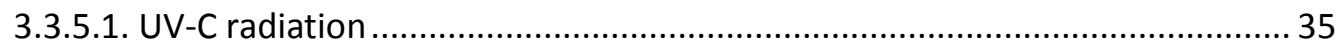

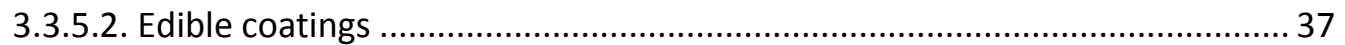

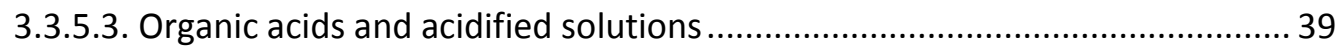

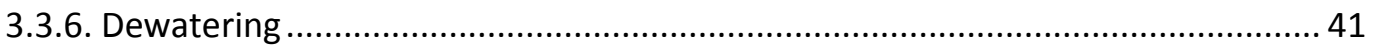

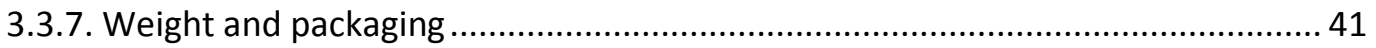

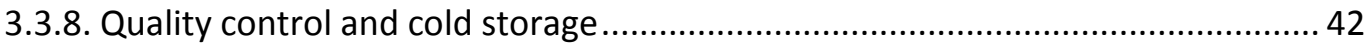

3.3.9. Cold transportation and distribution ............................................................... 42 
3.4. Overall quality and safety of fresh cut vegetables .................................................... 43

3.4.1. Physiological, physical and pathological disorders .............................................. 43

3.4.2. Nutritional and bioactive compounds changes.................................................. 44

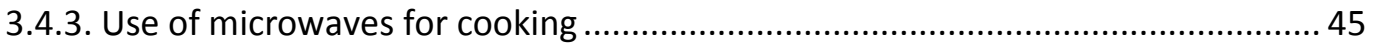

3.4.4. Safety aspects of fresh cut vegetables ............................................................... 45

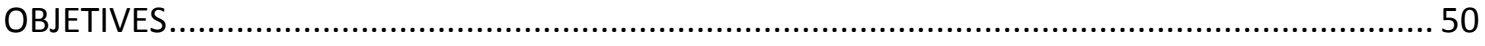

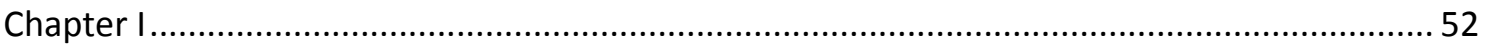

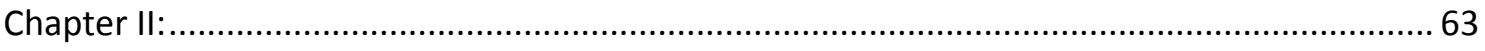

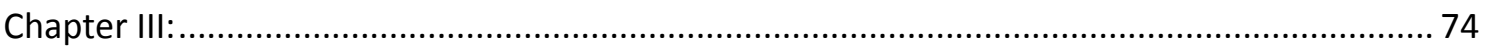

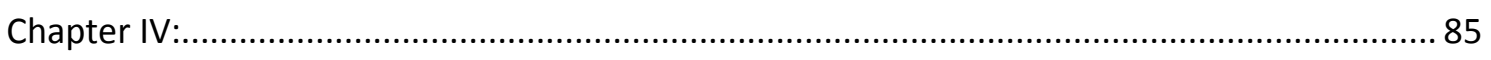

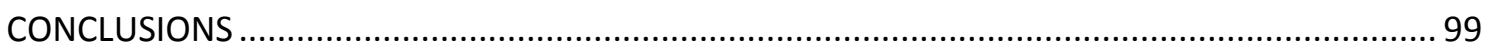

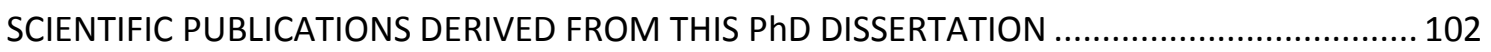

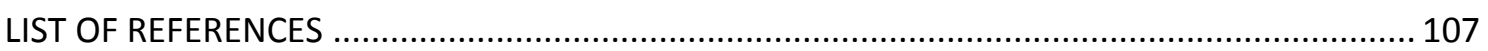

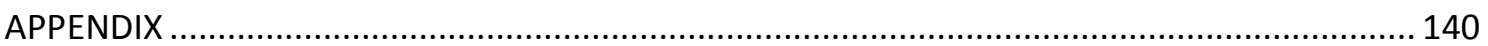




\section{ABSTRACT}

There is nowadays an important trend in the habits of human food consumption in which natural, healthy, ready-to-eat and safe elaborates are required. An example of this trend is the development of fresh-cut or minimally processed fruit and vegetables. Legumes are an excellent source of many essential nutrients, including proteins and aminoacids, minerals, fiber, vitamins, slow-assimilation carbohydrates and other bioactive compounds, and are low in calories and fat. However, the bioavailability of some nutrients can be reduced by several legume compounds, which are considered to be antinutritional compounds. Nevertheless, such compounds have also been reported to have beneficial health properties. Therefore, the consumption of legumes should be promoted by looking for new ways of presentation in where the product can be consumed fresh and cooked in a suitable container.

Legumes are usually consumed as fresh seeds. However, different cooking methods can also be used. This food preparation may cause changes in texture, colour, flavour, or bioactive content. One of these methods is microwave cooking, in which a healthy product could be obtained in a short time without loosing quality.

One of the most critical steps in the development of fresh-cut products is disinfection. Although the use of $\mathrm{NaOCl}$ is widespread in the industry due to its antimicrobial activity and low cost, it is examined due to the appearance of toxic by-products. Therefore, the study of alternative sanitizing methods is necessary. Others disinfectants, like acidified sodium chlorite (ASC) have been largely applied for the prevention of enzymatic and non-enzymatic browning and, in less extent, to reduce microbial growth at levels that did not adversely affect the sensory quality. Furthermore, UV light can also be an alternative, useful for superficial decontamination, because UV light acts as an antimicrobial agent directly by damaging the microbial DNA and indirectly due to the stimulation of defence mechanisms in vegetables against pathogens, retarding decay and delaying senescence. In addition, edible antimicrobial films or coatings can avoid enzymatic browning and improve quality, safety, shelf life and functionality of food products by reducing moisture transfer, respiration rate and oxidative processes, while minimizing both spoilage and pathogenic microorganisms. 
The general objective of this Thesis was to optimize processing steps to develop new fresh and processed foods from native varieties of three legumes species (faba beans, peas and cowpeas). Such legumes are well adapted to several European climates and with high nutritional quality and high content in bioactive compounds. In that way, food of local origin with high protein content could be easily included in the human diet.

For fresh produce disinfection, the effects of $\mathrm{NaOCl}(100 \mathrm{ppm})$ or alternatively ASC (300 ppm) stored under modified atmosphere packaging at 1 or $4^{\circ} \mathrm{C}$, on quality of freshcut immature pea seeds were evaluated. Disinfection with ASC resulted in better sensory quality, higher content of vitamin $\mathrm{C}$ and lower psychrofiles counts. Immature pea seeds could be stored up to 14 days at $1-4^{\circ} \mathrm{C}$ under MAP with only minor quality changes.

Subsequently, the effect of different sanitizers $(\mathrm{NaOCl}(150 \mathrm{ppm}), \mathrm{NaOCl}+$ an edible coating based of sucrose fatty acid esters (EC) and UV-C (3 kJ m $\left.\left.{ }^{-2}, 90 \mathrm{~s}\right)\right)$ on quality changes of minimally processed faba seeds stored for 10 days at $4^{\circ} \mathrm{C}$ were studied. Periodically, samples were microwaved $(700 \mathrm{~W}, 1 \mathrm{~min})$ to obtain a ready to eat food. The EC treatment showed a positive effect on vitamin $\mathrm{C}$, total phenolics content and tannins content retention, whereas UV-C treated samples showed the highest sugars content values. Additionally, EC or UV-C treatments extended the shelf life of fresh-cut faba seeds from 7 to 10 days at $4^{\circ} \mathrm{C}$ regarding $\mathrm{NaOCl}$ treatment. As expected, microwaving decreased the concentration of bioactive compounds, but retained the quality of faba seeds allowing to obtain a ready to eat tasteful food.

Furthermore, the quality of fresh-cut cowpea, prepared to be eaten raw (immature seeds) or microwaved (seeds and pods), was also evaluated. Fresh cowpea pods were washed with $\mathrm{NaClO}\left(150 \mathrm{ppm}, \mathrm{pH} 6.5,2 \mathrm{~min}, 4^{\circ} \mathrm{C}\right.$ ) and stored for 21 days at $8^{\circ} \mathrm{C}$ under modified atmosphere packaging (23 $\mathrm{kPa} \mathrm{CO}_{2} / 1.5 \mathrm{kPa} \mathrm{O}$ and $19 \mathrm{kPa} \mathrm{CO} / 1.2 \mathrm{kPa} \mathrm{O}_{2}$ ). Additionally, seeds obtained from hulled pods were also disinfected, packaged and stored for 7 days at $4^{\circ} \mathrm{C}$. Total phenolic content (TPC), total equivalent antioxidant capacity (TEAC), sugars and sensory attributes, were evaluated. TPC and TEAC increased after microwaving (700 W, 1 min) for both seeds and pods. Concentration of sucrose and glucose increased after microwaving, while raffinose was not detected after cooking. According to sensory quality, fresh and microwaved seeds maintained all the 
evaluated attributes above the limit of usability after 7 days at $4^{\circ} \mathrm{C}$, while pods were edible up to 14 days at $8^{\circ} \mathrm{C}$.

Finally, the effects of a UV-C treatment $\left(3 \mathrm{~kJ} \mathrm{~m}^{-2}\right)$, compared with non-illuminated beans, were studied on the sensory and microbial quality and bioactive and antinutritional content of fresh-cut and then microwaved faba beans. UV-C treatment extended the fresh-cut faba bean shelf life from 7 to 10 days at $5^{\circ} \mathrm{C}$. Nevertheless, UV-C improved the condensed tannins reductions through storage compared with nonirradiated samples. Microwaving reduced the phytic acid and condensed tannins contents.

Since the general objective of this research is to optimize several processes to develop new fresh and processed foods from native varieties of three legume species (faba, pea and cowpea), to stimulate the consumption of these in the daily human diet, both for fresh and microwave consumption, It can be said that with the use of various minimal processing techniques using $\mathrm{NaOCl}$ alone or in combination with edible coatings, or alternatively with chemical (ASC) or physical (UV-C) disinfectants, vegetable products with high nutritional quality and high content of bioactive compounds, fresh and ready to eat, can be obtained. 


\section{RESUMEN}

Hoy en día existe una importante tendencia en los hábitos de consumo caracterizada por una demanda creciente de alimentos naturales, más sanos, listos para el consumo y seguros. Un ejemplo de esta tendencia es el desarrollo de frutas y hortalizas mínimamente procesadas. Dentro de estas últimas, las legumbres son una excelente fuente de muchos nutrientes esenciales, incluyendo proteínas y aminoácidos, minerales, fibra, vitaminas, carbohidratos de asimilación lenta y otros compuestos bioactivos, y son bajas en calorías y grasas. Sin embargo, la biodisponibilidad de algunos nutrientes puede verse reducida por diversos compuestos presentes en las legumbres, considerados como compuestos antinutricionales. No obstante, muchos de estos compuestos también han sido identificados como beneficiosos para la salud. Por lo tanto, se debe promover el consumo de legumbres buscando nuevas formas de presentación en las que el producto pueda consumirse fresco y además poder cocinarse en un envase adecuado.

Las legumbres se consumen generalmente en forma de semillas frescas, como productos mínimamente procesados. Sin embargo, también se pueden utilizar diferentes métodos de cocción. Esta preparación de alimentos puede causar cambios en la textura, color, sabor o en el contenido de compuestos bioactivos. Uno de estos métodos es la cocción en microondas, en la que se puede cocinar un producto sano en poco tiempo sin perder mucha calidad.

Uno de los pasos más críticos en el desarrollo de los productos mínimamente procesados es la desinfección. Aunque la utilización del hipoclorito sódico $(\mathrm{NaOCl})$ está muy extendida en la industria debido a su actividad antimicrobiana y su bajo costo, su uso se encuentra en entredicho debido a la formación de subproductos tóxicos. Por lo tanto, es necesario el desarrollo de métodos alternativos de desinfección. Otros desinfectantes, como el clorito sódico acidificado (ASC), se han aplicado ampliamente para la prevención del pardeamiento enzimático y no enzimático y, en menor medida, para reducir el crecimiento microbiano a niveles que no afecten negativamente al sabor y el aroma de los productos vegetales. Además, la utilización de luz UV también puede ser una alternativa al $\mathrm{NaOCl}$, ya que es efectiva para la descontaminación superficial, debido a que actúa como agente antimicrobiano tanto directamente, dañando el ADN microbiano, como indirectamente debido a la estimulación de los mecanismos de 
defensa de las hortalizas contra los patógenos, retardando la descomposición y retrasando la senescencia. Así mismo, las películas o recubrimientos antimicrobianos comestibles pueden evitar el pardeamiento y mejorar la calidad, la inocuidad, la vida útil y la funcionalidad de los productos alimenticios al reducir la transferencia de humedad, la frecuencia respiratoria y los procesos oxidativos, al tiempo que se reducen al mínimo tanto el deterioro como los microorganismos patógenos.

El objetivo general de esta investigación fue optimizar los principales procesos para desarrollar nuevos alimentos frescos y procesados a partir de variedades nativas de tres especies de leguminosas (habas, guisantes y caupí), bien adaptados a diferentes climas europeos y con alta calidad nutricional y alto contenido en compuestos bioactivos. De este modo, alimentos ricos en proteína de origen local podrían ser incorporados más fácilmente a la dieta, mejorando asó la diversidad de las zonas productoras.

En este trabajo se evaluaron los efectos de la desinfección con $\mathrm{NaOCl}$ (100 ppm) o alternativamente con clorito sódico acidificado (ASC) (300 ppm), y el envasado en atmósfera modificada pasiva (MAP) a 1 o $4^{\circ} \mathrm{C}$, sobre la calidad general de las semillas de guisantes inmaduras mínimamente procesadas. La desinfección con ASC resultó en una mejor calidad sensorial, un mayor contenido de vitamina $\mathrm{C}$ y un menor recuento en recuento de psicrófilos. Las semillas de guisantes inmaduras pueden almacenarse durante 14 días a $1-4^{\circ} \mathrm{C}$ bajo MAP, con leve impacto en su calidad.

Posteriormente, se estudió el efecto de diferentes desinfectantes ( $\mathrm{NaOCl}(150 \mathrm{ppm})$, $\mathrm{NaOCl}+$ recubrimiento comestible a base de ésteres de ácidos grasos de sacarosa (EC), y UV-C (3 $\left.\mathrm{kJ} \mathrm{m}^{-2}, 90 \mathrm{~s}\right)$ ) sobre los cambios de calidad de las semillas de haba mínimamente procesadas almacenadas durante 10 días a $4^{\circ} \mathrm{C}$. Periódicamente, las muestras se cocinaron en microondas $(700 \mathrm{~W}, 1 \mathrm{~min})$ para obtener un alimento listo para el consumo. El tratamiento con EC mostró un efecto positivo sobre la vitamina $\mathrm{C}$, el contenido total de fenoles (TPC) y la retención del contenido de taninos, mientras que las muestras tratadas con UV mostraron los valores más altos de contenido en azúcares. Además, los tratamientos de EC y UV extendieron la vida útil de las semillas de haba mínimamente procesadas de 7 a 10 días a $4^{\circ} \mathrm{C}$ con respecto al tratamiento con $\mathrm{NaOCl}$. Como era de esperar, el microondas redujo la concentración en compuestos bioactivos, 
pero mantuvo la calidad de las semillas de haba, lo que permitió obtener un alimento sabroso listo para consumir.

Otro de los objetivos de este trabajo fue evaluar la calidad de caupí mínimamente procesado listo para su consumo en crudo (semillas inmaduras) o cocinado en microondas (semillas y vainas). Las vainas de caupí frescas se lavaron con $\mathrm{NaOCl}$ (150 ppm) y se almacenaron durante 21 días a $8^{\circ} \mathrm{C}$ bajo atmósfera modificada $(23 \mathrm{kPa}$ $\mathrm{CO}_{2} / 1.5 \mathrm{kPa} \mathrm{O}$ and $19 \mathrm{kPa} \mathrm{CO} / 1.2 \mathrm{kPa} \mathrm{O}_{2}$ ), mientras que las semillas también fueron desinfectadas, envasadas y almacenadas durante 7 días a $4^{\circ} \mathrm{C}$. Se evaluó el TPC, la capacidad antioxidante equivalente total (TEAC), los azúcares y la calidad sensorial. El TPC y el TEAC aumentaron sus concentraciones después del cocinado con microondas tanto para las semillas como para las vainas. La concentración de sacarosa y glucosa aumentó después del microondado, mientras que la rafinosa no se detectó después de la cocción. Con respecto a la calidad sensorial, las semillas frescas y microondadas mantuvieron todos los atributos evaluados por encima del límite de aceptabilidad después de 7 días a $4^{\circ} \mathrm{C}$, mientras que las vainas fueron comestibles hasta 14 días a $8^{\circ} \mathrm{C}$.

Finalmente, se estudiaron los efectos del tratamiento UV-C $\left(3 \mathrm{~kJ} \mathrm{~m}^{-2}\right)$, en comparación con semillas no tratadas, sobre la calidad sensorial y microbiana, y el contenido bioactivo y de antinutricionales de las semillas de haba mínimamente procesadas en fresco y cocinadas en microondas. El tratamiento UV-C extendió la vida útil de las semillas de haba frescas de 7 a 10 días a $5^{\circ} \mathrm{C}$. Además, el UV-C redujo la concentración de taninos condensados en comparación con las muestras no irradiadas. Así mismo, el cocinado con microondas redujo el contenido de ácido fítico y de taninos condensados.

Teniendo en cuenta que el objetivo general de esta investigación es optimizar varios procesos para desarrollar nuevos alimentos frescos y procesados a partir de variedades nativas de tres especies de legumbres (habas, guisantes y caupí), para estimular el consumo de éstas en la dieta humana diaria, tanto para su consumo en fresco como microondado, se puede decir que con el uso de diversas técnicas de procesamiento mínimo utilizando $\mathrm{NaOCl}$ solo o en combinación con recubrimientos comestibles, o alternativamente con desinfectantes químicos (ASC) o físicos (UV-C), se pueden obtener productos vegetales con alta calidad nutricional y alto contenido de compuestos bioactivos, frescos y listos para consumir. 


\section{LIST OF ABBREVIATIONS}

(B): registered trade Mark

$\mu \mathrm{M}$ : micromolar

$\mu$ mol: micromole

$\lambda \max$ : maximum $\mathrm{w}$ avelength

$\mu \mathrm{g}$ : microgram

$\mu \mathrm{m}$ : micrometer

AA: ascorbic acid

ABTS: 2,2'-azino-bis (3-thylbenzothiazoline-6-sulphonic acid)

AITC: allyl isothiocyanate

ANOVA: analysis of variance

ASTM: American Society for Testing and Materials

AOAC: Association of Official Agricultural Chemists

ASC: acidified sodium chlorite

b.C: before Christ

BITC: benzylisothiocyanate

BOPP: bi-oriented polypropylene

$\mathrm{C}^{*}$ : chroma

C: Celsius

CA: citric acid

CFU: colony forming units

CIE Lab: Lab colour space, International Commission on Illumination $\mathrm{cm}$ : centimeters

CNPq: Council for Scientific and Technological Development (Brazil)

CTRL: control

cvs: cultivars

DAD: diode array detector

DHA: dehydroascorbic acid

DKG: diketogulonic acid

DNA: desoxyribonucleic acid

DPPH: 2,2-Diphenyl-1-picrylhydrazyl free radical

EC: edible coating

EU: European Union 
FAO: Food and Agriculture Organization of the United Nations

FDA: Food and Drug Administration of the United States of America

FRAP: ferric reducing antioxidant power

fw: fresh weight

g: gram

GAE: gallic acid equivalents

GC: gas chromatograph

GMP: good manufacturing practices

GRAS: generally regarded as safe

$\mathrm{H}:$ hue

HPLC: high-performance (pressure) liquid chromatography

IBV: Instituto de Biotecnología Vegetal (Cartagena, Spain)

ISO: International Organization for Standardization

kg: kilogram

$\mathrm{kJ}$ : kilojoules

$\mathrm{L}^{*}$ : lightness

LC: liquid chromatography

log: logarithm

MAGRAMA: Ministerio de Agricultura, Alimentación y Medio Ambiente (Spain)

MAP: modified atmosphere packaging

MP: minimally processed

mg: milligram

min: minute

mL: milliliter

mm: millimeter

mM: millimolar

MW: microwave

NAD: dinucleotide phosphate

NADH: monodehydroascorbate reductase

NADPH: nicotinamida adenina dinucleótido fosfato

$\mathrm{NaOCl}$ : sodium hypoclorite

rpm: revolutions per minute

PCA: plate count modified agar

$\mathrm{pH}$ : potential hydrogen 
RD: Real Decreto (Spain)

RH: relative humidity

ROS: reactive oxygen species

SAR: specific absorption rate

SD: standard deviation

TAC: total antioxidant capacity

TEAC: trolox equivalent antioxidant capacity

TPC: total phenolic content

TPTZ: 2,4,6-tripyridyl-s-triazine

UHPLC: ultra high-performance (pressure) liquid chromatography

UPCT: Universidad Politécnica de Cartagena

UK: United Kingdom

USA: United States of America

UV: UV-C light

var: variety

VRBD: violet red bile dextrose

WHO: World Health Organization

$\mathrm{Y}+\mathrm{M}$ : yeasts and moulds 


\section{INTRODUCTION}




\section{INTRODUCTION}

\section{BOTANICAL AND AGRONOMICAL CHARACTERISTICS OF FABA BEANS, PEAS AND COWPEA}

\subsection{Faba beans}

Faba bean (Vicia faba L.) is a legume originated in western Asia, from where it was spread to Europe, Africa and central Asia by humans. This legume has been known since Neolithic and served as food for the Mediterranean basin. In northern countries, it was later used in the bronze and iron age. It is an annual plant, not very resources demanding and highly productive. It presents wide morphological diversity and the different cultivars show these variations. The seeds $(1-3 \mathrm{~cm}$ diameter) are oblong to ovoid in shape (Figure 1). The color of the seeds ranges from brown to red or green. They are typical plants of warn zones for autumn and winter crops and in cold ones they must be sown in spring (Leguminosae, 2012).

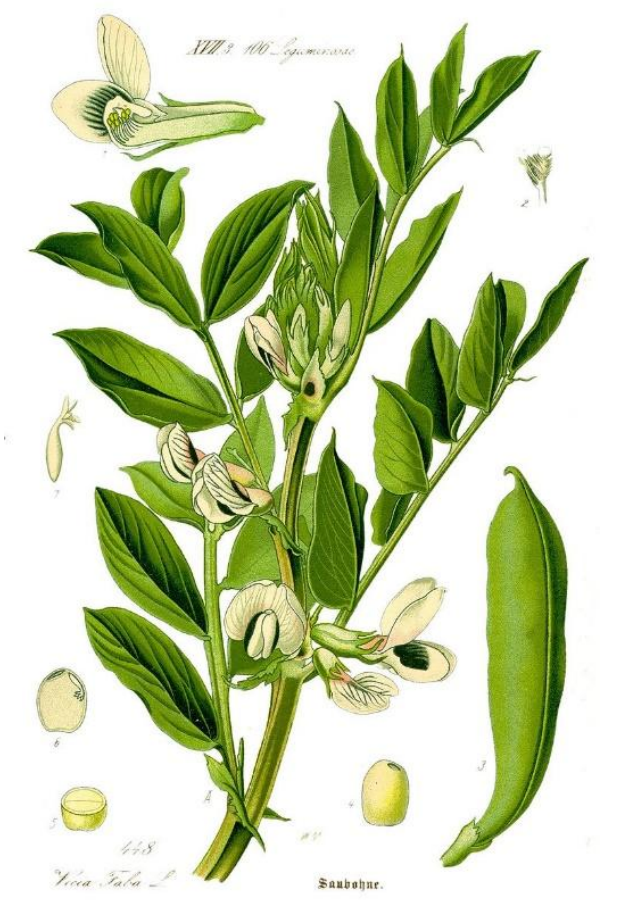

Figure 1. Plant of Vicia faba (in Otto Wilhelm Thomé, Flora von Deutschland, Österreich und der Schweiz, 1885). 
To obtain seeds aimed for fresh consumption, the pods must be harvested at their optimum stage, before they become too lignified. Pods must be around $20 \mathrm{~cm}$ long, 1.5 $\mathrm{cm}$ thick, bright green, fresh in appearance and without very pronounced bumps that would indicate over-maturity (Figure 2). Seeds must be attached to the pod and when separated from each other they must show a green hilium (the presence of black color indicates over-maturity). The seeds must be soft and should have a testa with little amount of fiber (Leguminosae, 2012).

Faba bean is widely grown for its nutritious seeds and pods. As well as being an important food source for humans, the high protein content of faba beans means that it is used for animal feed. The area of production of faba beans in Spain was 22.800 ha in 2019, with a total production of $31.000 \mathrm{t}$ (MAGRAMA, 2019).
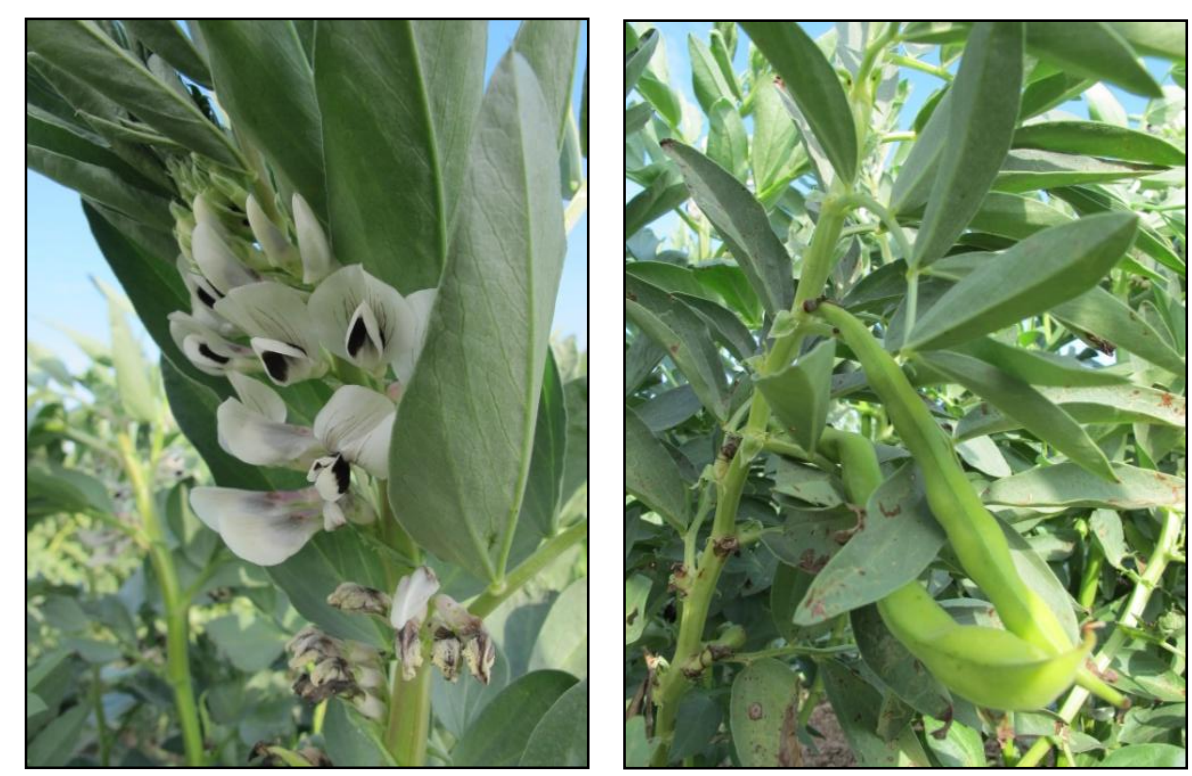

Figure 2. Flowers (left) and pods (right) of Vicia faba

\subsection{Peas}

Peas (Pisun sativum L.), a very polymorphic specie that appeared in the Mediterranean or in the Middle East. Quoted by Columela, the roman empire's main agricultural popularize, there are traces of its non-domesticated consumption by hunter-gatherers from Central Europe during the late Neolithic period. Peas, like many legumes, have the 
ability to fix nitrogen from the air through a symbiotic relationship with bacteria housed in root nodules.

Pisum sativum L. is a climbing annual plant, with pods oblong-obovate, whitish or yellowish when ripe, and with 6-10 globular seeds in each pod (Figure 3), harvested, for fresh consumption at immature physiological stage, when the pods are almost round and with the seeds $70 \%$ of full size. Their quality indices include that peas should be uniformly bright green, fully turgid, clean and free from any damage (Anurag et al., 2016)

The cultivated area of peas in Spain was 144.900 ha in 2018 , with a production of $174.000 \mathrm{t}$ (MAGRAMA, 2019).

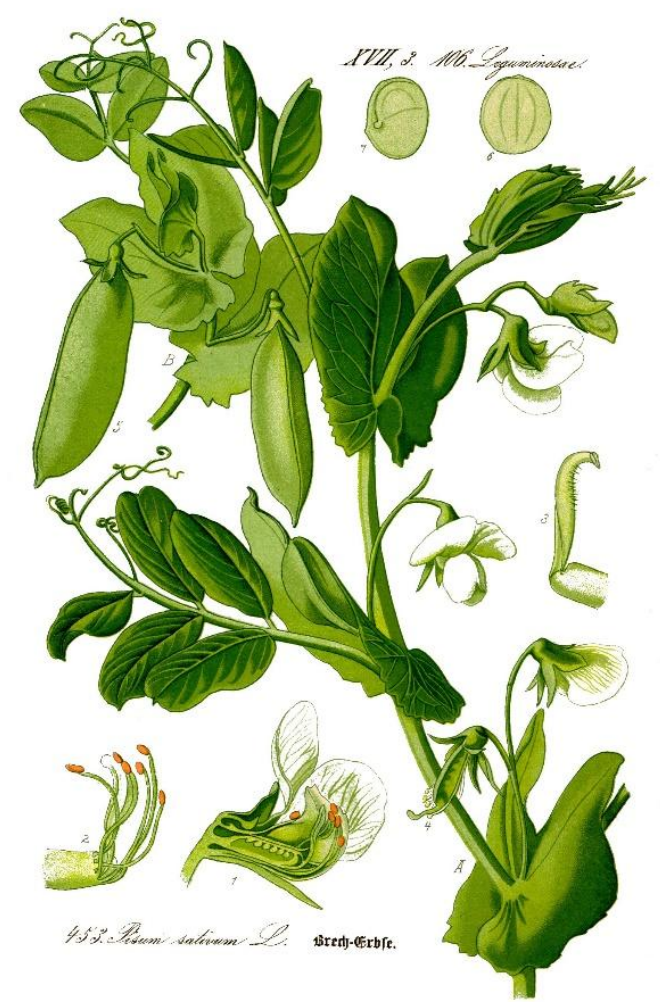

Figure 3. Plant of Pisum sativum (in Otto Wilhelm Thomé, Flora von Deutschland, Österreich und der Schweiz, 1885).

\subsection{Cowpea}

Cowpea (Vigna unguiculata L.) was first domesticated in West Africa 5.000-6.000 years ago and was introduced to Europe around 300 b.C. The Spanish introduced 
cowpea to tropical America in the $17^{\text {th }}$ century and now is grown widely in USA, the Caribbean region and Brazil. Cowpea can be either annual or perennial plant and some types are erected while other are climbing plants (Figure 4). Their fruits are cylindrical seeds with 8 to $30 \mathrm{~cm}$ long pods (in some cases $120 \mathrm{~cm}$ long), pale brown when ripe and bears 8-30 seeds. The seeds are oblong to globose 0.5-1 cm long and can be black, brown, pink or white (Figure 5). The helium is oblong, covered by a white tissue with a blackish edge. It is considered a rustic and resistant plant, mainly due to its tolerance to drought, pests and fungi and not very demanding in fertilizers (Carvalho et al., 2017).

Cowpea can be harvested at three different stages of maturity: a) green snaps, b) greenmature, and c) dry. Depending on temperature and fresh-market demand, peas are ready for harvest 16 to 17 days after bloom (60 to 90 days after planting). Cowpea characteristics vary widely being the grain size the most important single factor influencing price.

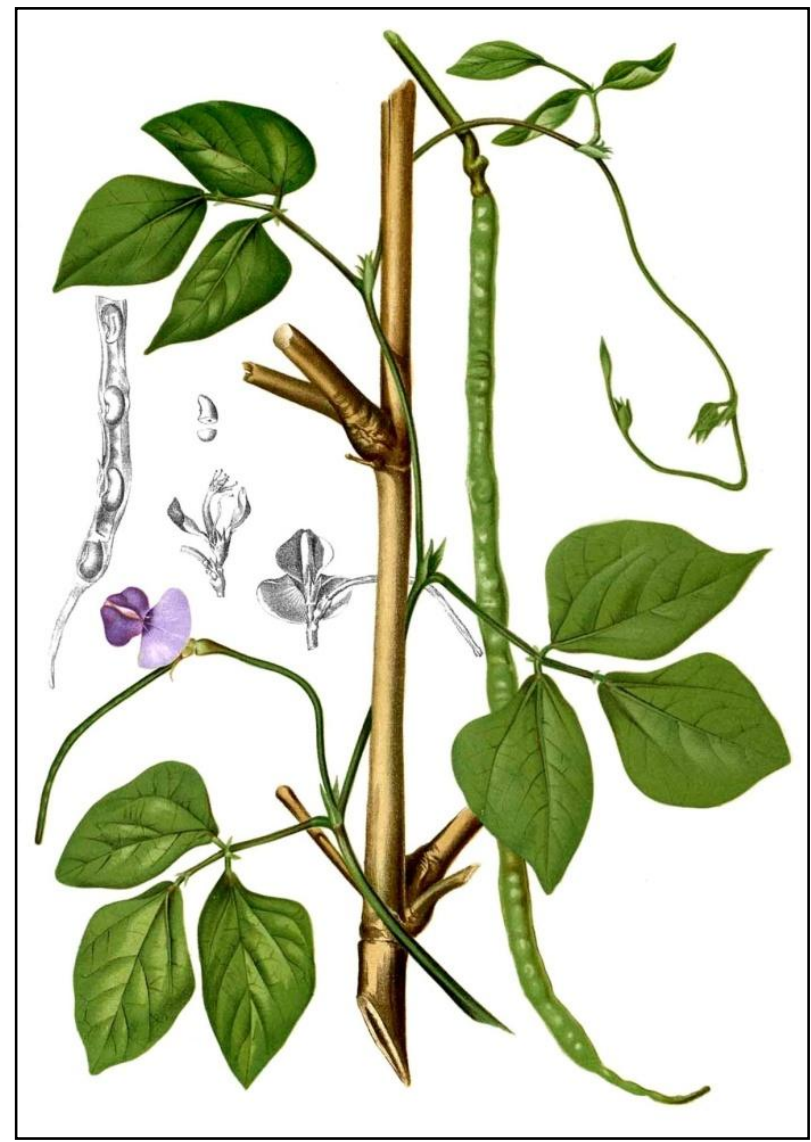

Figure 4. Plant of Vigna unguiculata (http.bibdigital.rjb.csic.esspaindex.php) 

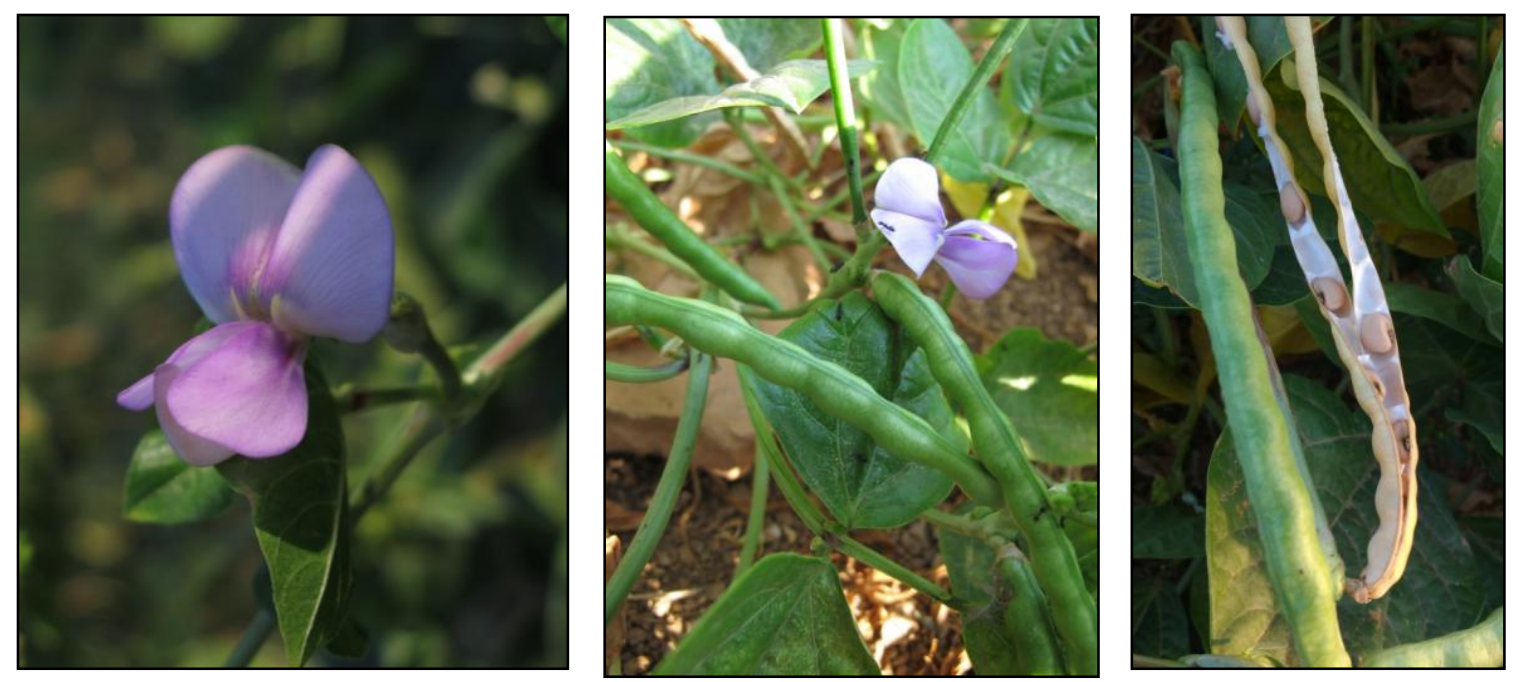

Figure 5. Flowers (left), fresh pods (centre) and dry pods (right) of Vigna unguiculata L.

\section{NUTRITIONAL, BIOACTIVE AND NON-NUTRITIONAL COMPOSITION OF FABA BEANS, PEAS AND COWPEA}

\subsection{Nutritional compounds of legumes}

Legumes have been an essential part of the human diet for centuries. They are quite similar in their composition but they vary in compounds concentration among different pulse species and varieties (Table 1). They are an excellent source of many essential nutrients, including proteins and aminoacids, minerals, fiber, vitamins, slow assimilation carbohydrates and other bioactive compounds, and are low in calories and fat (Dahl et al., 2012; Bouchenak et al., 2013; Singh et al., 2017). They are considered nutritionally recommended considering their composition. For that reason, legumes should be consumed as a part of a healthy diet to combat obesity and to prevent diseases like diabetes, heart disease and cancer (Tharanathan et al., 2003; Trinidad et al., 2010). 
Table 1. Main constituents of faba beans, peas and cowpea. Data obtained from the USDA-ARS (2018).

\begin{tabular}{|c|c|c|c|}
\hline \multirow{2}{*}{ Constituents } & \multicolumn{3}{|c|}{ Content (per $\left.100 \mathrm{~g}^{-1} \mathrm{fw}\right)$} \\
\hline & FABA BEANS & PEAS & COWPEA \\
\hline Energy (kcal) & 50.4 & 90.7 & 116 \\
\hline Water $(g)$ & 85.1 & 76.0 & 80 \\
\hline Proteins $(\mathrm{g})$ & 5.4 & 6.9 & 7.73 \\
\hline Carbohydrates (g) & 4.2 & 11.3 & 20.76 \\
\hline Fibre $(\mathrm{g})$ & 5.1 & 4.9 & 6.5 \\
\hline Fats (g) & 0.2 & 3.6 & 0.53 \\
\hline \multicolumn{4}{|l|}{ Vitamins } \\
\hline Vitamin B1 (mg) & 0.2 & 0.29 & 0.202 \\
\hline Vitamin B2 (mg) & 0.1 & 0.16 & 0.055 \\
\hline Vitamin B3 (mg) & 4.1 & 4.1 & 0.495 \\
\hline Vitamin B6 (mg) & 0.06 & 0.17 & 0.1 \\
\hline Vitamin C (mg) & 24 & 21.9 & 2.5 \\
\hline Vitamin E (mg) & 0.46 & 0.23 & 0.28 \\
\hline Vitamin $\mathrm{K}(\mu \mathrm{g})$ & 43 & 29 & 1.7 \\
\hline \multicolumn{4}{|l|}{ Minerals } \\
\hline $\mathrm{Ca}(\mathrm{mg})$ & 23 & 25.4 & 24 \\
\hline $\mathrm{Fe}(\mathrm{mg})$ & 1.8 & 1.9 & 2.51 \\
\hline $\mathrm{Mg}(\mathrm{mg})$ & 28 & 32.2 & 53 \\
\hline $\mathrm{Zn}(\mathrm{mg})$ & 0.9 & 0.7 & 1.29 \\
\hline $\mathrm{Na}(\mathrm{mg})$ & 18 & 2 & 4 \\
\hline $\mathrm{K}(\mathrm{mg})$ & 210 & 247 & 278 \\
\hline $\mathrm{P}(\mathrm{mg})$ & 98 & 113 & 156 \\
\hline $\mathrm{Mn}(\mu \mathrm{g})$ & 0.22 & 0.35 & 0.475 \\
\hline
\end{tabular}

However, the consumption is limited due to the presence of a series of non-nutritional compounds (Table 2) that could adversely affect the digestibility of proteins and carbohydrates, interfering with mineral bioavailability, inhibiting some enzymes, making nutrients unavailable, producing intestinal gas and can also be toxic in some cases (Bouchenak et al., 2013). These compounds have historically been known as 'antinutritional factors'. Nevertheless, nowadays, there are evidences that they can play 
a beneficial role for human health when they are consumed in the right proportion and frequency (Singh et al., 2017). Therefore, in recent times these compounds are also known as 'non-nutritive' or 'non-nutritional' factors'.

Some of these substances play an important role in plant defence mechanisms or as reserve compounds. They also provide several biological properties including antioxidant, anti-inflammatory, anti-atherogenic and antimicrobial effects (Balasundran et al., 2006). In essence, non-nutritional factors in pulses can potentially have beneficial effects in human health.

Table 2. Main non-nutritive factors of faba beans, peas and cowpea and their effect on humans.

\begin{tabular}{|c|l|l|c|}
\hline $\begin{array}{c}\text { NON- } \\
\text { NUTRITIONAL } \\
\text { FACTOR }\end{array}$ & $\begin{array}{c}\text { PHYSIOLOGYCAL } \\
\text { EFFECTS }\end{array}$ & \multicolumn{1}{|c|}{ BENEFITS } & $\begin{array}{c}\text { CONCENTRATION } \\
\text { (in faba beans) }\end{array}$ \\
\hline SAPONINS & $\begin{array}{l}\text { - Decreases nutrient } \\
\text { absorption } \\
\text { - Depression of growth }\end{array}$ & $\begin{array}{l}\text { - Antimicrobial effect } \\
\text { - Decreases cholesterol } \\
\text { concentration } \\
\text { - Positive effect on the } \\
\text { intestinal tract }\end{array}$ & Savage and Deo (1989) \\
\hline TANNINS & $\begin{array}{l}\text { - Decreases availability } \\
\text { of minerals, proteins } \\
\text { and starch }\end{array}$ & $\begin{array}{l}\text { - Antioxidant activity } \\
\text { - Decreased blood glucose } \\
\text { concentration } \\
\text { - Antimicrobial effect }\end{array}$ & $\begin{array}{c}5 \text { - } 10 \mathrm{~g} \mathrm{~kg}^{-1} \\
\text { Vilariño et al. (2009) }\end{array}$ \\
\hline RAFFINOSE & $\begin{array}{l}\text { - Gas formation in the } \\
\text { colon }\end{array}$ & $\begin{array}{l}\text { - Prebiotic effect } \\
\text { - Increased solubility of } \\
\text { minerals }\end{array}$ & Goyoaga et al. (2011) \\
\hline PHYTIC ACID & $\begin{array}{l}\text { - Decreases availability } \\
\text { of minerals, proteins } \\
\text { and starch }\end{array}$ & $\begin{array}{l}\text { - Toxic metal bonding } \\
\text { - Delayed glycemic } \\
\text { response }\end{array}$ & Adamidou et al. (2011) \\
\hline
\end{tabular}

\subsection{Main nutritive and bioactive compounds of faba beans, peas and cowpea}

\subsubsection{Vitamin C}

Vitamin $\mathrm{C}$ or ascorbic acid (AA) is one of the simplest structured vitamins, as it is the lactone of an acid-sugar. Ascorbic acid is needed in the diet of a few vertebrates, including humans. This is due to the lack of the enzyme flavoenzyme L-guluno-1,4- 
lactone oxidase (Davey et al., 2000; Nelson et al., 2005). Deficiencies of AA are responsible of scurvy.

It is a potent reducer, it is stable in dry form but in solution it easily loses hydrogen atoms and transforms into dehydroascorbic acid (DHA), which also possesses vitamin C activity. However, vitamin activity is lost when the laconic ring of dehydroascorbic acid is hydrolyzed to 2,3-diketogulonic acid (2,3-DKG) (Figures 5 and 6). Various factors such as concentration, temperature, light, $\mathrm{pH}$, etc., influence on the oxidation of L-AA and ADHA hydrolysis. ADHA and specially 2,3-DKG acid have very limited antiscorbutic activity and in some cases do not even have it. L-AA, however, has three types of biological activity: enzyme co-factor, free radical neutralizer, and as a donor/catcher in electron transport in plasma membranes or chloroplasts (Davey et al., 2000). It is the main antioxidant present in plant cells, fulfilling a vital function in the elimination of reactive oxygen species (ROS) by means of both enzymatic and nonenzymatic detoxification.

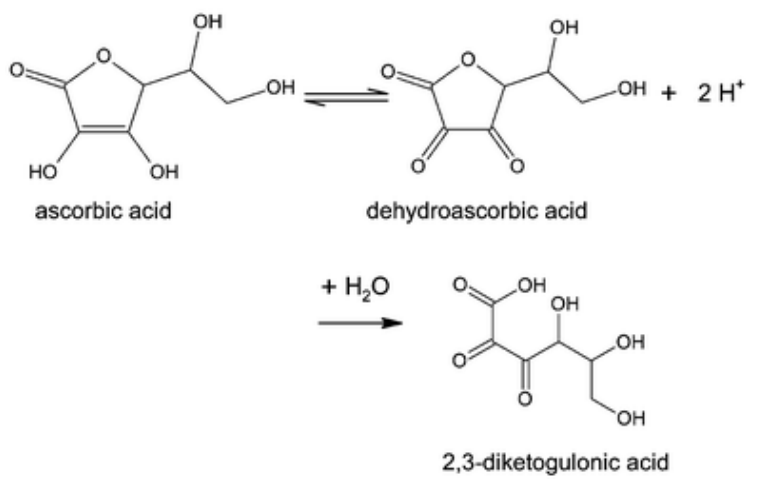

Figure 6. Chemical formulations of ascorbic acid, dehydroascorbic acid and 2,3-diketogulonic acidCITA?

Large amounts of ascorbic acid can be found in vegetable tissues, being one of the major vitamins in beans, peas and cowpea. 


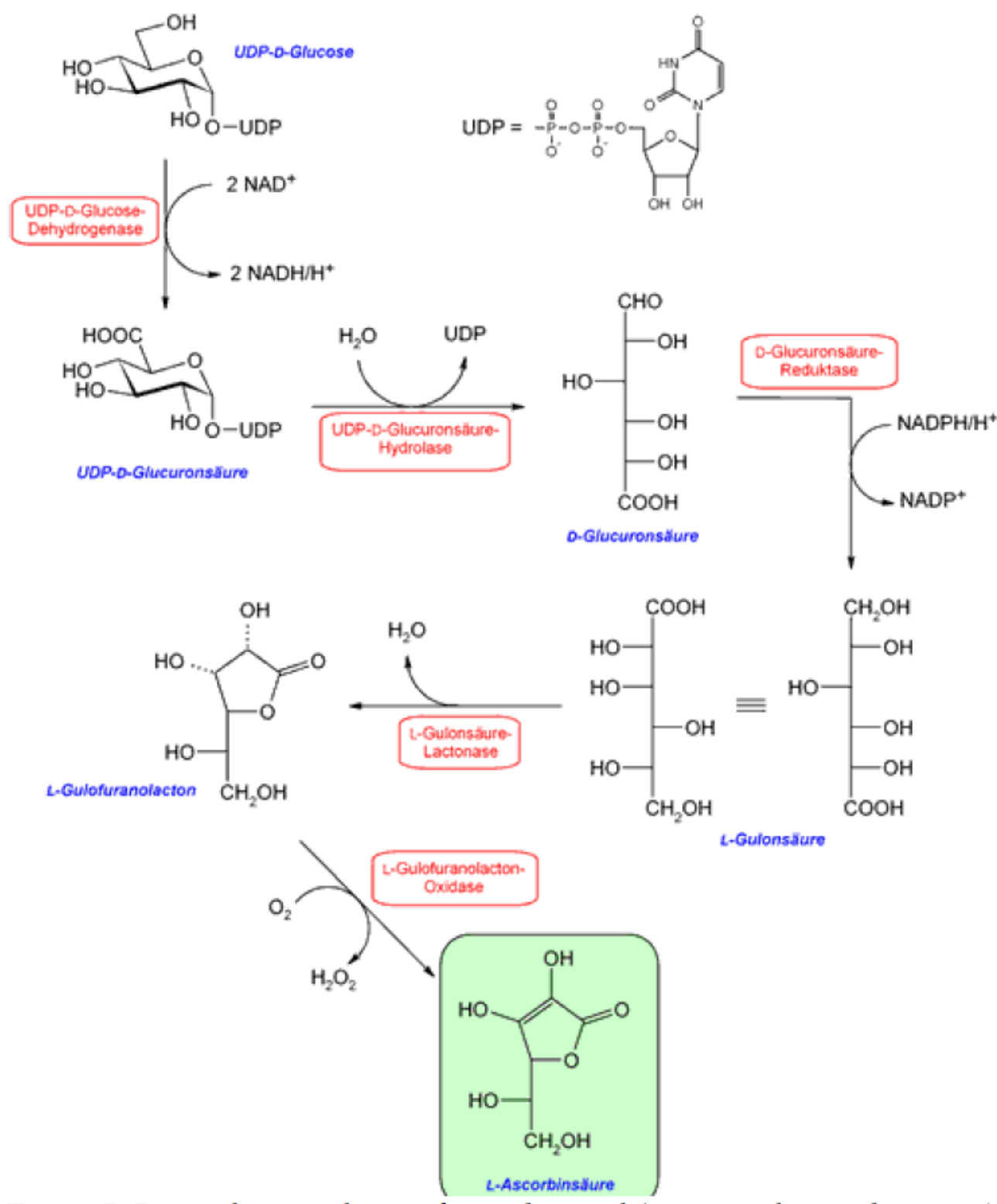

Figure 7. Biosynthetic pathway of ascorbic acid (www. acidoascorbico.com)

\subsubsection{Phenolic compounds}

Phenolic compounds or polyphenols constitute a broad group of chemical substances characterized by having a benzene ring with one or more hydroxyl groups. In nature, phenols are found together with sugars and organic acids (Cartea et al., 2011). Therefore, the most common way to find them in nature is in the form of glycosides (Martínez-Valverde et al., 2000). Concentration of some phenolic compounds in immature seeds of faba bean, peas and cowpea is shown in Tables 3, 4 and 5.

Its main functions in plant cells are to act as essential metabolites for the growth and reproduction of plants, and as a defense mechanism against pathogens. Phenolic 
compounds have a wide effect in human health as these can contribute towards the antioxidant activities and they have many bioactive properties such as antimicrobial, anticancer, anti-inflammatory and reduction in heart and brain diseases (Chaieb et al., 2011; Singh et al., 2017). Phenolic compounds are related to the sensory quality of fruit and vegetables, as their oxidation causes enzymatic browning in food, a phenomenon of great importance as a quality parameter. Likewise, a type of phenolic compounds, condensed tannins, is responsible for the astringency of many vegetable foods (Martínez-Valverde et al., 2000).

Phenolic acids and their derivate flavanols, flavan-3-ols, anthocyanins, and condensed tannins are the main polyphenol compounds present in legumes. Flavonoids, phenolic acids and procyanidins are the dominant phenolic compounds present in peas and faba beans (Zhang et al., 2015).

Phenolic compounds can be grouped, depending on their basic chemical structure, into flavonoids and non-flavonoids. The former are characterized by sharing a basic structure of two benzene rings linked by a heterocyclic ring of pyrone $\mathrm{C}$, (flavonols, flavones, falvan-3-ols, anthocyanidins, flavanones, isoflavones and others), and the latter by being a more heterogeneous group (phenolics acids, hydroxycinnamates, stilbenes and others) (Tomás-Barberán et al., 2003). The biosynthetic pathway of some phenolic compounds is showed in Figure 8. The most important nutritional factors are briefly described below (Martínez-Valverde et al., 2000; Crozier et al., 2006; Cartea et al., 2011):

- Phenols and phenolic acids: the simple phenols (phenol, crucible, thymol, resorcinol) are widely distributed among all plant species, as are phenolic acids (galic, vanillinic), which are abundant in upper plants and ferns. Phenolics acids have one carboxylic acid group and may be present in plants in free and bound forms.

- Cynamic acids and coumarins: cinamic acids (caffeic, p-coumaric and synaptic) are rarely found free. On the other hand, coumarins are generally found in the form of glycosides.

- Lignans: metabolites of low molecular weight, formed by 2 units of phenylpropane linked by a hydrogen bridge. 
- Flavonoids: they are the most important group within this classification, being the polyphenols most distributed in plants. They have a structure of 15 carbon atoms (C6-C3-C6). The aromatic ring $\mathrm{A}$ is derived from the acetate/malonate pathway, and ring $\mathrm{B}$ is derived from phenylalanine through the shikimate pathway. Variations in substitution patterns to ring $\mathrm{C}$ result in 13 flavonoid classes, being the most important flavonols, flavones, isoflavones, flavanones, flavanols (also called flavan-3-ols) and anthocyanidins or anthocyanins.

- Tannins: water-soluble compounds with a molecular weight between 500-3000 $\mathrm{Da}$, able to bind proteins and other macromolecules. They can be classified into two groups: hydrolyzable tannins and non-hydrolizable or condensed tannins (also known as protoanthocyanidins).

Table 3. Concentration of some phenolic compounds ( $\left.\mathrm{mg} \mathrm{kg}^{-1} \mathrm{fw}\right)$ in immature seeds of faba bean (Baginsky et al., 2013).

\begin{tabular}{|l|c|}
\hline \multicolumn{1}{|c|}{ COMPOUND } & $\begin{array}{c}\text { CONCENTRATION } \\
\left(\mathrm{mg} \mathrm{kg}^{-1} \mathrm{fw}\right)\end{array}$ \\
\hline Prodelphinidin dimer & 199.01 \\
\hline (+)-Catechin & 643.90 \\
\hline Procyanidin dimer & 78.41 \\
\hline Procyanidin trimer & 146.52 \\
\hline (-)-Epicatechin & 653.67 \\
\hline Procyanidin dimer & 195.41 \\
\hline Total proanthocyanidins & $\mathbf{1 9 1 6 . 9 6}$ \\
\hline Quercetin 3-O-rutinoside & 56.91 \\
\hline Apigenin 7-O-galactoside & 20.66 \\
\hline Apigenin 7-O-galactoside & 31.13 \\
\hline Quercetin 3-O-galactoside & 82.12 \\
\hline Myricetin 3-O-glucoside & 25.28 \\
\hline Quercetin derivative & 19.06 \\
\hline Quercetin 3-O-glucoside & 22.73 \\
\hline Myricetin & 119.49 \\
\hline Total flavonols + flavones & $\mathbf{3 7 7 . 3 8}$ \\
\hline
\end{tabular}


Table 4. Concentration of some phenolic compounds $\left(\mathrm{mg} \mathrm{kg}^{-1} \mathrm{fw}\right)$ in immature seeds of peas (Stanisavljević et al., 2015).

\begin{tabular}{|c|c|}
\hline COMPOUND & $\begin{array}{l}\text { CONCENTRATION } \\
\left(\mathrm{mg} \mathrm{kg}^{-1} \mathrm{fw}\right)\end{array}$ \\
\hline Gallic acid & 1.96 \\
\hline Protocatechuic acid & 127.22 \\
\hline Gentisic acid & 5.01 \\
\hline Chlorogenic acid & 1.59 \\
\hline Cafeic acid & 2.49 \\
\hline p-Hydroxyphenylacetic acid & 3.49 \\
\hline p-Coumaric acid & 2.14 \\
\hline Ferulic acid & 5.33 \\
\hline Sinapic acid & 4.56 \\
\hline Syringic acid & 1.87 \\
\hline Rosmarinic acid & 1.81 \\
\hline Catechin & 3.08 \\
\hline Epicatechin & 14.59 \\
\hline Catechin gallate & 2.69 \\
\hline Epigallocatechin & 5.96 \\
\hline Quercetin & 13.66 \\
\hline Rutin & 11.51 \\
\hline Kaempferol & 6.49 \\
\hline Galangin & 4.19 \\
\hline Morin & 4.93 \\
\hline Luteolin & 9.40 \\
\hline Apigenin & 3.62 \\
\hline Naringin & 1.68 \\
\hline Hesperetin & 3.15 \\
\hline Pinocembrin & 3.44 \\
\hline
\end{tabular}


Table 5. Concentration of some Phenolic compounds $\left(\mu \mathrm{g} \mathrm{g}^{-1} \mathrm{fw}\right)$ in immature seeds of cowpea (Adelakun et al., 2017).

\begin{tabular}{|l|c|}
\hline COMPOUND & CONCENTRATION $\left(\mu \mathrm{g} \mathrm{g}^{-1} \mathrm{fw}\right)$ \\
\hline Gallic acid & 378.00 \\
\hline Protocatechuic acid & 493.60 \\
\hline 4-hydroxybenzoic acid & 81.60 \\
\hline Vanillic acid & 13.39 \\
\hline Caffeic acid & 11.90 \\
\hline Syringic acid & 920.40 \\
\hline p-coumaric acid & 5.20 \\
\hline Ferulic acid & 3.80 \\
\hline Quercetin dihydrate & 442.80 \\
\hline Hesperidin & 617.40 \\
\hline Naringin & 403.30 \\
\hline Fisetin & \\
\hline Kaempferol & 184.80 \\
\hline Kaemferol glucoside & 430.30 \\
\hline Taxifolin & $8,799.00$ \\
\hline Catechin & $1,545.20$ \\
\hline Epicatechin & $7,031.90$ \\
\hline Tannic acid & \\
\hline
\end{tabular}

\subsubsection{Antioxidant compounds}

Active molecules containing $\mathrm{O}_{2}$ are called reactive oxygen species (ROS). The ROS include oxygen ion $\left(\mathrm{O}_{2}\right)$, free radicals $\left(\mathrm{O}_{2},-\mathrm{OH}\right.$, NO-, etc.) and peroxides $\left(\mathrm{H}_{2} \mathrm{O}\right.$, ONOO, etc.). They have great reactive capacity due to the presence of odd valence membrane electrons. ROS are formed as by-products of the metabolism of $\mathrm{O}_{2}$ and have an important role in cell signaling and homeostasis (Taverne et al., 2013). However, under stress, whether exogenous (exposure to heat, ultraviolet light, $\mathrm{O}_{3}$, contaminants, additives, etc.) or endogenous (mono-electronics reduction of $\mathrm{O}_{2}$, auto-oxidation of $\mathrm{C}$, catalytic activation of numerous enzymes, etc.), the levels of ROS can increase greatly and cause accumulated damage to the cellular structure, which is known as oxidative stress (Devasagayam et al., 2004). 
Antioxidants are compounds that, at low concentrations compared to the substrate, delay or prevent oxidation during oxidative stress (Devasagayam et al., 2004). According to their origin, these compounds are classified as enzymatic and nonenzymatic (Figure 9). Total antioxidant capacity (TAC) is influenced by physiological factors (such as maturity, senescence) and technological factors such as storage or processing conditions (Tarazona-Díaz, 2011). Biosynthetic pathway of some antioxidant enzymes are shown in Figure 10.

Diets rich in fruits and vegetables have been shown to reduce the risk of cardiovascular and other chronic and degenerative diseases associated with oxidative damage to cells (Dragsted, 2003; Balasundram et al., 2006). This protective effect of fruit and vegetable consumption has been associated to the presence of antioxidants such as polyphenols and vitamin $\mathrm{C}$ in their composition (Scalbert et al., 2005). 


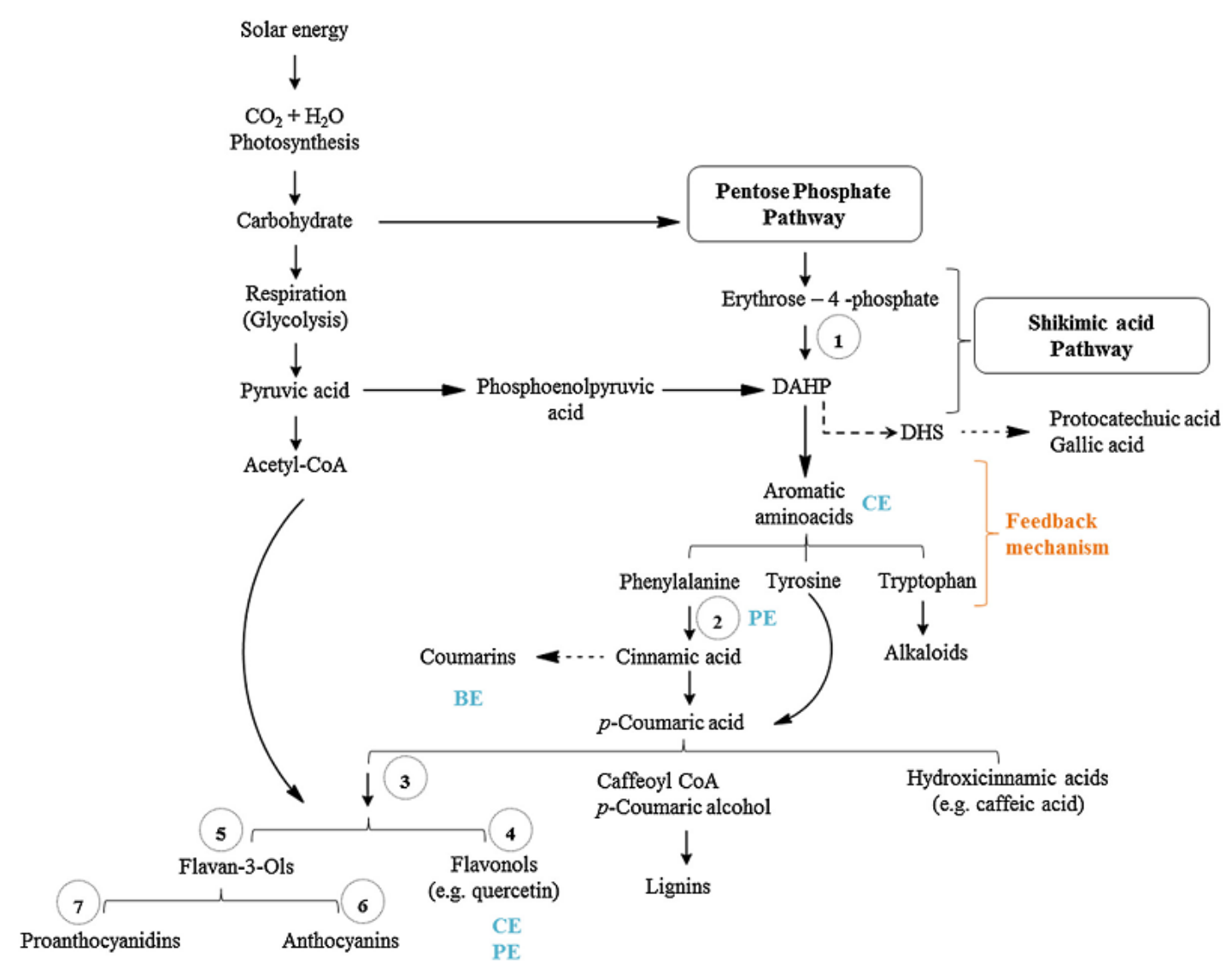

Figure 8 . Biosynthetic pathway of some phenolic compounds and the influence of elicitationCO2_carbon dioxide; H2O-water; Acetil-CoA-AcetilCoenzyme A; DAHP-3-Deoxy-O-arabino-heptulosonate phosphate; DHS-3-Dehydroquinate; BE-biological elicitation; $\mathrm{CE}$ - chemical elicitation; PE-Physical elicitation; Enzymes involved in the biosynthesis are marked with rounded dashed black forms: 1-DAHP synthase (3-Deoxy-O-arabino-heptulosonate phosphate synthase); 2-PAL (Phenylalanine ammonia-lyase); 3-CHS (Chalcones synthase), CHI (Chalcones isomerase), $\mathrm{F3H}$ (Flavanone-3-hydroxylase); 4-FLS(Flavonol synthase); 5-LAR (Leucoanthocyanidin reductase); 6-LDOX (Leucoanthocyanidin dioxygenase). (Dias et al., 2016) 


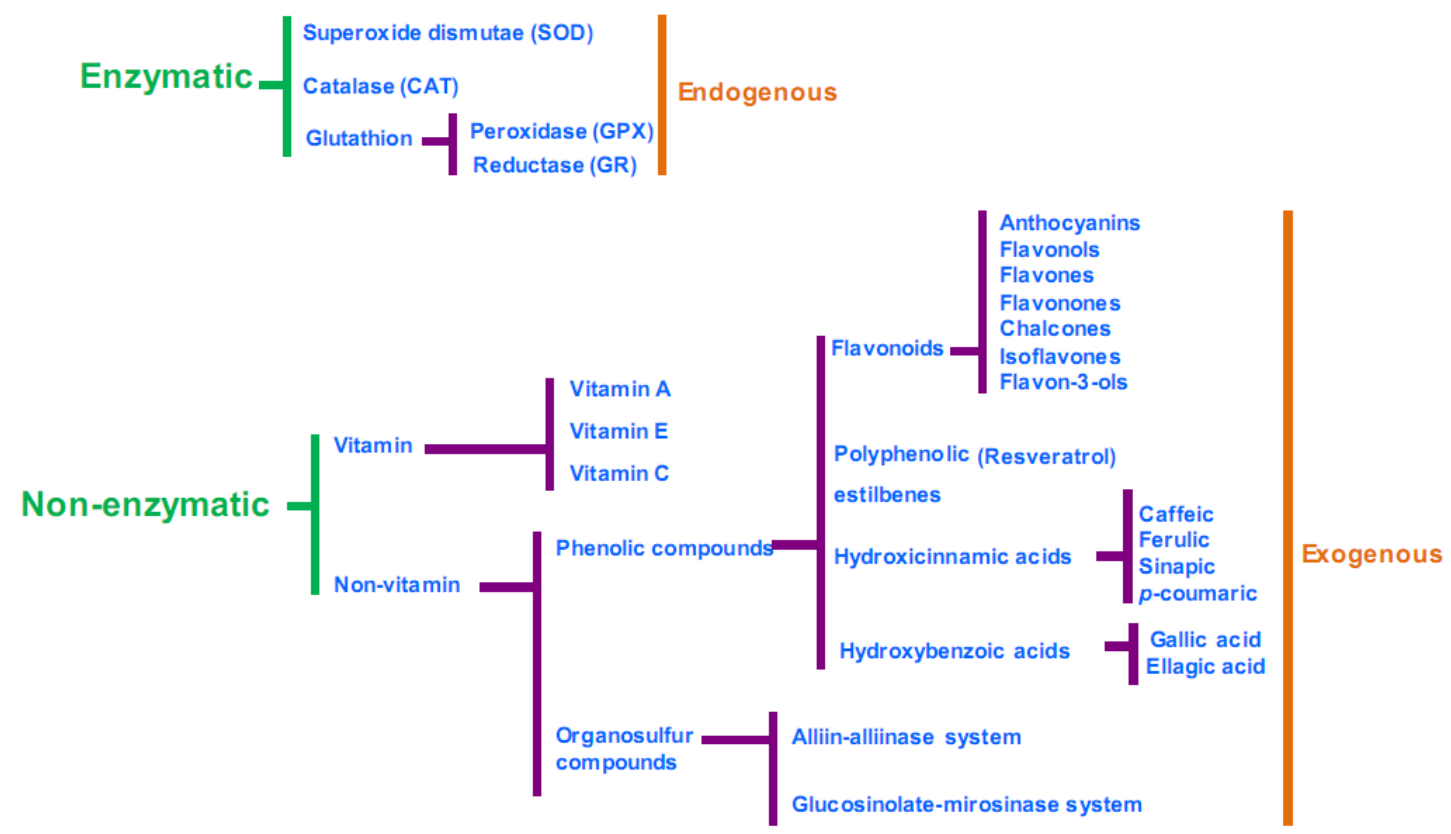

Figure 9. Antioxydant compounds classification (Artés-Hernández et al., 2009).

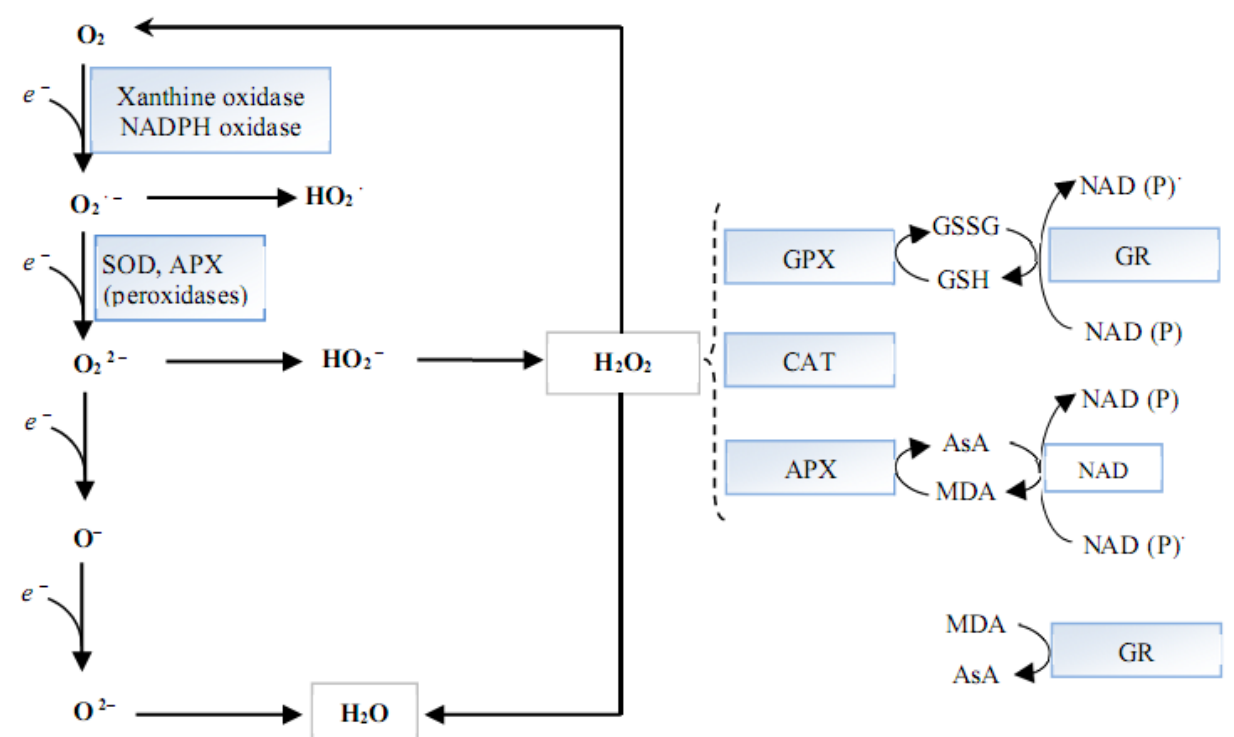

Figure 10 Antioxidant enzymes pathways (Gärtner and Wese, 1986). AsA: ascorbate; APX: ascorbate peroxidase; CAT: catalase; GPX: guaiacol peroxidase; GR: gluaiacol reductase; GSH: glutathione; GSSG: glutathione disulfide; MDA: monodehydroascorbate; NAD: nicotinamide adenine dinucleotide; NADPH: nicotinamide adenine dinucleotide phosphate; SOD: superoxide dismutase. 


\subsection{Main non-nutritional factors in legumes}

\subsubsection{Condensed tannins}

Tannins are water-soluble polyphenolic compounds with high molecular weight (500$3000 \mathrm{Da}$ ). They are associated with plant defense mechanism against mammalian herbivores, birds and insects (Hassanpour et al., 2011) due to its astringent property, and against bacteria, viruses and fungi, because its ability to inhibit enzymes. In addition, they participate in the nodulation of legumes, generating important quantities of nitrogen (Shirley et al., 1996).

Depending on their chemical structure and properties, tannins can be divided into two main groups: hydrolysable and condensed tannins (Figure 11), in which each form has different nutritional and toxic effects (Nikmaram et al., 2017). The hydrolysable type of tannins is prone to hydrolysis during the digestion process. They are molecules which contain a carbohydrate, generally D-glucose, as a central core. These carbohydrates are esterified with phenolic groups. Hydrolysable tannins are usually found in lower concentration in plants than condensed tannins (Hassanpour et al., 2011).

In contrast, condensed type of tannins is more resistant to hydrolysis; for that, it is neither hydrolyzed nor absorbed during digestion. They are the most common type of tannins found in legumes (Barry and MacNabb, 1999). The first researchers that detect them in seed of faba beans were Barker and Morris (1968). Condensed tannins consist of flavonoid units (flavan-3-ol and/or flavan-3,4-diol) linked by carbon-carbon bonds. In presence of heat and acid medium, they release anthocyanidins, hence they are also called proanthocyanidins. 

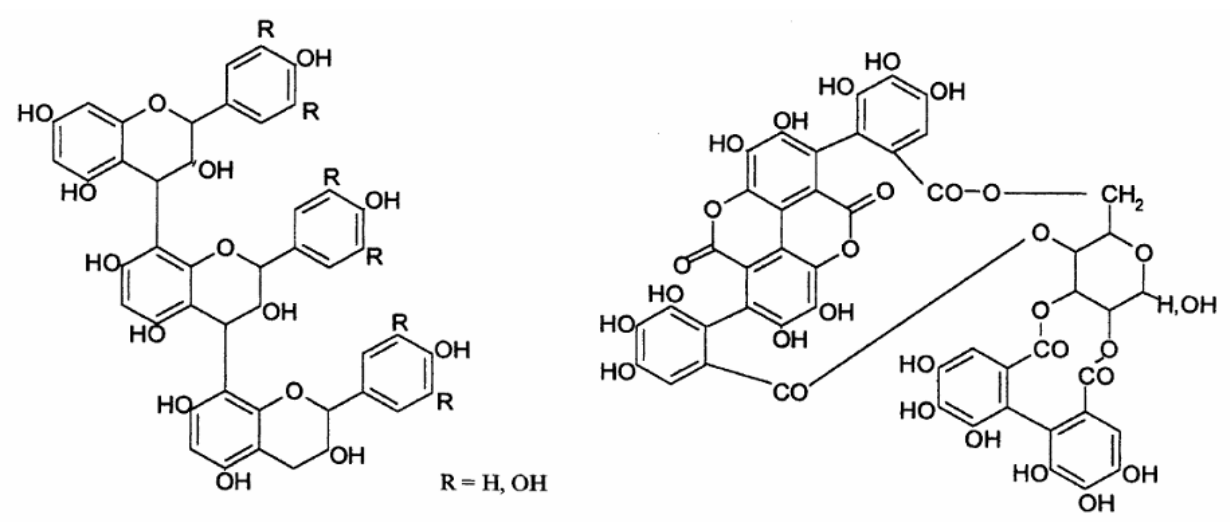

Figure 11. Chemical structure of condensed tannins (left) and hydrolysable tannins (right) (Hassanpour et al., 2011).

Condensed tannins have a variety of chemical structures affecting their physical and biological properties. Its biological effects are specially related to its polymerization degree, and the number of phenolic groups present in the molecule is the basis of its binding to proteins, carbohydrates, metal cations and free radicals (Santos-Buelga and Scalbert, 2000).

The anti-nutritional effects of tannins include interference with digestion by binding to proteins or minerals. The tannin-protein complex (Figure 12) is the consequence of multiple hydrogen bonds forming between the hydroxyl group of tannins and the carbonyl group of proteins (Raes et al., 2014). However, because of this, they also have therapeutic or preventive properties against gastrointestinal diseases due to the binding with proteins of the intestinal mucous membrane, forming a protective film (Saito et al., 1998). Tannins interfere with the assimilation of disaccharides by a strong inhibition of maltases, sacarases and lactases. They also inhibit the active transport of glucose through the intestine and reduce digestion and absorption of starch. This leads to a reduction in blood glucose and an increase in insulin, being useful as a treatment for diabetes and obesity control (Thompson et al., 1993).

Protocyanidines can cause a deficiency of $\mathrm{Fe}^{+2}$, sometimes triggering anemia. They also reduce the bioavailability of $\mathrm{Ca}^{+2}, \mathrm{Mg}^{+2}$ and $\mathrm{Zn}^{+2}$, while having a little affinity with $\mathrm{Cu}^{+3}$ increase their bioavailability. Thanks to the reducing of the condensed tannins, oxidative damage is avoided and anti-cancer and antimutagenic activity is developed (Santos-Buelga and Scalbert, 2000). In addition, condensed tannins are antimicrobial 
agents that act against a large number of bacteria, viruses and fungi (Sakanaka, et al., 1990). On the other hand, it has also been observed that regular ingestion of large amounts of tannins increases the risk of developing tumor diseases due to irritation and cellular damage (Singleton, 1981).

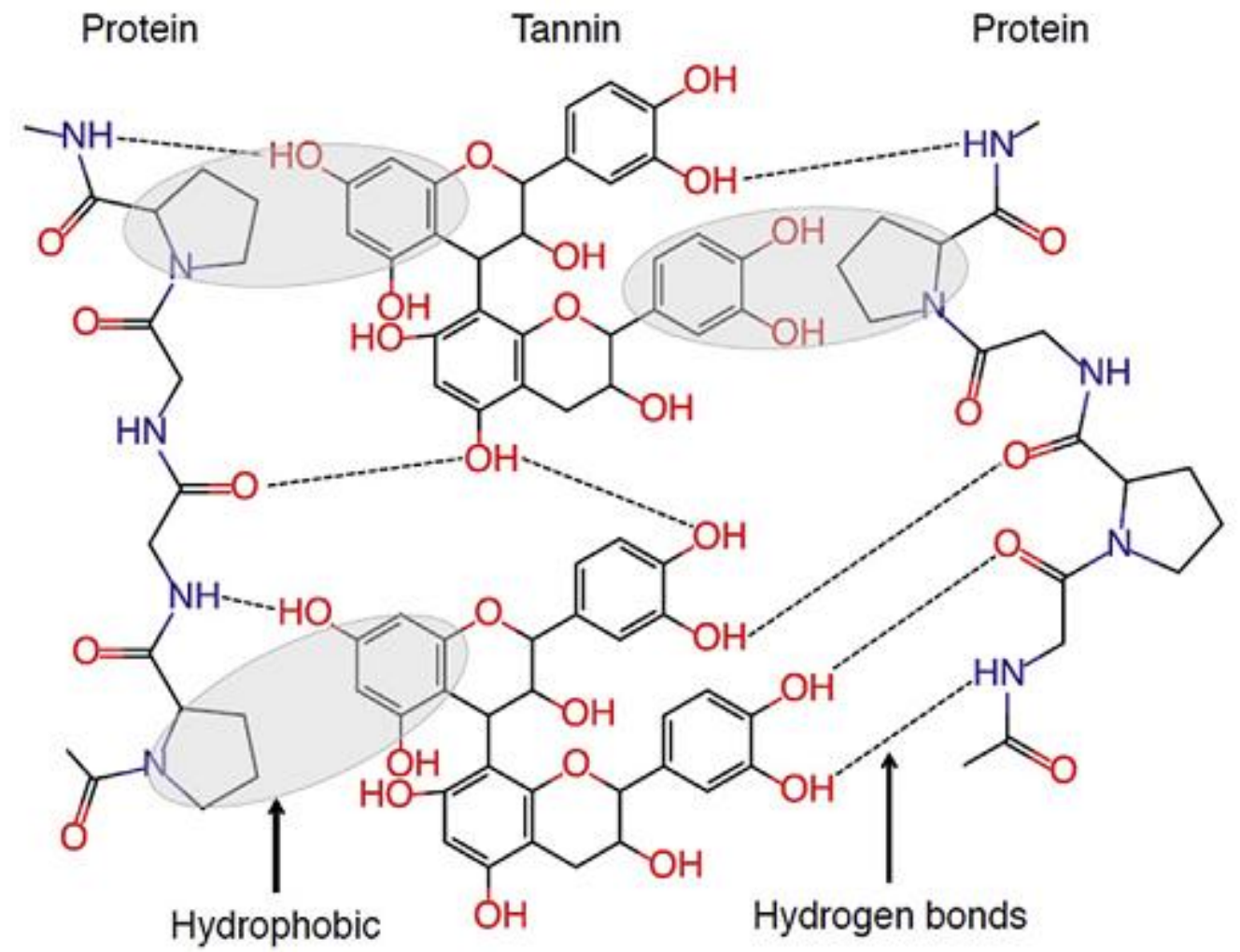

Figure 12. Interaction of tannin with protein (Nikmaram et al., 2017)

\subsubsection{Saponins}

Saponins are secondary metabolites which are widely distributed in the plant kingdom. They derive their name from their ability to form stable soap-like foams in aqueous solutions and they have been commonly used for centuries as household detergent due to its amphiphilic nature with the presence of a lipid-soluble aglycone and water-soluble chain in their structure (Guclu-Ustundag and Mazza, 2007).

Saponins may be considered a part of plants' defense systems since they act as a chemical barrier countering pathogens and herbivores (Cheok et al., 2014). Many of them are known to be amtimicrobial, to inhibit mould and to protect plants from insect attack (Francis et al., 2002). They are a very heterogeneous group of amphipathic 
glycosides. They consisted of non-polar aglycones (triterpenoid or steroid) attached to one or more polar monosaccharide chains (hexose, pentose or uronic acid) (Nikmaram et al., 2017). The common sugars in saccharide chains are D-glucose, D-galactose, Larabinose, D-xylose, L-rhamnose and D-lucoronic acid (Du et al., 2002). Saponins have a polycyclic ring system in their aglycone (either 27 carbon sterol or 30 carbon triterpene). The sugar moiety in a saponin molecule is attached to aglycone at one or two glycosylation sites by glycosidic linkage. Saponins are glycosylated compounds or glycosides that are divided into three main groups according to the carbon skeleton of non-polar aglycone region: triterpenoidal glycosides, steroidal glycosides and steroidalkaloidal glycosides. Saponins that have been characterized and commonly identified in pulses are the triterpene glycosides (Barakat et al., 2015).

They are categorized as monodesmosides (having a single sugar chain linked to carbon3 of the aglycone) and bidesmosides (having two sugar chains separately linked to carbon-3 and carbon-22 of aglycone) (Lásztity et al., 1998). These compounds show a variation in their structure among different plant species, depending upon the type and composition of the aglycone and saccharide chains. Saponins are categorized into A, B and E group according to their aglycone structures (Wu and Kang, 2011) (Figure 13). The group A have sapogenol A as the triterpenoid moiety with a hydroxyl group at carbon-21 and two saccharide chains attached to carbon-3 and carbon-22.

The group B contains sapogenol B in their structure and differs from group A by having a hydrogen atom at carbon-21 of its aglycone. They are monodesmosides with one glycoyl group attached at carbon-3 position of aglycone and are named as soyasaponin I (Bb), II (Bc), III (Bb'), IV (Bc') and V (Ba) (Wu and Kang, 2011). Group B saponins with 2,3-dihydro-2,5-dihydroxy-6-methyl-4H-pyran-4-one (DDMP) group at carbon-22 are denoted as the DDMP saponins. DDMP saponins are named as soyasaponin $\alpha \mathrm{a}, \alpha \mathrm{g}$, $\beta \mathrm{a}, \beta \mathrm{g}$, $\gamma \mathrm{a}$ and $\gamma \mathrm{g}$ (Berhow et al., 2002). DDMP saponins are unstable under commonly used food processing conditions such as high temperature, acidic and alkaline $\mathrm{pH}$ and subsequently get converted into saponin B after losing their DDMP moiety (Heng et al., 2006). Group E are monodesmosides that resemble group B with a single saccharide chain attached to carbon-3 of triterpenoid moiety, but differ from saponins B by having a carbonyl group at carbon-22 of aglycone (Wu and Kang, 2011). 
Saponins are commonly identified in the seeds of edible legumes, and have a significant importance, mainly because of their biological activities. Several researchers have documented that legume seeds are the main saponin containing foods in the human diet (Price et al., 1986; Khalil and El-Adawy, 1994; Lásztity et al., 1998). Two kinds of saponins are identified in faba beans and peas, soyasaponin I and soyasaponin $\beta \mathrm{g}$ (Ha et al., 2014; Reim and Rohn 2015; Singh et al., 2017). In cowpea, in addition to this two types of saponins, have also been identified soyasaponin II and soyasaponin $\alpha \mathrm{g}$ (Ha et al., 2014).

The ingestion of large amounts of saponins can cause irritation of the intestinal epithelium, but they do enter to the bloodstream through lesions, and can cause hepatic damage, hemolysis, respiratory failure and coma. Saponins are also capable of hydrolyzing other cells, such as those in the intestinal mucous membrane, interfering with the absorption of nutrients. In addition, they inhibit metabolic and digestive enzymes such as proteases, amylases or lipases (Price et al., 1987; Thompson, 1993).

However, small concentrations of saponins absorbed by the intestine exert a positive effect on the intestinal tract. Their biological effects have been attributed as they can enhance the permeability of intestinal mucosal cells, inhibit the transport of active mucosal and facilitate the uptake of substances that are normally not absorbed (Couto et al., 2015). Presence of saponins in food has other beneficial effects on protein digestion, cholesterol metabolism and immune and nervous systems (Francis et al., 2002). Also, they decreased bloods lipids and lowered blood glucose response, have importance in reducing the risk of cancer and contribute towards the antioxidant and antiinflammatory properties (Singh et al., 2017).

\subsubsection{Raffinose}

The oligosaccharides of the raffinose family (RFO): raffinose, stachyose and verbascous, are $\alpha$-galactosides that are within the group of galactosyl sucrose oligosaccharides (Figure 15). These non-reducing sugars of low molecular weight soluble in water and solutions of water-alcohol, are reserve compounds present in varying quantities in organs and in seeds of numerous plants, including leguminous plants. These oligosaccharides are also called 'flatulence factors' because when 
fermented by intestinal microflora, release considerable amounts of gases (Kadlec et al., 2000a).

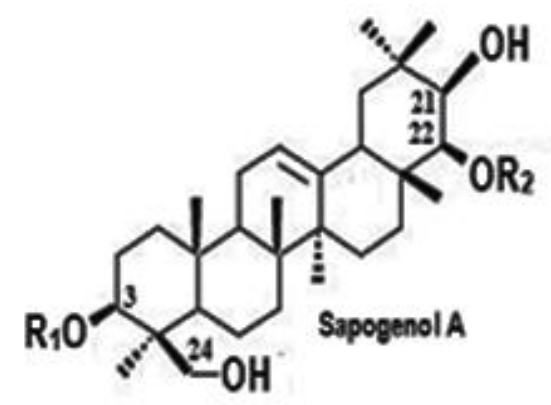

Group A saponins
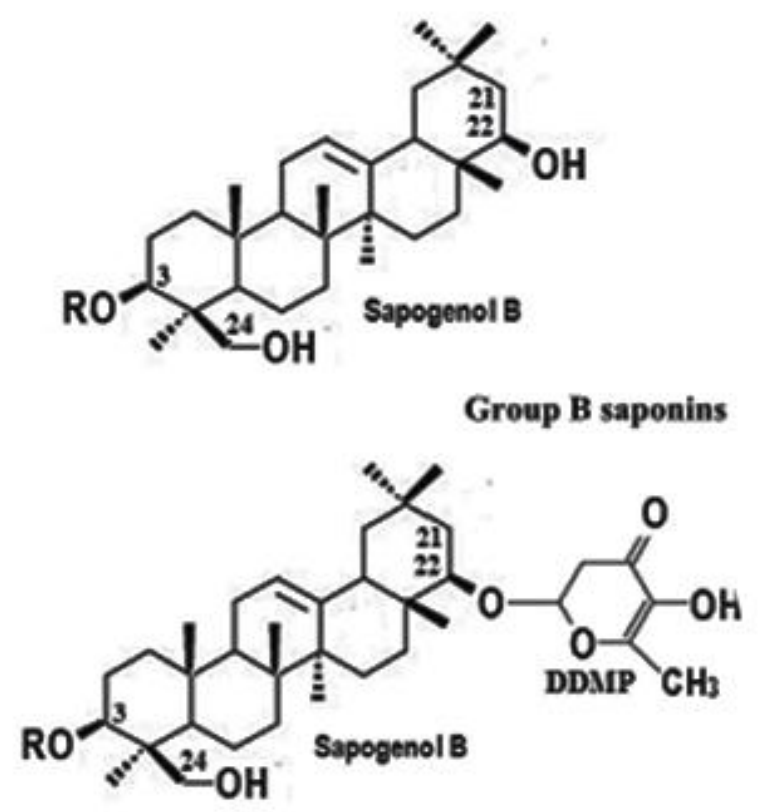

DDMP saponins

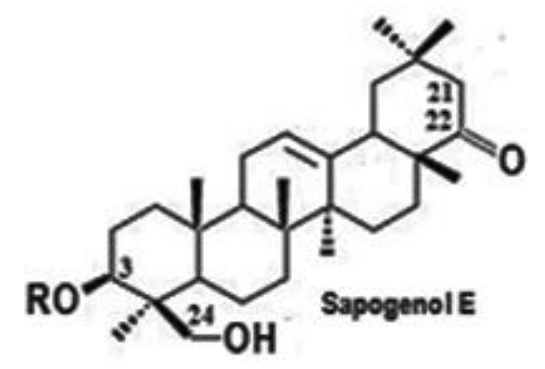

Figure 13. Chemical structures of groups $A, B, E$ and DDMP saponins (glcUA: $\beta$-DGlucuronopyranosyl, gal: $\beta$-D-Galactopyranosyl, glc: $\beta$-D-Glucopyranosyl, ara: $\alpha$-LArabinopyranosyl, xyl: $\beta$-D-Xylopyranosyl, rha: $\alpha$-L-Rhamnopyranosyl) (Singh et al., 2017). 
RFOs have been proposed to act as protective agents during desiccation and storage of seeds in the dry state, as transport sugar in phloem sap and as storage sugars (Peterbauer et al., 2001; Downie et al., 2003). The mechanisms of action through which these sugars could confer to the seed a tolerance of drying and acclimatization against cold are based on the stabilization of cellular components. They participate in several cellular functions such as transport and storage of carbon, signal transduction (Xue et al., 2007), membrane trafficking (Thole and Nielsen, 2008), and mRNA export (Okada and Ye, 2009). They also act as signaling molecule following pathogen attack and wounding (Couée et al., 2006; Kim et al., 2008).

RFOs are $\alpha$-1,6-galactosyl extensions of sucrose. The galactosyl group of RFOs is donated by galactinol (Gol; 1-O- $\alpha$-D-galactopyranosyl-L-myo-inositol). Synthesis of Gol is a key and absolute requirement for entering into the pathway of RFO biosynthesis (Sengupta et al., 2015) (Figure 14).

One of the phenomena produced by legume consumption is the formation of gases at the colon level, due to the absence of the enzyme $\alpha-(1-6)$-galactosidase necessary to hydrolyse the $\alpha$-galactosides. These sugars, because they cannot be digested and do not pass through the intestinal wall, pass intact to the colon, where they are metabolized by bacteria. This metabolic process produces short-chain fatty acids that reduce $\mathrm{pH}$, as well as carbon dioxide, hydrogen and methane. These gases are responsible for flatulence, which manifests itself in the form of nausea, abdominal pain, cramps, constipation or diarrhea.

Although RFOs have long been regarded as antinutritional factors in human nutrition, RFOs have a beneficial role as prebiotics (Voragen, 1998; Aranda et al., 2000), promoting the proliferation of bifidobacteria and lactobacilli that generate health benefits (Rubio et al., 2005). Monogastric animals cannot digest these sugars, leaving them available in the colon to be used by beneficial intestinal bacteria as a source of carbon and energy for maintenance and growth. The large number of bifidobacteria and lactobacilli generated in the colon synthesize antibiotic substances and produce high levels of short-chain fatty acids that reduce the $\mathrm{pH}$ of the medium. Through these mechanisms, these beneficial bacteria reduce the proliferation of pathogenic bacteria (Delzenne and Roberfroid, 1994). 


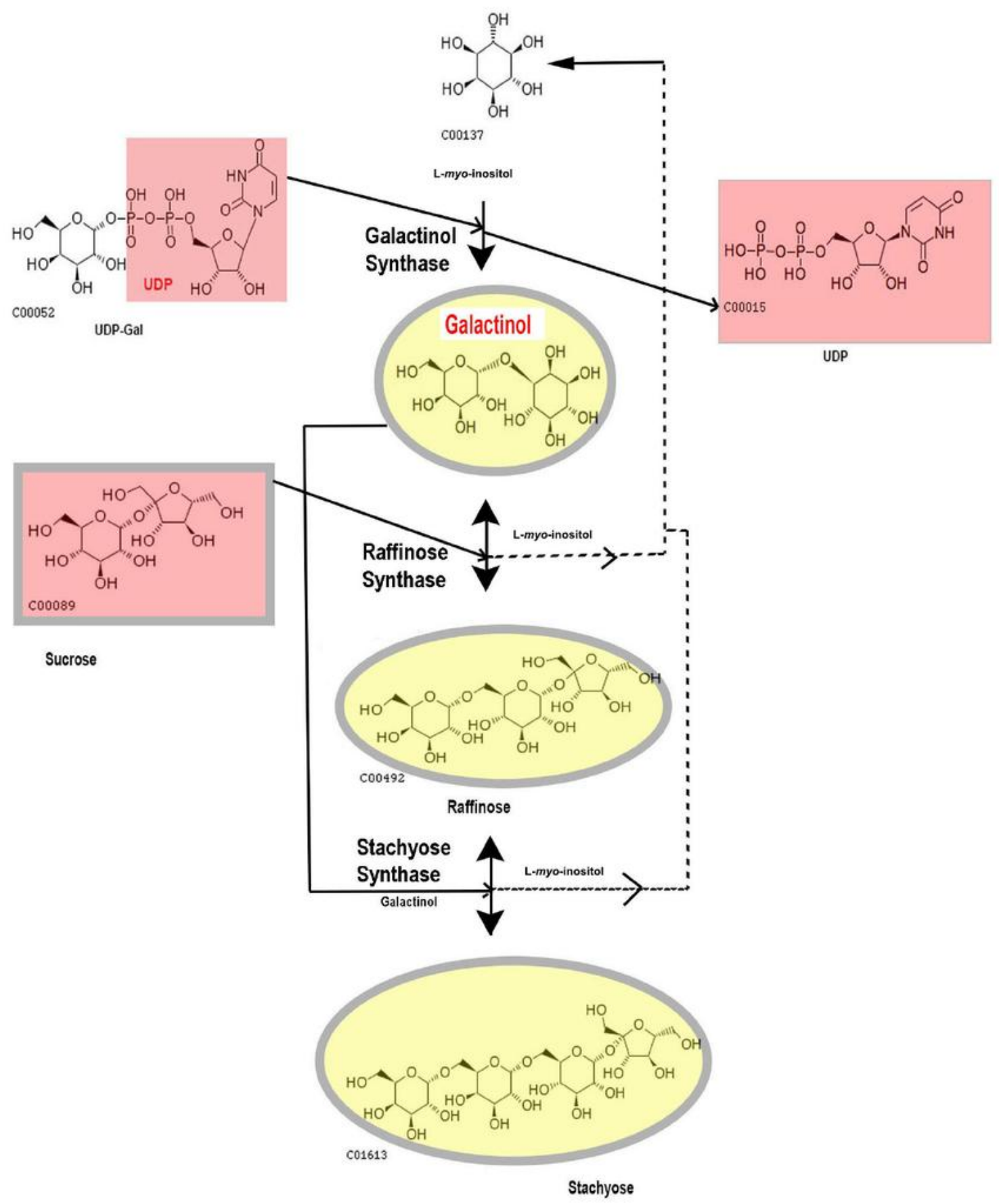

Figure 14. The biochemical pathway of RFO synthesis (Sengupta et al., 2015)

With this drop in $\mathrm{pH}$, the solubility of minerals such as $\mathrm{Ca}, \mathrm{Mg}$ or Fe is also increased, so that oligosaccharides could be used in the prevention of osteoporosis, in $\mathrm{Mg}$ deficiency states or in anemia situations (Grizard and Barthomeuf, 1999). The increase in bacterial mass favors a larger fecal bolus size, reducing the possibility of colon cancer and constipation (Delzenne and Roberfroid, 1994). 


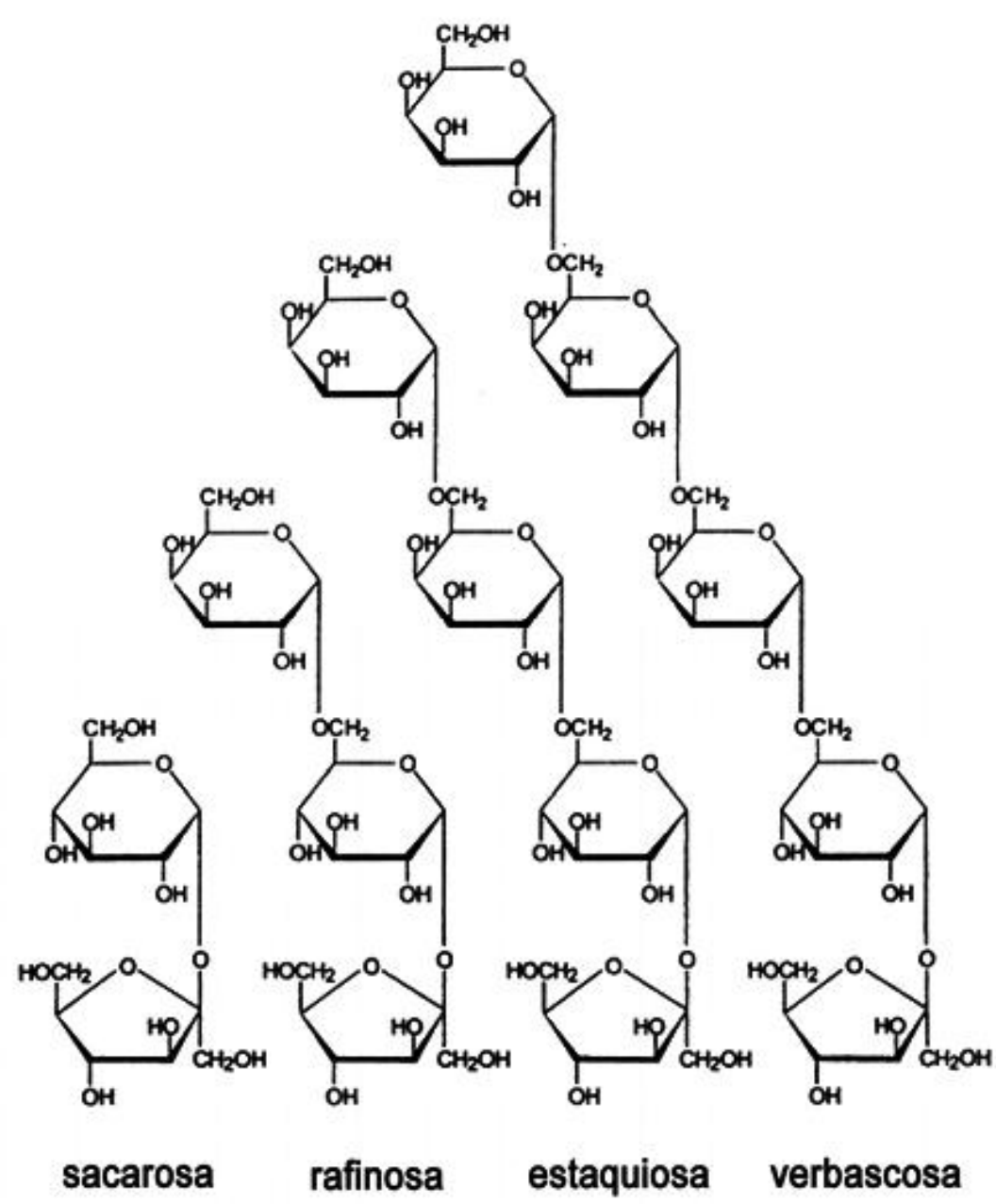

Figure 15. Chemical structure of sucrose and RFO (Goyoaga, 2005)

\subsubsection{Phytic acid}

Phytic acid (IP6) (Figure 16) is a natural antioxidant that is found in vegetables, where it serves as the storage form of phosphorus and represents $60 \%$ to $90 \%$ of the total phosphorus present in the seeds used in food and feed (Wu et al., 2009; Silva and Bracarense, 2016). It is a compound widely distributed in legume seeds, which can be degraded by phytases. These enzymes belong to the phosphatase group, and are able to hydrolyze sequentially IP6 to myo-inositol esters with fewer orthophosphate groups (myinositol pentachis-, tetrakis-, tri-, di- and monophosphate) and inorganic phosphate (Goyoaga, 2005). 


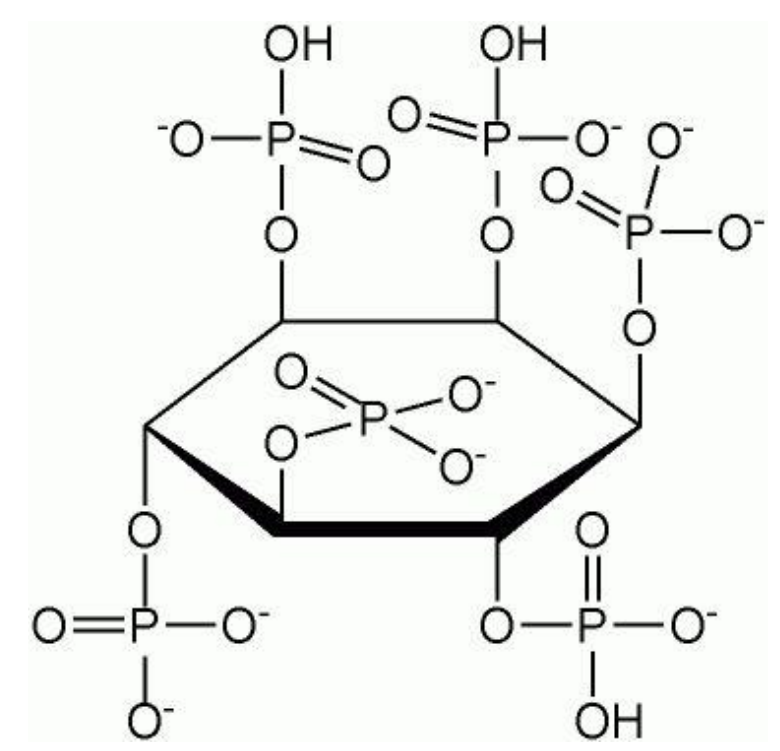

Figure 16. Chemical structure of phytic acid (Wu et al., 2009)

IP6 could be a seed dormancy inducer, since by binding to multivalent cations necessary for the control of cellular processes; metabolism slows down (Gibson and Ullah, 1990). In addition, because of its antioxidant properties, IP6 could preserve seed viability during the dormancy period (Graf et al., 1987). It has traditionally been considered as an antinutrient because of its binding to proteins, minerals and starch, with which it forms complexes that cannot be assimilated (Figure 17).

Phytic acid has a strong ability to form a complex with multivalent metal ions, especially zinc, calcium and iron. This binding can result in very insoluble salts with poor bioavailability of the minerals (Wu et al., 2009). Monogastric animals, including humans, have few phytases in the stomach and small intestine, so that they cannot hydrolyze the phytic acid molecule and use the phosphorus found in its structure, nor the minerals with which it forms salts (Steer and Gibson, 2002), causing severe mineral ions deficiency.

Another nutrient limitation is the ionic interaction of phytic acid with proteins forming protein-phytate complexes at acid $\mathrm{pH}$ and protein-mineral-phytate at basic $\mathrm{pH}$. Because of these phytate-enzyme protein interactions, phytic acid inhibits digestive enzymes 
such as lipases, proteases or $\alpha$-amylases, paralyzing enzyme reactions at the digestive level (O`Dell and Boland, 1976; Knuckles and Betschart, 1987).

The interactions of phytic acid with cations can sometimes be beneficial, as in the case of its binding to toxic metals such as $\mathrm{Cd}^{2+}$ or $\mathrm{Al}^{3+}$ to be excreted by faeces (Evans and Martin, 1988). It also has anti-cancer properties, since thanks to its combination with $\mathrm{Zn}^{2+}$ and $\mathrm{Mg}^{2+}$, it reduces the bioavailability of these minerals necessary for DNA synthesis, preventing cell proliferation (Steer and Gibson, 2002).

Inositol hexaphosphate acts as a plasma hypolipidemic agent, minimizing the risk of cardiovascular disease. This is due to its greater affinity for $\mathrm{Zn}^{2+}$ versus $\mathrm{Cu}^{2+}(\mathrm{Zulet}$ and Martínez, 2001). Phytic acid can slow down digestion and absorption of starch, resulting in delayed glucemic response, so less insulin is required and reduces the risk of diabetes (Pallauf and Rimbach, 1997).

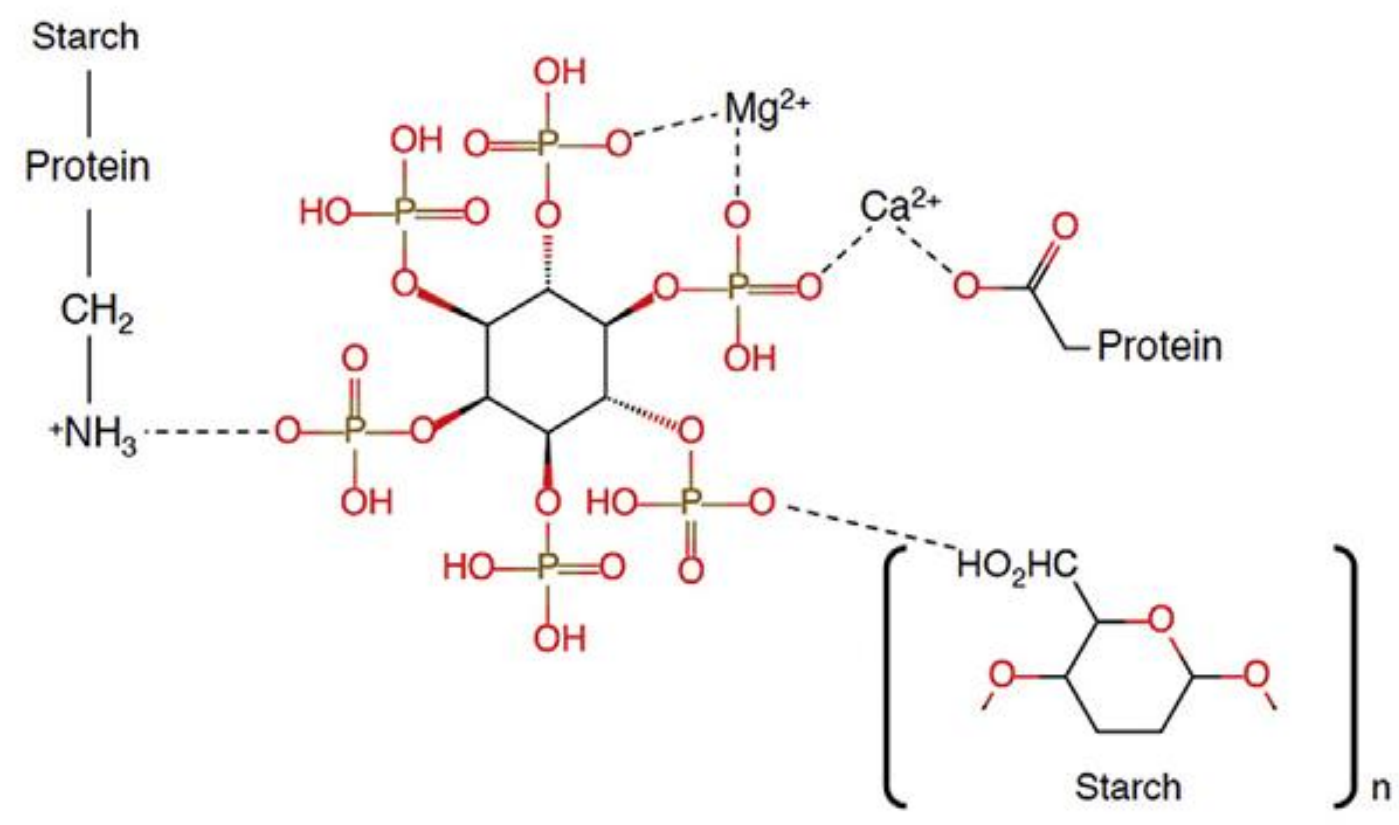

Figure 17. Interaction of phytate with minerals, proteins and starch. 


\section{MINIMAL PROCESSING OF LEGUMES}

\subsection{Overview}

The current life style, with little time to cook balanced meals and the increase of interest about healthy food, has driven the demand towards natural, fresh and ready-to-eat vegetable products, as the fresh cut or minimally fresh processed (MFP) fruit and vegetables. In addition, there are increasing demands for extension of shelf life to better meet longer and more global distribution chains, and minimally processed products can meet that demand. In addition, after storage and commercialization, that product could be consumed fresh or directly microwaved if packaged in a suitable container (Klug et al., 2108a). Given that, a healthy cooked food with high organoleptic quality would be quickly obtained.

Fresh and fresh-cut products continue all metabolic processes, and are susceptible to quality deterioration and microbial infestation mainly due to increase in respiration and transpiration, that play a significant role in the postharvest quality of fresh-cut vegetables. Passive modified atmosphere packaging (MAP) can be generated inside the package depending on respiration and film permeability to attain the desired gas composition over time. MAP offers the possibility to extend the shelf life of fresh product, by reducing respiration rate by decreasing $\mathrm{O}_{2}$ concentration around the fresh produce. Decreasing respiration rate and lowering temperature delays enzymatic degradation of complex substrates and reduces sensibility to ethylene synthesis (Artés et al., 2012).

Plastic films of selective permeability must be selected taking into account the permeability to gases of physiological interest $\left(\mathrm{O}_{2}, \mathrm{CO}_{2}, \mathrm{C}_{2} \mathrm{H}_{4}\right.$ and water vapour). The optimal balance of gases inside the package is created by diffusion of these gases, which are generated by the breath of the product and its interaction with the permeability of the polymer (Artés et al., 2012; Kader et al., 2002). Minimum $\mathrm{O}_{2}$ and maximum $\mathrm{CO}_{2}$ concentration must be attained, but considering that excessively low $\mathrm{O}_{2}$, below $1 \%$, may result in anaerobic respiration leading to tissue deterioration as well as production of off-odors and off-flavors (Caleb et al., 2013). Also, maintaining high levels of RH and reduced water loss are a common outcome of MAP which can prove beneficial for many fruit and vegetables (Wilson et al., 2017). 
For fresh-cut products, sanitation is one of the most critical steps in their production process, due to the effects it has on microbial load and, consequently, on quality, safety and shelf-life (Otón et al., 2015). In general, the industry has widely used sodium hypochlorite $(\mathrm{NaOCl})$ due to its antimicrobial activity and low cost. However, it is controversial because it can be potentially harmful due to the formation of toxic byproducts like trihalomethanes and chloramines (Otón et al., 2014; Artés et al., 2009), and because several studies have reported that $\mathrm{NaOCl}$ could be insufficient to reduce normal microflora in fresh-cut products (Foley et al., 2004). Therefore, others disinfectants, both chemical (acidified sodium chlorite, ascorbic acid, citric acid, etc.) and physical (UV light), as well as edible coatings, are increasingly being studied as alternative to $\mathrm{NaOCl}$ disinfection (Otón et al., 2016; Artés-Hernández et al., 2014 and 2017).

Fresh-cut industries are continuously looking for and applying new technologies to extend the commercial life of their products keeping the best sensory, nutritional and microbial quality. All these aspects, in addition to their high nutritional value, confer great advantages for consumers and food services (Artés y Artés-Hernández, 2012; Artés-Hernández et al., 2017):

- Reduces preparation time, as they are ready for consumption

- They have characteristics very similar to the original product

- Present uniform and consistent high quality

- Encourage the supply of healthy products

- Reasonably priced

- Easy to store

- Produce little or no waste

\subsection{Current state of the fresh-cut market}

These companies were born in the early 1970s in the U.S. to meet the demand for fresh salads in fast food shops. During the 1980s, they spread to European countries such as Germany or Switzerland, and years later followed their development in the United Kingdom, France, the Netherlands and Italy. In Spain, MFP products did not appear on the market until the early 1990s (Artés and Artés-Hernández, 2003). 
The European fresh-cut industry has shown exponential growth since its appearance in the early 1980s. UK is the major fresh-cut produce consumer because the ready-to-eat product culture is deeply established in that country. In countries like Germany and Spain, in which fresh-cut fruit and vegetables market is still emerging, the market growth in the last years was higher than other countries in which this market is already established, for instance Italy and the Netherlands. In the 2015-2016 campaign, the fresh-cut market in Spain increased 15\%. Concerning the features of the fresh-cut market, packaged salads appear to be the leader of fresh-cut products, in fact they hold about $50 \%$ of total fresh-cut market volume. The other $50 \%$ is shared by the fresh-cut fruit $(10 \%)$ and the other categories as ready-to-cook, crudités and other with $40 \%$ (MAGRAMA, 2019).

\subsection{Units operations during minimally fresh product processing}

The units operations during fresh-cut products production depend on the fruit or vegetable used for each case. However, the general steps as unit operations in the freshcut products elaboration are presented in Figure 18 and subsequently described. 


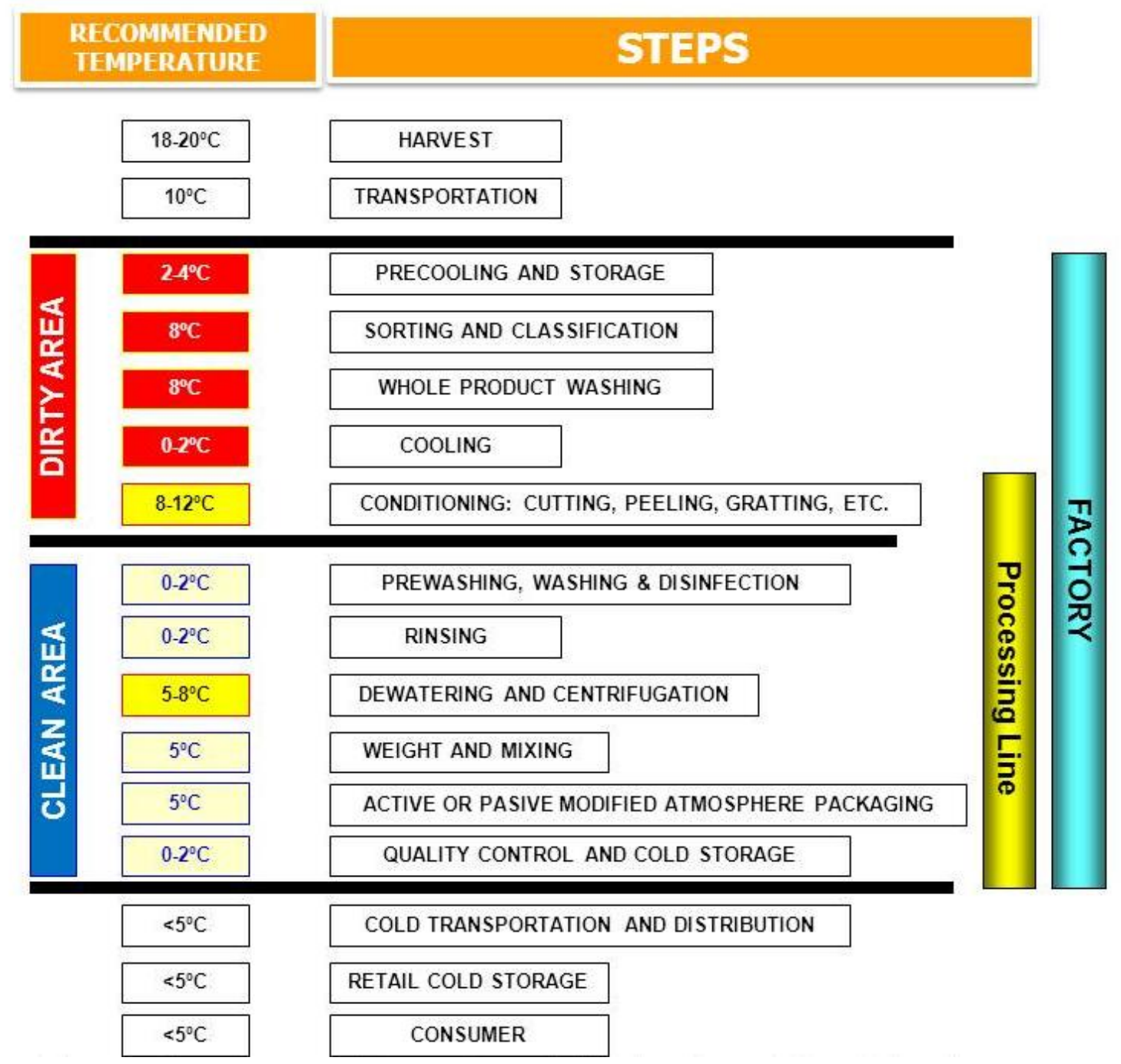

Figure 18. Flow chart of the general minimal processing steps and recommended temperatures (Artés-Hernández et al., 2013)

\subsubsection{Raw material}

The physiological behavior and the suitability for the fresh cut vegetable processing that ensure a good postharvest quality and shelf-life may be influenced by the following preharvest factors (Yildiz et al., 1994):

- Genetic factors: varieties, etc.

- Climate conditions: light, temperature, relative humidity, rainfall, etc.

- Soil conditions: soil type, $\mathrm{pH}$, humidity, microbiota, mineral composition, etc.

-Agricultural practices: fertilization, pesticides, irrigation type, pollinisation, etc. 
When referred to legumes, pods must be picked up at the appropriate ripening stage (Figure 19), as if they are harvested too early, the economic yield will not be as high as can be expected and, if harvesting is delayed, the pods will harden and the product will be much less valuable (MAPAMA, 2019). The harvest season depends on the variety and climatic conditions. Green grain harvesting can be done manually or mechanically with combine harvesters, when the grains have an average moisture content between 70$75 \%$ (in case of peas) or when the pod reaches $3 / 4$ of the final size and before the hilum turns black (in case of beans). These values are for open field crops.

Pods should be uniformly green (light to deep green but not yellow-green), fully turgid, clean, and free from damage (thrips injury, broken pods). The stem and calyxes should be green and there should be very few blossoms attached to the pods (Suslow and Cantwell, 1998).

The green pods, if they are intended for fresh consumption, must be quickly classified, packaged and marketed in order to avoid losses in quality and losses in production.
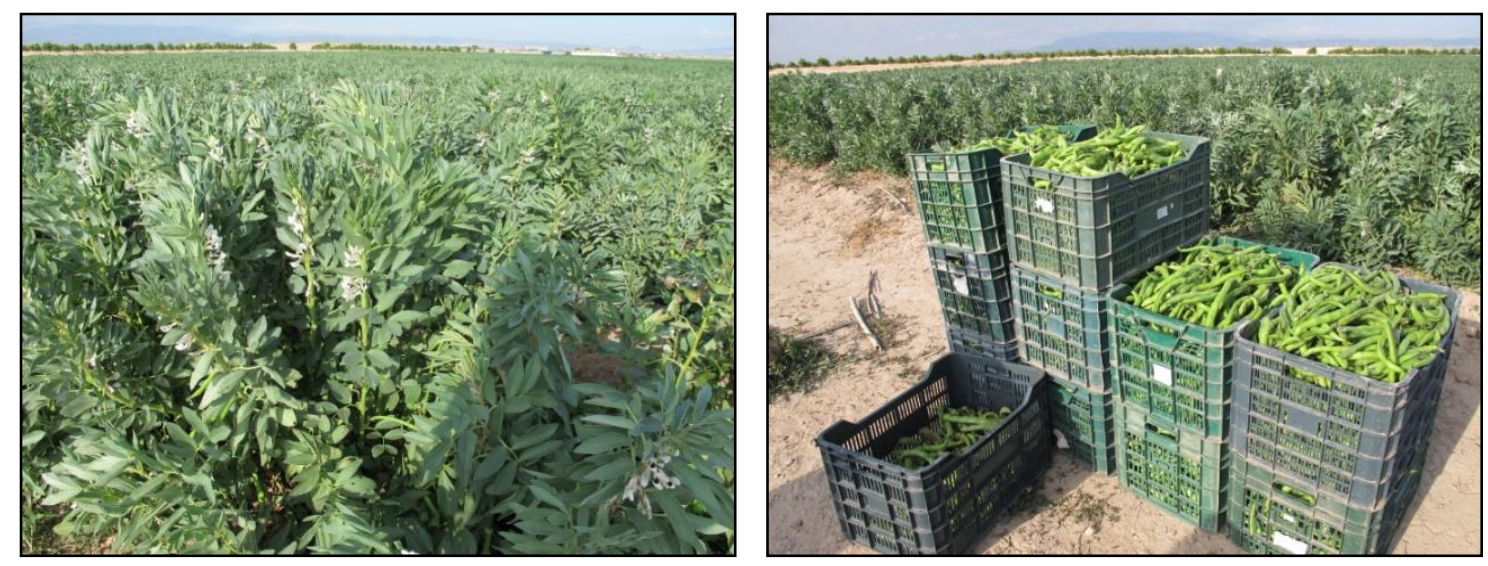

Figure 19.Growing filed of faba beans (left) and collected beans (right)

\subsubsection{Transportation and reception}

It should take less than an hour between harvesting and arrival at the processing plant. A refrigerated transport $\left(5^{\circ} \mathrm{C}\right)$ is recommended if distance is far. When the raw material arrives at the processing plant it is selected according to quality standards. If it is inadequate or deficient, it must be rejected and it will not be possible to process this 
way. In this step, the product is also weighed once it has been classified, both for control during processing, product formulation and quality control.

\subsubsection{Precooling and storage}

Pre-cooling should be performed to rapidly decrease product temperature. This is one of the most important steps to extend the shelf-life of these high-metabolic-rate vegetables, slows down the stress generated during the processing stages and maintains better product quality. Pre-cooling also has the advantages of reducing (ArtésHernández et al., 2013):

- weight loss and withering

- microbial growth

- deterioration

- the emission of and sensitivity to ethylene

Raw material is usually pre-cooled with forced air and stored between 0 to $4^{\circ} \mathrm{C}$ and $95 \%$ $\mathrm{RH}$ for a few hours or a day to regulate the supply to the processing line before processing (Artés-Hernández et al., 2013).

\subsubsection{Sorting, classification and peeling}

Good sorting and classification will facilitate subsequent processes, increasing line productivity and the quality of the final product. The selected seeds must be of a similar size, be of an intense green color, uniformly developed, and free of damages and pathogens (Acuña, 2011). The selection is manually made by choosing or separating grains of another colour, broken, deformed or immature, and other materials such as pods or leaves, to obtain a clean and quality product.

Legume seeds have one of the highest respiration rates (RR) among fruit and vegetables (27-38 $\mathrm{mL} \mathrm{CO}_{2} \mathrm{~kg}^{-1} \mathrm{~h}^{-1}$ at $5^{\circ} \mathrm{C}$ in peas) (Suslow and Cantwell, 1998). The peeling of pods increases the RR, ethylene emission and tissue damage of the product and therefore accelerates the velocity of senescence of the tissue and reduces resistance to microbial contamination (Artés et al., 2009). 
In order to minimize these undesirable effects of shelling, the operation must be done in a cold room $\left(5 \pm 1^{\circ} \mathrm{C}\right)$ and the obtained seeds must be immediately immersed in cold water at $4 \pm 1^{\circ} \mathrm{C}$. Pods can be manually or mechanically shelled in a chamber previously disinfected (Figure 20). The cutting equipment must be cleaned, disinfected and sharpened at regular intervals every working day.

The conditioned product must be directly conducted from the dirty to the clean area for further processing.
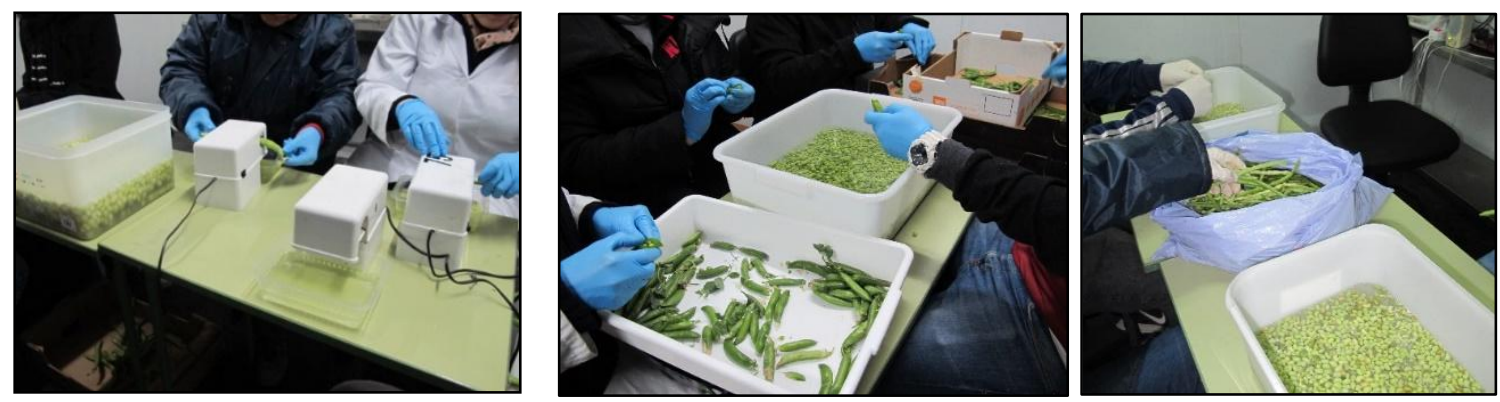

Figure 20. Peeling of faba beans (left), peas (center) and cowpea (right) in a cold room

\subsubsection{Washing, disinfection and rinsing}

Washing and disinfection reduces the microbial load of the product (Suslow, 1997; Artés et al., 2009; Otón et al., 2015), since fresh products that have not undergone any heat treatment may transmit infectious diseases (Leistner and Gould, 2002; Harris et al., 2003; Allende and Artés, 2005). Also, microbial load affects postharvest life, since it might cause produce deterioration and senescense. Chlorine (in various forms) has been widely used as a disinfectant in the fresh cut industry. $\mathrm{NaClO}$ is the most commonly used disinfectant in the fresh cut industry due to its strong oxidizing properties, antimicrobial activity and low cost. In this way, the washing and disinfection of legumes are made with cold chlorinated water $\left(4^{\circ} \mathrm{C} ; 150 \mathrm{mg} \mathrm{L}{ }^{-1}\right.$ free $\left.\mathrm{Cl}_{2}\right)$, which is acidified ( $\mathrm{pH}$ 6.5-7.5) with citric acid to increase the bacteriostatic effect of chlorine. The ideal contact time is around $2 \mathrm{~min}$.

A rinsing step of the product with cold tap water $\left(1-2{ }^{\circ} \mathrm{C}\right)$. The washing and rinsing efficacy can be improved by the generation of turbulences by pressure-air injection in 
the water baths, although pressure showers, drive chains or rotating drums can be alternatively used (Artés-Hernández et al., 2017).

Sodium hypochlorite is controversial because it can be potentially harmful due to the formation of toxic by-products like trihalomethanes and chloramines (López-Gálvez et al., 2010, Otón et al., 2014), that have known or suspected carcinogenic or mutagenic potential effect with proved toxicity to liver and kidney (Nieuwenhuijsen et al., 2000; Hrudey, 2009; Ölmez and Kretzschmar, 2009). Also several studies have reported that $\mathrm{NaOCl}$ could be insufficient to reduce normal microflora in fresh-cut products (Foley et al., 2004). These negative aspects related to chlorine have induced some European countries (Germany, The Netherlands, Denmark, Switzerland and Belgium) to forbid the use of $\mathrm{NaClO}$ for disinfection of fresh cut produces (Artés et al., 2011).

Consequently, the food industry is now looking for alternatives to chlorine which may assure the safety of the fresh cut products and maintain the quality and shelf-life, while also reducing the rate of water consumption during processing. Thus, sustainable sanitising alternatives to $\mathrm{NaClO}$ have been proposed. Among these techniques $\mathrm{UV}-\mathrm{C}$ light, edible coatings and alternative acids can be considered.

\subsubsection{1. $U V$-C radiation}

The use of non-ionizing, germicidal, artificial and most energetic fraction of the UV spectra UV light (wavelength of 190-280 nm, corresponding to the UV-C range) could be effective for surface decontamination of fresh cut products using germicidal lamps (254 nm) (Selma et al., 2008, Artés et al., 2009).

UV-C affects several physiological processes in plant tissues and damages microbial DNA. UV-C acts indirectly by stimulating plant defense mechanisms, but also UV light promotes photo-oxidative reactions in plants producing reactive oxygen species (ROS). The major ROS are singlet oxygen, hydrogen peroxide and hydroxyl radicals. The free radicals generated from UV radiation can target cell membranes, nucleic acids, cell walls and enzymes, inducing the acceleration of senescence (Turtoi, 2013). For this reason, it is very important to find a safe dose which greatly weakens microbial development without damaging the product (Artés-Hernández et al., 2010). 
The antimicrobial effect of UV-C light is due to its ability to damage microbial DNA and to a lesser extend denatures proteins. The damage caused by UV-C probably involves specific target molecules and a dose in the range from 0.5 to $20 \mathrm{KJ} \mathrm{m}^{-2}$ leads to lethality by directly altering microbial DNA (Bintsis et al., 2000). Furthermore, it induces the formation of pyrimidine dimers, which distort the DNA helix and block cell replication, compromising cellular functions and eventually leading to cell death. (Manzocco et al., 2011).

The effectiveness of $\mathrm{UV}-\mathrm{C}$ seems to be independent of the temperature in the range of $5-37^{\circ} \mathrm{C}$ but depends on the incident irradiation, as determined by the structure and surface of treated product (Bintsis et al., 2000; Gardner and Shama, 2000; Lado and Yousef, 2002). Furthermore, the germicidal action of UV light is strongly dependent on the natural resistance of the microorganisms. Also, it was established that bacterial spores and stationary phase cells are more resistant to $\mathrm{UV}-\mathrm{C}$ than vegetative and exponential phase cells (Warriner et al., 2009). The germicidal effect occurs over relatively short time that is essentially limited to the time of exposure of the microorganism to the UV source (Turtoi et al., 2013).

The use of UV-C light has been proposed for surface disinfection of fresh cut fruit and vegetables. Some studies have reported that UV-C inhibited microbial growth, delaying decay and senescence. In zucchini squash slices UV-C exposure reduced microbial activity and deterioration during subsequent storage at 5 or $10{ }^{\circ} \mathrm{C}$ (Erkan et al., 2001). Robles et al. (2007) indicated that UV-C-treated tomatoes showed retarded ripening and kept better firmness and sensory attributes than those air-stored. This process could be related to an increased enzymatic activity caused by membrane disruption with the consequent loss of compartmentalization (Gómez et al., 2010). Similarly, exposure to UV-C doses (4.5-9 $\mathrm{kJ} \mathrm{m}^{-2}$ ) of kalian-hybrid broccoli reduced mesophilic loads by approximately $1.2 \mathrm{log}$ units while enterobacteria and psychrophilic were unaffected (Martínez-Hernández et al., 2011, 2013d).

It has been reported that abiotic stresses such as that from UV-C light may enhance the nutraceutical content of fresh fruit and vegetables. It would affect secondary metabolism of fresh produce and would increase synthesis of phytochemicals with nutraceutical activity or reduce synthesis of undesirable compounds (Cisneros-Zevallos, 2003). 
Treatment with ultraviolet energy offers several advantages to food processors as it does not leave any residue, is easy to use and lethal to most types of microorganisms (Bintsis et al., 2000), the equipment is relatively inexpensive (Yaun et al., 2004) and does not have legal restrictions since Food and Drug Administration approved UV-C light as a disinfectant technology for surface treatment of food (USDA-FDA, 2002).

The best equipment for application of the UV-C technique in the fresh cut industry are the UV-C tunnels, where the product would circulate on a conveyor belt. There are other discontinuous systems (UV-C drums, UV-C hoods, etc.) used at pilot plant scale or for the small production industries. The Figure 21 shows a faba beans sanitation in a UV-C hood.

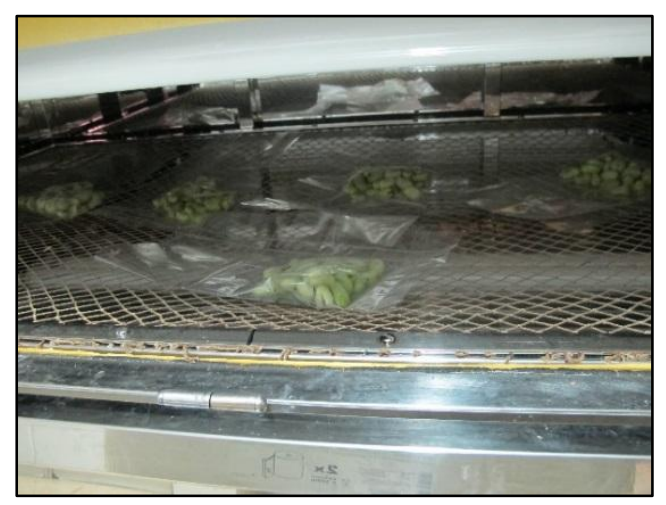

Figure 21. Faba beans sanitation with $U V-C$ light at a pilot plant scale (discontinuous system).

\subsubsection{Edible coatings}

Edible antimicrobial films or coatings (EC) can avoid browning and improve the quality, safety, shelf life and functionality of foods products by reducing moisture transfer, respiration rate and oxidative processes, while minimizing both spoilage and pathogenic microorganisms (Raybaudi-Massilia et al., 2016).

Edible coatings are defined as a thin layer of material that covers the surface and can be ingested as part of the entire product. Its composition must comply with all regulations that apply to the product used (Guilbert et al., 1995). In accordance with the European Guidelines (ED, 1995; 1998) and FDA (2006), edible coatings must be made from 
ingredients suitable for food consumption. Ingredients that can be incorporated into their formulations include: karaya and Arabic resin, pectins, shellac, beeswax and carnauba wax, lecithin, polysorbates, fatty acids and fatty acid salts (ED, 1995 and 1998).

The functional characteristics required for a coating depends on the product matrix and the deterioration processes that the product is subjected to. However, edible coatings must meet a number of functional requirements (Kester and Fennema, 1986):

- Sensory properties: transparent, tasteless and odourless.

- Barrier properties: suitable permeability to water vapour and solutes and selective permeability to gases and volatile compounds.

In addition, formulations should be microbiologically safe, suitable for human consumption and the cost of technology and materials used during processing should be relatively low.

The use of EC in food applications and especially highly perishable products such as horticultural ones, is conditioned by the achievement of diverse characteristics such as cost, availability, functional attributes, mechanical properties (flexibility, tension), optical properties (brightness and opacity), the barrier effect against gases flow, structural resistance to water and microorganisms and sensory acceptability (Falguera et al., 2011).

Edible coatings can create a modified atmosphere by modifying internal gas composition retarding ripening and reducing decay. However, a certain degree of oxygen and carbon dioxide permeability is necessary to avoid anaerobic respiration, which would result in physiological disorders and a rapid loss of quality. (MoldaoMartins et al., 2003). Application of EC on faba bean seeds at pilot plant scale is showed in Figure 22.

Edible coatings and films are usually classified according to their structural material. In this way, films and coatings are based on proteins, lipids, polysaccharides or composite. For example, a composite film may consist of an oil-in-water emulsion. 
Edible coatings can affect the quality of the product very differently, as different biological mechanisms are involved. These include control of moisture loss in the product, loss of chemical compounds such as antimicrobials, sugar compounds or antioxidants, reduction of partial pressure of $\mathrm{O}_{2}$ within the product with a consequent decrease in its metabolism, as well as some restructuring of its internal structure (Shaidi et al., 1999). Some of the effects observed in products to which edible films have been applied include a reduction in RR (Gaouth et al., 1991; Wong et al., 1994), weight loss (Baldwin et al., 1999), enzymatic browning (Baldwin et al., 1999; McHugh and Senesi, 2000; Le Tien et al., 2001) and overall, a significant increase in product shelf life.
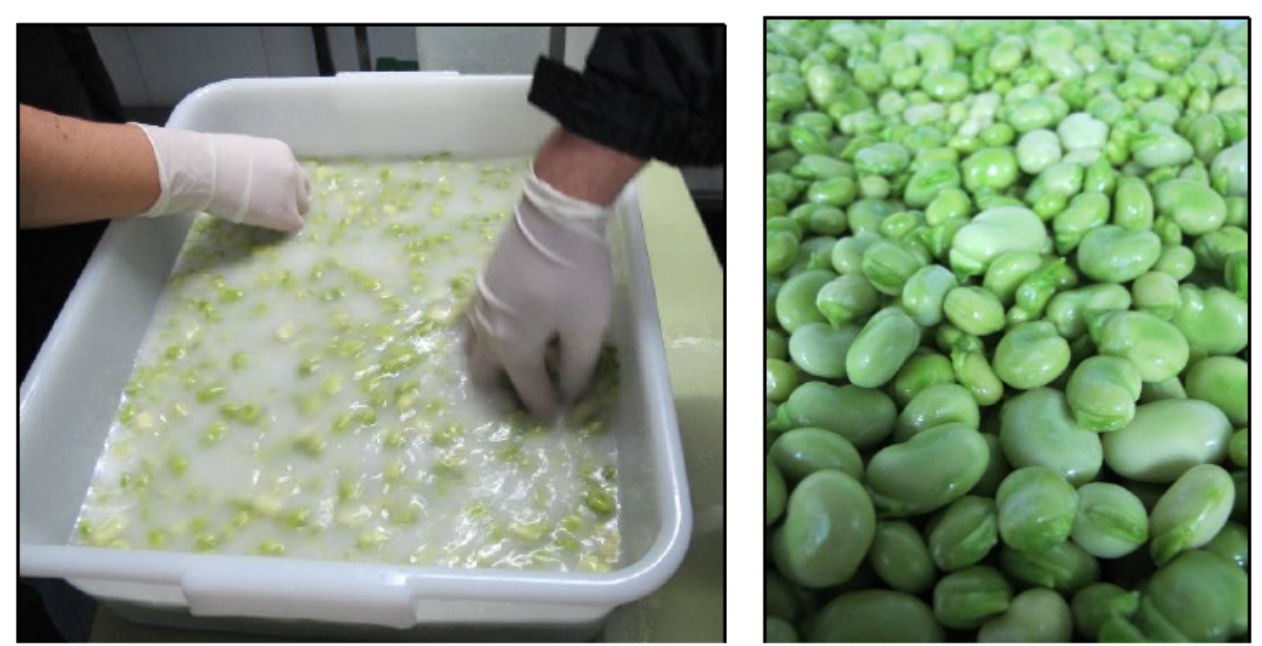

Figure 22. Faba beans sanitation with an edible coating (Naturcover-P, Decco Iberica, Spain) (left) at a pilot plant scale, and seeds drying after the treatment (right)

\subsubsection{Organic acids and acidified solutions}

Sanitizing agents are usually added to process water to reduce microbial populations and prevent cross-contamination of products. As alternatives to chlorine, some organic acids such as citric acid (CA) and ascorbic acid (AA), and other chemicals, as acidified sodium chlorite (ASC), have been proposed. These compounds have been applied largely for the prevention of enzymatic and non-enzymatic browning (Sapers, 1993), texture deterioration (Rosen and Kader, 1989) and microbial growth (Yildiz, 1994) at concentrations that did not adversely affect taste and flavour of plant commodities. Application of organic acids on faba bean seeds at pilot plant scale is showed in Figure 23. 
The ASC is approved by FDA as a secondary additive in the food industry. The antimicrobial activity of ASC is attributed to the oxidative effect of chlorous acid $\left(\mathrm{HClO}_{2}\right)$, which is derived from the conversion of chlorite ion into its acid form under strong acidic conditions (Tomás-Callejas et al., 2012). When ASC comes into contact with organic matter, a number of oxychlorous antimicrobial intermediates are formed. These substances are broad-spectrum germicides that act by breaking oxidative bonds on cell membrane surfaces. The fundamental nonspecific oxidative mode of action of this chemistry is thought to also minimize the potential problem of acquired resistance that often arises in bacterial populations following prolonged exposure to antimicrobial procedures (Yousuf et al., 2018).

Inatsu et al. (2005) evaluated the efficacy of ASC in reducing the load of pathogenic microorganisms in lightly fermented chinese cabbage: washing the inoculated leaves with distilled water reduced the load of E. coli O157: $\mathrm{H} 7$ in less than $1 \mathrm{UFC} \mathrm{g}^{-1} \log$ while a dilution of $0.5 \mathrm{~g} \mathrm{~L}^{-1}$ ASC reduced the population by more than $2 \log \mathrm{UFC} \mathrm{g}^{-1}$. Allende et al. (2009) found a reduction of $3 \log \mathrm{UFC}^{-1}$ in the population of E. coli O157: $\mathrm{H} 7$ in washed MFP cilantro with $1 \mathrm{~g}$ ASC L ${ }^{-1}$ compared to control. Also, TomásCallejas et al. (2012) observed that after using ASC (300mg L $\mathrm{L}^{-1}$ ) on fresh-cut tatsoi baby leaves the total aerobic mesophilic bacteria remained stable throughout storage for 11 days at $5^{\circ} \mathrm{C}$.

Organic acids such as CA or AA, which are in GRAS status, have been described as strong antimicrobial agents against psychrophilic and mesophilic microorganisms in fresh-cut fruit and vegetables (Uyttendaele et al., 2004; Bari et al., 2005). The antimicrobial action of organic acids is due to environment $\mathrm{pH}$ reduction, disturbance of membrane transport and/or permeability, anion accumulation, or a reduction in internal cellular pH (Neal et al., 2012). Less direct antibacterial activities include interference with nutrient transport, cytoplasm membrane damage resulting in leakage, disruption of outer membrane permeability, and influence on macromolecular synthesis (Beuchat, 1998; Inatsu et al., 2005; Miller et al., 2009).

Fresh cut 'Amarillo' melon dipped in $0.52 \mathrm{mM} \mathrm{CA}$ for $30 \mathrm{~s}$ before MAP reached a shelf-life of $10 \mathrm{~d}$ at $5^{\circ} \mathrm{C}$. This treatment maintained microbial safety and avoided 
translucency and discoloration. Compared to the control (1.4 mM NaClO), CA increased lightness and improved visual appearance of melon pieces (Aguayo et al., 2003). Dipping green celery crescents in a $0.5 \mathrm{M}$ ascorbic and $0.1 \mathrm{M}$ citric acid solution was as effective as $100 \mathrm{mg} \mathrm{L}^{-1} \mathrm{NaClO}$ for reducing microbial counts and improving consumer acceptability (Gómez and Artés, 2004).
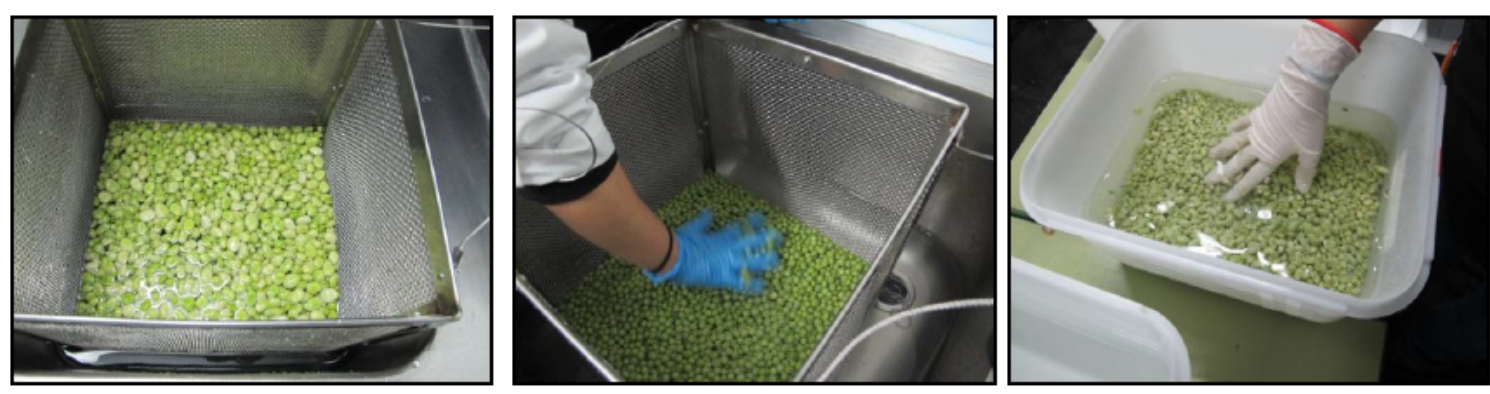

Figure 23. Faba beans (left), peas (centre) and cowpea (right) sanitation with alternative acids

\subsubsection{Dewatering}

The water from the product surface must be removed after rinsing to reduce product moisture and not promote microbial growth and enzyme activity (Simons and Sanguansri, 1997; Soliva-Fortuny and Martín-Belloso, 2003). The drying systems include vibrating belts, hydrofoils, centrifuges, tunnel dryers with forced air. ArtésHernández et al. (2013) recommend using cold air injections on a perforated conveyor belt, although its efficiency may be low for large productions.

\subsubsection{Weight and packaging}

After drying and the possible application of some coating to the product, the desired quantity is weighed and packaged in trays or bags. The most common packaging method for fresh cut is modified atmosphere (MAP). Aspect of faba, peas and cowpea seeds under MAP are showed in Figure 24.
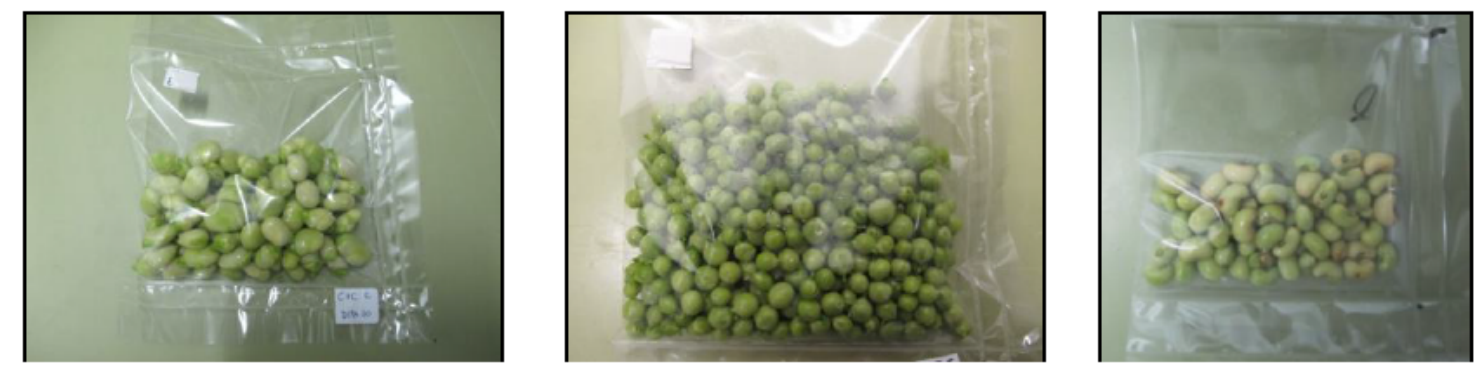

Figure 24. Details of Faba beans (left), peas (centre) and cowpea (right) under MAP. 
It is important avoiding $\mathrm{O}_{2}$ concentrations exceeding the permissible lower limits, as anaerobic disease can occur inside the package and cause tissue damage and foreign flavours and flavours (Watada et al., 1996).

The main benefits of MAP are (Artés-Hernández et al., 2017):

- Reduction of RR.

- Reduction of heat emission from respiration.

- Lowering ethylene activity and subsequent senescence.

- Lowering sugar, vitamin and organic acid losses.

- Total or partial limitation of physiological changes, such as chilling injuries, scalding, browning, etc.

- Lowering microbial growth.

Finally, the containers must be properly labelled including the processing date, expiration date, net weight, producer details and the lot code, which will ensure a good traceability of the final product.

\subsubsection{Quality control and cold storage}

Before the shipment of the product, it must pass a thorough control to ensure the safety and compliance of all quality specifications. In addition, a procedure of product recall when the specifications are not meet must be accomplished. These control measures are normally carried out with machines that have to be adjusted, checked and continuously calibrated.

The bags or trays with the final product shall be placed in boxes which must be quickly stored between 1 and $4^{\circ} \mathrm{C}$ until their distribution, normally within a period of less than one day.

\subsubsection{Cold transportation and distribution}

The recommendable temperature range throughout distribution chain is 0 to $5^{\circ} \mathrm{C}$. However, it is practically impossible to guarantee that this range will be always maintained during transit, distribution and retail display. Temperature is the most 
important factor that influences the shelf-life of fresh cut products. For retail sale, the fresh cut products must be placed in special display cabinets at $0-5^{\circ} \mathrm{C}$ (although $0-1^{\circ} \mathrm{C}$ is preferable) in the food supply chains. However, it has already been demonstrated that fresh cut products are often subjected to temperature abuse of about $12^{\circ} \mathrm{C}$ in the display cabinets of supermarkets. The inadequate temperature management during distribution and marketing, together with excessive temperature fluctuations during storage, can result in changes of the gas partial pressures within the MA packages. These MA alterations induce a consequent RR increment, heat production and water condensation within the package. In this way, the latter effects will reduce the shelf-life of the fresh cut product with high microbial spoilage risk. Sometimes, time-temperature integrators are used on packages to prevent abusive temperatures during transport and distribution. However, financial and environmental costs have limited the implantation of this technique (Artés and Artés-Hernández, 2003).

\subsection{Overall quality and safety of fresh cut vegetables}

The expected characteristics of fresh cut products by consumers are freshness, optimum overall quality (general appearance, sensory quality -texture/firmness, aroma and tasteand nutritional quality) and safety. However, during fresh cut processing and retail period some physiological, physical and nutritional changes may occur, reducing the expected quality attributes. Furthermore, some pathological disorders can appear in the fresh cut products, which can highly limit the shelf-life and safety of the fresh cut product (Artés-Hernández et al., 2013).

\subsubsection{Physiological, physical and pathological disorders}

The fresh-cut processing steps may increase the metabolism of the plant material, reflected in higher respiration rates $(\mathrm{RR})$ and $\mathrm{C}_{2} \mathrm{H}_{4}$ emission, which usually leads to a faster deterioration rate (Artés et al., 2007). Temperature is the most important factor that affects the metabolism of these products, and the optimal conservation will depend on the type of product, the cultivar and exposure time. They are also very sensitive to weight loss, because when peeling, seeds are exposed to the absence of protection of the pod. 
However, RH is generally very high within the package and dehydration is not a big problem. MAP can be beneficial for keeping $\mathrm{RH}$ and maintaining the product quality (Artés et al., 2009).

The action of the enzyme lipoxygenase, which catalyzes peroxidation reactions, should also be taken into account as it can lead to the formation of aldehydes and ketones that are responsible for off-odours during the product's lifetime. These changes in the metabolism of fresh cut legume seeds may be reflected in the following physiological disorders (Suslow and Cantwell, 1998).

- Freezing injury. Appears as water-soaked areas, which subsequently deteriorate and decay. Freezing injury occurs at temperatures of $-0.7^{\circ} \mathrm{C}$ or below (Figure 25).

Physical disorders like rough handling at harvest or damage from shipping containers that can result in translucent areas that are susceptible to decay, should be also minimized (Suslow and Cantwell, 1998).

Common postharvest decay organisms on green seeds are the fungi Pythium, Rhizopus, and Sclerotinia, all of which may occur as 'nests' of decay or on broken or damaged seeds.

\subsubsection{Nutritional and bioactive compounds changes}

The fresh cut processing keys that highly influence the nutritional and bioactive contents are cutting, washing, dewatering, packaging, and processing and storage temperatures (Francis et al., 2012). The most important tool to extend the shelf-life and maintain the quality of the fresh cut fruit and vegetables is the temperature management.

Storage conditions strongly influence the stability of postharvest seed colour in many types of beans. In other legumes there is some evidence that temperature, relative humidity (RH), seed moisture content (SMC) and light are the main factors that affect the stability of seed colour during storage (Hughes and Sandsted, 1975; Nordstorm and Sistrunk, 1977; Nozzolillo and De Bezada, 1984; Park and Maga, 1999). 


\subsubsection{Use of microwaves for cooking}

After storage and marketing, the product could be consumed fresh or directly microwaved if packaged in a suitable container, providing a product of high sensory quality and intact nutritional properties. However, cooking methods may affect the nutrient content and health-promoting compounds of fresh cut products, such as vitamin C, polyphenols and glucosinolates (Martínez-Hernández et al., 2013). Nonetheless, Microwaving is more efficient than conventional cooking methods (boiling, high pressure boiling, steaming, etc.) since it takes shorter cooking times with consequent lower nutritional and sensory losses (Castillejo et al., 2018; MartínezHernández et al., 2013a, 2013b), so cooking in a microwave oven could be an interesting alternative to conventional cooking due to high efficiency and faster processing time (Alajaji and El-Adawy 2006). It has been reported that microwaved faba beans ( $6 \mathrm{~min})$ achieved the same anti-nutritional reductions as conventional boiling (30 min) (Luo and Xie, 2013). Also, LasoYadav et al. (2018) studied the impact of microwave (MW) cooking ( $800 \mathrm{~W}, 15 \mathrm{~min}$ ) and boiling (90 min) on the total phenolic compounds of cowpea dry seeds and observed a higher preservation in MW-treated samples regarding boiling samples.

\subsubsection{Safety aspects of fresh cut vegetables}

The regulation of substances that are used to reduce the microbial load of fresh fruits and vegetables is complex and in some areas uncertain. In each country, the regulatory status of sanitizing solutions is different. The definition of the product used to disinfect wash water depends on 1) the type of product to be washed, and in some cases, 2) to the location where the disinfectant is used (IFPA, 2001). In the USA, the wash water disinfectants used for fresh-cut produce are regulated by the FDA as a secondary direct food additive, unless they are considered to be Generally Recognized As Safe (GRAS) (Gil et al., 2009).

The European Council Directive 94/34/EC (amending Directive 89/107/EEC), on food additives comprises the lists of substances which may legally be added to food if they perform a useful purpose, are safe and do not mislead the consumer. The detailed controls made under the Framework Directive are implemented into the national law of each EU member state and stipulate which food additives are permitted for use, the 
specific purity criteria and conditions of use, including maximum levels for specific additives (Gil et al., 2009).

Spain has adopted the EU legislation (94/34/EC) with the RD 3177/1983 approving the Technical-Sanitary Regulation on Food Additives, RD 111/1991 amending the RD 3177/1983, and RD 1359/1998 approving the procedure for incorporating into the Spanish positive lists of additives authorized in other Member States of the EU which are not included in the Spanish lists, or in doses different from those permitted in these lists.

When the mentioned programs are not properly applied, outbreaks may occur with disastrous consequences (Table 6). According to this, these outbreaks associated with fresh cut products have pointed microbiological safety as the major issue of concern in the fresh cut industry. The microbiological risks which may occur in the fresh cut products can be classified into two categories (Hurst et al., 2002):

- The contamination of the plant material happens during cultivation or harvest by indigenous pathogens.

- The microbiological risk is present during the fresh cut processing, mainly in the cutting and washing steps, since the natural barriers of plant material (waxy outer skins) against microbiological invasion are damaged. Furthermore, cutting operation releases nutrients which can accelerate microbiological growth. 
Table 6. Outbreaks linked to fresh and fresh cut produce from 2005 to 2011 (Olaimat and Holley, 2012).

\begin{tabular}{|c|c|c|c|c|}
\hline Location & Year & Pathogen & Produce & $\begin{array}{c}\text { Cases } \\
\text { (deaths) }\end{array}$ \\
\hline Canada & 2005 & Salmonella & Mung bean & 592 \\
\hline USA & 2005 & Salmonella & Tomatoes & 459 \\
\hline USA & 2006 & E. coli $0157: H 7$ & Spinach & $199(3)$ \\
\hline Australia & 2006 & Salmonella & Alfalfa sprouts & 125 \\
\hline USA, Canada & 2006 & Salmonella & Fruit salad & 41 \\
\hline USA & 2006 & Salmonella & Tomatoes & 183 \\
\hline USA & 2006 & E. coli O157:H7 & Lettuce & 81 \\
\hline Australia & 2006 & Salmonella & Cantaloupe & 115 \\
\hline USA & 2006 & E. coli O157:H7 & Spinach & 22 \\
\hline Europe & 2007 & Salmonella & Baby spinach & 354 \\
\hline $\begin{array}{l}\text { North America, } \\
\text { Europe }\end{array}$ & 2007 & Salmonella & Basil & 51 \\
\hline Australia, Europe & 2007 & Shigella sonnei & Baby carrots & 230 \\
\hline Europe & 2007 & Salmonella & Alfalfa sprouts & 45 \\
\hline USA, Canada & 2008 & Salmonella & Peppers & $1442(2)$ \\
\hline USA, Canada & 2008 & E. coli $0157: H 7$ & Lettuce & 134 \\
\hline UK & 2008 & Salmonella & Basil & 32 \\
\hline USA & 2008 & Salmonella & Cantaloupe & 51 \\
\hline USA, Canada & 2008 & Salmonella & Peanut butter & $714(9)$ \\
\hline USA & 2009 & Salmonella & Alfalfa sprouts & 235 \\
\hline USA & 2010 & E. coli O157:H7 & Lettuce & 26 \\
\hline USA & 2010 & Salmonella & Alfalfa sprouts & 44 \\
\hline USA & 2010 & L. monocytogenes & fresh cut celery & $10(5)$ \\
\hline USA & 2011 & Salmonella & Alfalfa & 140 \\
\hline USA & 2011 & Salmonella & Cantaloupe & 20 \\
\hline USA & 2011 & Salmonella & Papaya & 106 \\
\hline Europe & 2011 & E. coli O157:H7 & Vegetable & $3911(47)$ \\
\hline USA & 2011 & L. monocytogenes & Cantaloupe & $146(31)$ \\
\hline USA & 2011 & E. coli $0157: H 7$ & Strawberries & $15(1)$ \\
\hline USA & 2011 & E. coli $0157: H 7$ & Lettuce & 60 \\
\hline
\end{tabular}

EU regulation establishes some pathogenic microorganisms as the unique microbiological criteria. Then, fresh-cut and fruit and vegetables beverages with mild heat treatments or non-thermal treatments are regulated by the EU Regulation 
1441/2007 (2007). Table 7 includes the applicable microbial criteria of the latter Regulation.

Table 7. Food safety criteria applied to the fresh-cut products food (Regulation EC 1441/2007, 2007).

\begin{tabular}{|c|c|c|c|c|c|c|}
\hline \multirow{2}{*}{ Food category } & \multirow{2}{*}{ Microorganism } & \multicolumn{2}{|c|}{$\begin{array}{l}\text { Sampling } \\
\text { plan }{ }^{1}\end{array}$} & \multicolumn{2}{|c|}{ Limits $^{2}$} & \multirow{2}{*}{$\begin{array}{l}\text { Stage where the } \\
\text { criterion applies }\end{array}$} \\
\hline & & $\mathrm{n}$ & $\mathrm{c}$ & $\mathrm{m}$ & $\mathrm{M}$ & \\
\hline $\begin{array}{l}\text { Pre-cut fruit and } \\
\text { vegetables } \\
\text { (ready-to-eat). }\end{array}$ & E. coli & 5 & 2 & $\begin{array}{c}100 \\
\mathrm{CFU} \mathrm{^{-1 }}\end{array}$ & $\begin{array}{l}1,000 \\
\mathrm{CFU} \mathrm{g}^{-1}\end{array}$ & Manufacturing process. \\
\hline $\begin{array}{l}\text { Pre-cut fruit and } \\
\text { vegetables } \\
\text { (ready-to-eat). }\end{array}$ & Salmonella & 5 & 0 & \multicolumn{2}{|c|}{ Absence in $25 \mathrm{~g}$} & $\begin{array}{l}\text { Products placed on the market } \\
\text { during their shelf- life. }\end{array}$ \\
\hline \multirow{2}{*}{$\begin{array}{l}\text { Ready-to-eat } \\
\text { foods able to } \\
\text { support the } \\
\text { growth of Listeria } \\
\text { monocytogenes, } \\
\text { other than those } \\
\text { intended for } \\
\text { infants and for } \\
\text { special medical } \\
\text { purposes. }\end{array}$} & \multirow[b]{2}{*}{ L. monocytogenes } & \multirow[b]{2}{*}{5} & \multirow[b]{2}{*}{0} & \multicolumn{2}{|c|}{$100 \mathrm{CFU} \mathrm{g}^{-13}$} & $\begin{array}{l}\text { Products placed on the market } \\
\text { during their shelf- life. }\end{array}$ \\
\hline & & & & \multicolumn{2}{|c|}{ Absence in $25 \mathrm{~g}^{4}$} & $\begin{array}{l}\text { Before the food has left the } \\
\text { immediate control of the food } \\
\text { business operator. }\end{array}$ \\
\hline \multicolumn{7}{|c|}{$\begin{array}{l}\text { (1) } \mathrm{n}=\text { number of units comprising the sample; } \mathrm{c}=\text { number of sample units giving values between } \mathrm{m} \text { and } \mathrm{M} / /(2) \\
\text { For points } 1.1-1.25 ; \mathrm{m}=\mathrm{M} \text {. // (3) This criterion shall apply if the manufacturer is able to demonstrate, to the } \\
\text { satisfaction of the competent authority, that the product will not exceed the limit } 100 \mathrm{CFU} / \mathrm{g} \text { throughout the shelf- } \\
\text { life. The operator may fix intermediate limits during the process that must be low enough to guarantee that the limit } \\
\text { of } 100 \mathrm{CFU} / \mathrm{g} \text { is not exceeded at the end of shelf-life. // (4) This criterion shall apply to products before they } \\
\text { have left the immediate control of the producing food business operator, when he is not able to } \\
\text { demonstrate, to the satisfaction of the competent authority, that the product will not exceed the limit of } 100 \mathrm{CFU} / \mathrm{g} \\
\text { throughout the shelf-life. }\end{array}$} \\
\hline
\end{tabular}


OBJECTIVES 


\section{OBJETIVES}

The general objective of this research is to optimize several processes to develop new fresh and processed human food from native varieties of three legumes species (faba beans, peas and cowpeas) with high nutritional quality and high bioactive compounds content. Such legumes species are well adapted to several European climates. In that way, legumes of local origin and rich in proteins could be easily included in daily human diet.

The general objective can be achieved through the following specific objectives:

1. Optimize minimal processing and packaging technologies for faba beans, peas and cowpeas to be microwaved during the refrigerated shelf life serving as a 'ready to cook and eat product'.

2. Evaluate the new elaborates in relation of their physical, biochemical, microbiological and sensory characteristics throughout a refrigerated shelf life.

3. Guarantee the nutritional value of these foods, as well as to reduce or eliminate the presence of anti-nutritional factors.

4. Study of the use of alternative chemical and physical disinfectants to $\mathrm{NaOCl}$ during legumes minimal processing.

5. Study of the use of edible coatings to avoid quality looses in the developed minimally processed products. 
CHAPTERS 


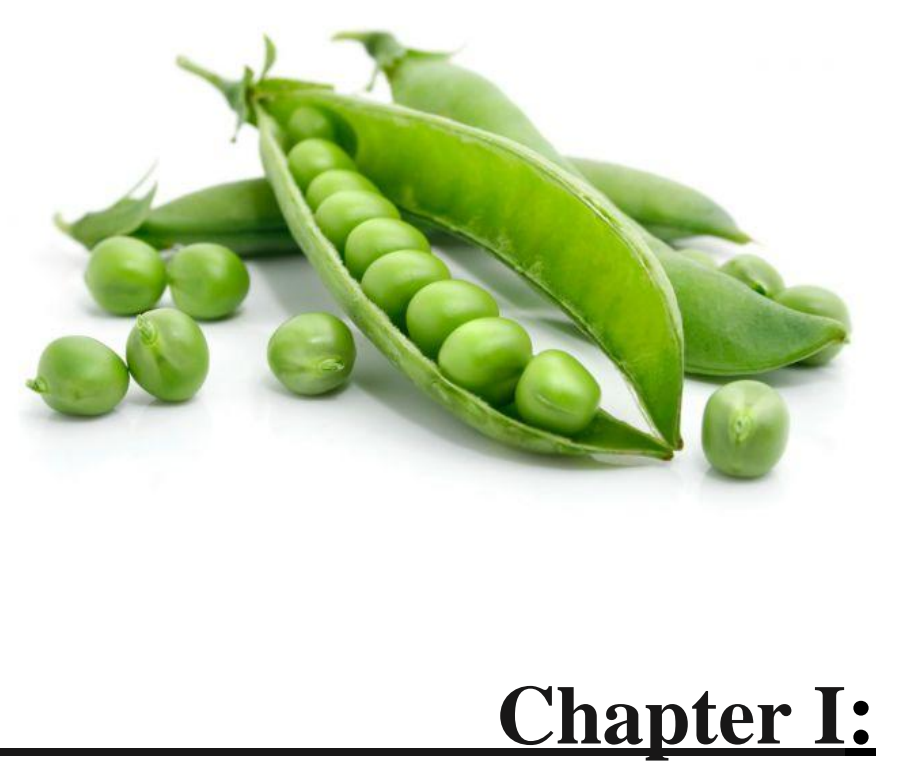

Immature pea seeds: Effect of storage under modified atmosphere packaging and sanitation with acidified sodium chlorite

Collado, E., Klug, T.V, Martínez-Sánchez, A., Artés-Hernández, F., Aguayo, E., Artés, F., Fernández, J.A., Gómez, P.A.

Journal of the Science of Food and Agriculture. 2017. 97: 4370-4378.

http://dx.doi.org/10.1002/jsfa.8513 


\section{ABSTRACT}

Peas (Pisum sativum L. var. saccharatum) are an important source of protein, carbohydrates, vitamins and minerals. Pods are harvested before physiological maturity and stored at temperatures near $0^{\circ} \mathrm{C}$. Due to their very high respiration rate, and even when classified as non-climacteric product, loss of quality is fast. Most studies conducted on fresh peas have dealt with the fresh pod but very little information is available on the optimum storage conditions of immature pea seeds, which are well adapted to be prepared as a minimally processed product. Appropriate sanitation is a priority for extending the shelf life and promoting the consumption of immature pea seeds, as processing accelerates quality deterioration and microbial growth. The effects of sanitation with chlorine (100 ppm, pH 6.5) or alternatively with acidified sodium chlorite (300 ppm, pH 1.8) and passive modified atmosphere packaging on overall quality of fresh pea seeds (var. Lincoln) were assessed during storage at 1 and $4^{\circ} \mathrm{C}$. After 12 days, atmospheres within packages were $8 \mathrm{kPa} \mathrm{CO}_{2} / 12 \mathrm{kPa} \mathrm{O}_{2}$ and $11 \mathrm{kPa}$ $\mathrm{CO}_{2} / 10 \mathrm{kPa} \mathrm{O}$ at 1 and $4^{\circ} \mathrm{C}$, respectively. Compared with the initial microbial load, samples stored at $1^{\circ} \mathrm{C}$ showed an increase of $1 \log \mathrm{CFU} \mathrm{g^{-1 }}$ in psychrophiles when treated with $\mathrm{NaOCl}$, whereas no increase of note occurred with ASC. In general, microbial counts were always below $3 \log \mathrm{CFU} \mathrm{g}{ }^{-1}$ for all the treatments. Greenness and vitamin $\mathrm{C}$ had decreased, especially in the $\mathrm{NaOCl}$-disinfected samples. Total phenols and antioxidant capacity were not affected by disinfection. Proteins levels fell by around $27 \%$, regardless of the sanitizer and storage temperature. Low temperature storage allowed obtaining a high quality product even after 12 days of storage, being ASC a good alternative to chlorine. In conclusion, immature pea seeds could be stored for 14 days at $1-4^{\circ} \mathrm{C}$ under MAP with only minor quality changes. Disinfection with ASC resulted in better sensory quality, higher content of vitamin C and lower psychrophile counts. 


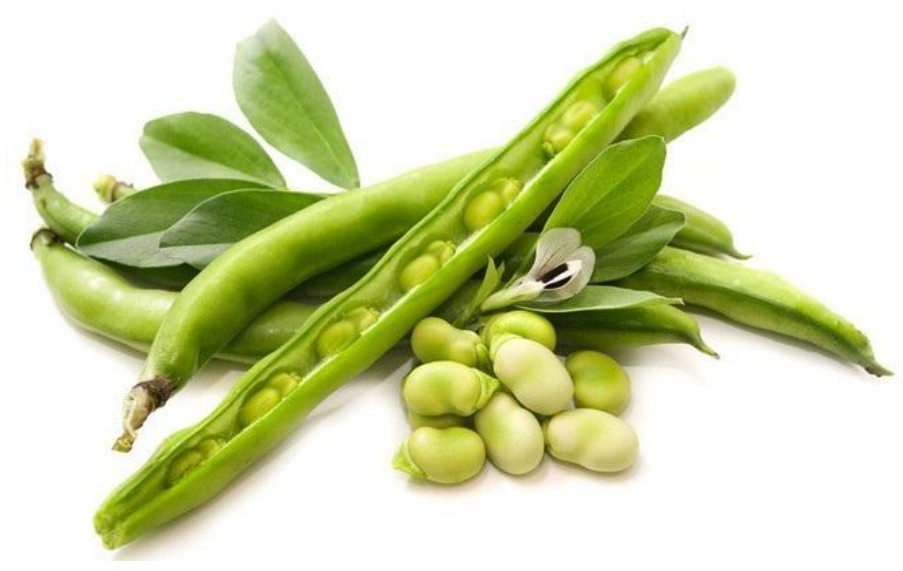

Chapter II:

Nutritional and quality changes of minimally processed faba (Vicia faba L.) beans during storage: Effects of domestic microwaving

Collado, E., Venzke Klug, T., Martínez-Hernández, G.B Artés-Hernández, F., Martínez-Sánchez, A., Aguayo, E., Artés, F., Fernández, J.A., Gómez, P.A.

Postharvest Biology and Technology. 2019. 151:10-18.

https://doi.org/10.1016/j.postharvbio.2019.01.008 


\section{ABSTRACT}

Numerous studies have shown that regular consumption of vegetables is associated with beneficial properties for human health. At the same time, today, there by consumers an interest in functional, healthy and ready to eat foods. Currently they are developing new ways of presenting the bean as minimally processed fresh food as well as its cooked in microwave, trying to encourage consumption, given its advantages as part of a nutritious and healthy diet. Disinfection prior to packaging fresh immature seeds is done usually with sodium hypochlorite. In this study the effect of two alernative treatments were analyzed: the effect of different sanitizers (an edible coating (EC) based on sucrose fatty acid esters, and UV-C $\left(3 \mathrm{~kJ} \mathrm{~m}^{-2}\right)$, compared with a control consisting of a conventional $\mathrm{NaOCl}$ washing (CTRL)) on the quality changes of fresh-cut faba (Vicia faba L.) seeds stored for $10 \mathrm{~d}$ at $4{ }^{\circ} \mathrm{C}$. Additionally, domestic cooking of samples was assessed by periodically microwaving ( $3 \mathrm{~min}, 700 \mathrm{~W}$ ) during fresh-cut samples storage to obtain a ready-to-eat product. Sensorial attributes, microbial growth, and evolution of vitamin C, total phenolics content (TPC), sugars and tannins were studied on uncooked and cooked faba beans. These analyzes were performed for minimally processed product during storage at $5^{\circ} \mathrm{C}$ for 10 days, so to this same product immediately after microwave cooking. The modified atmosphere gas composition at the steady was the same for all treatments. Sensorial attributes were above the limit of acceptability for fresh and microwaved beans, subjected to treatment with UV-C light and antibrowing edible coating Naturcover P until the last day of storage. Beans treated with sodium hypochlorite maintained their sensory acceptance until day 7, both in fresh and microwaved product. The EC treatment better retained vitamin $\mathrm{C}$, total phenolics content (TPC) and tannins, while UV-C better maintained the sugars levels of samples. EC and UV-C controlled mesophilic and enterobacteria growth with 1 and 2-log units lower contents than CTRL after $10 \mathrm{~d}$ at $4{ }^{\circ} \mathrm{C}$. Microwaving reduced the microbial loads below detection limits. EC or UV-C treatments extended the shelf-life of fresh-cut faba seeds from 7 to 10 days at $4^{\circ} \mathrm{C}$ comparing with CTRL. As expected, microwaving decreased the bioactive compounds contents, but retained the quality of faba seeds allowing to obtain a ready-to-eat tasteful food. A UV-C pretreatment $\left(3 \mathrm{~kJ} \mathrm{~m}^{-2}\right)$ or a conventional $\mathrm{NaOCl}$ sanitizing step plus an edible coating (Naturcover® P; EC) during processing of fresh-cut faba seeds could be considered as important tools to improve their sensory, microbial and nutritional quality. Our results suggest that a typical quality loss during shelf-life can be reduced by using such coadjutants in the processing steps. 


\section{Chapter III:}

Quality changes in nutritional traits of fresh-cut and then microwaved cowpea seeds and pods

Collado, E., Venzke Klug, T., Artés-Hernández, F., Aguayo, E., Artés, F., Fernández, J.A., Gómez, P.A.

Food and Bioprocess Technology. 2019. 12: 338-346.

http://dx.doi.org/10.1007/s11947-018-2214-2 


\section{ABSTRACT}

Numerous studies show that regular vegetable consumption is associated with beneficial properties for human health. At the same time, there is an interest in functional, healthy and ready-to-consume foods from consumers. In this sense, cowpea (Vigna unguiculata) is an excellent source of many essential nutrients, including proteins and aminoacids of vegetable origin, complex carbohydrates, minerals, fiber, vitamins, and other bioactive compounds, and is low in calories and fat. Dry grains are the most common produce used for human food, but leaves and immature seeds and pods are also consumed.In this context, the consumption of cowpea beans as a fresh food minimally processed, as well as, cooked in microwaves, can be alternatives to stimulate the consumption of legumes. The objective of this work was to evaluate the quality of fresh-cut cowpea prepared to be eaten raw (immature seeds) or microwaved (seeds and pods). Fresh cowpea pods were washed with $\mathrm{NaOCl}\left(150 \mathrm{mg} \mathrm{L}^{-1}, \mathrm{pH} 6.5\right)$ and stored for 21 days at $8^{\circ} \mathrm{C}$ under modified atmosphere packaging. Additionally, seeds obtained from hulled pods were equally disinfected, packaged, and stored for 7 days at $4^{\circ} \mathrm{C}$. The total phenolic content (TPC), total antioxidant capacity (TAC), sugars (raffinose, sucrose, glucose), and sensory attributes were evaluated in microwaved pods (700 W, 1 min), fresh seeds, and microwaved seeds. TPC and TAC increased after microwaving in both seeds and pods. Sucrose and glucose concentrations increased after microwaving, while raffinose was not detected after cooking. According to sensory quality, fresh $\left(4^{\circ} \mathrm{C}\right)$ and microwaved seeds maintained all the above attributes above the limit of usability until day 7 , while pods were edible for up to 14 days if kept at $8^{\circ} \mathrm{C}$. These results indicate that cowpea seeds and pods (fresh-cut and then microwaved) are feasible and practical products to stimulate legume consumption from local landraces, especially in the absence of raffinose, which improves product digestibility. 


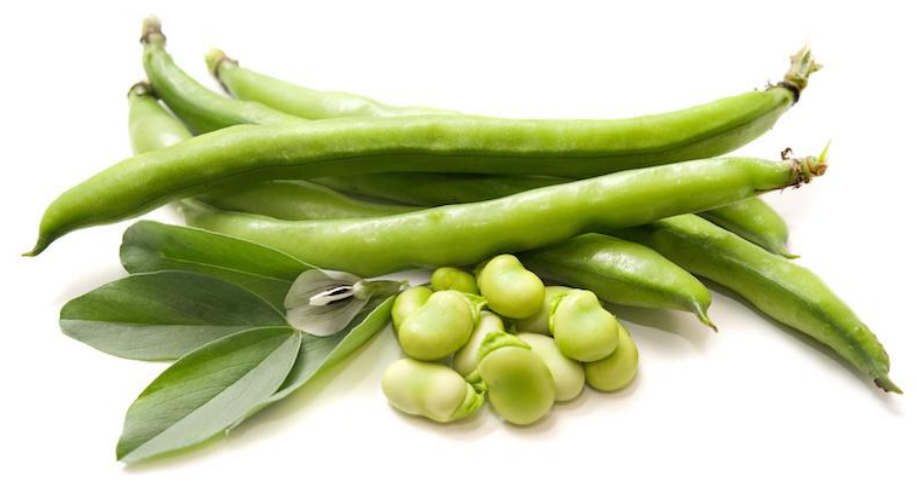

Chapter IV:

$U V$-C pretreatment of fresh-cut faba beans (Vicia faba) for shelf life extension: Effects of domestic microwaving for consumption

Collado, E., Venzke Klug, T., Martínez-Hernández, G. B., Artés-Hernández, F., Martínez-Sánchez, A., Aguayo, E., Artés, F., Fernández, J.A., Gómez, P.A.

Food Science and Technology International. 2019. In press DOI: 10.1177/1082013219873227. 


\section{ABSTRACT}

Faba beans (Vicia faba L.) are an important source of protein, carbohydrates, vitamins and minerals. However, there are not many studies about the physiological behavior of immature fabas subjected to minimal processing, preservation and cooking. Currently they are developing new ways of presenting the faba been seeds as minimally processed fresh food as well as its cooked in microwave, trying to encourage consumption, given its advantages as part of a nutritious and healthy diet. Sanitation is one of the most critical steps in the fresh-cut production, due to the effects of microbial load on quality, safety and shelf-life of the final product. The present studied evaluated the effect of different sanitizers $\left(\mathrm{NaOCl}\right.$, and UV-C $\left(3 \mathrm{~kJ} \mathrm{~m}^{-2}\right.$, UV) and passive modified atmosphere packaging on the sensory and microbial quality, and bioactive and anti-nutritional content of fresh-cut faba beans during storage at $5^{\circ} \mathrm{C}$. After 10 days, the atmospheres within the packages were $12.5 \mathrm{kPa} \mathrm{CO} / 5.3 \mathrm{kPa} \mathrm{O}_{2}$ in the case of seeds treated with $\mathrm{NaOCl}$ and $22.5 \mathrm{KPa} \mathrm{CO}_{2} / 4.2 \mathrm{KPa} \mathrm{O}_{2}$, in the case of seeds treated with UV-C. Sensorial attributes were above the limit of acceptability for fresh and microwaved faba bean, subjected to treatment with UV-C light until the last day of storage. Beans treated with $\mathrm{NaOCl}$ maintained their sensory acceptance until day 7 , both in fresh and microwaved product. The microbial load was low at the end of storage, although $\mathrm{NaOCl}$ showed the highest microbial counts for mesophiles, psycrophiles and enterobacteria. UV-C did not negatively affect the total antioxidant capacity of samples during storage. The phytic acid and raffinose contents decreased after 10 days, without influence of the UV-C treatment. Microwaving reduced the phytic acid and condensed tannins contents in those samples stored for up to six days, with low microwaving effect in the last storage days. Nevertheless, UV-C improved the condensed tannins reductions through storage compared with non-irradiated samples. In conclusion, the UV-C treatment of fresh-cut faba beans extended shelf life to 10 days without affecting the antioxidant capacity and with a reduction in anti- nutritional compounds achieved after domestic microwaving. 
CONCLUSIONS 


\section{CONCLUSIONS}

In order to develop new legume products for both fresh and microwave cooking, several minimal processing methods and techniques have been studied, evaluating the use of $\mathrm{NaOCl}$ alone or in combination with edible coatings, or alternatively with chemical (ASC) or physical (UV-C) disinfectants.

The main general conclusions of the current $\mathrm{PhD}$ Dissertation are as follows:

- Faba beans:

- A pretreatment with UV-C (3 $\left.\mathrm{kJ} \mathrm{m}^{-2}, 90 \mathrm{~s}\right)$ or a conventional $\mathrm{NaOCl}(150 \mathrm{ppm})$ sanitizing step plus an EC based of sucrose fatty acid esters during fresh-cut processing of faba seeds could be important technological tools to improve their sensory, microbial and nutritional quality.

- Fresh seeds can be microwaved within the package used for fresh storage under MAP. Microwaving ( $700 \mathrm{~W}, 3 \mathrm{~min}$ ) decreased the concentration of bioactive compounds, but retained the quality of seeds allowing to obtain a ready to eat tasteful food.

- Fresh-cut faba seeds treated with EC or UV $\left(3 \mathrm{~kJ} \mathrm{~m}^{-2}, 90 \mathrm{~s}\right)$ treatments extended the shelf life of from 7 to 10 days at $4^{\circ} \mathrm{C}$ regarding $\mathrm{NaOCl}(150 \mathrm{ppm})$ treatment.

- UV-C $\left(3 \mathrm{~kJ} \mathrm{~m}^{-2}, 90 \mathrm{~s}\right)$ treatment in fresh-cut faba bean samples showed lower microbial loads compared to disinfection with $\mathrm{NaOCl}$, after 10 days at $5^{\circ} \mathrm{C}$.

- A conventional $\mathrm{NaOCl}(150 \mathrm{ppm})$ sanitizing step plus an EC reduced the microbial load in fresh faba beans seeds after 10 days at $4^{\circ} \mathrm{C}$, although $\mathrm{NaOCl}$ samples showed the highest natural microflora counts.

- The UV-C treatment did not negatively affect the TAC of faba bean seeds during storage compared to the non-UV-C exposed samples, and showed the highest sugars content values compared to samples treated with $\mathrm{NaOCl}$ or EC.

- The EC treatment showed a positive effect on vitamin C, TPC and tannins content retention in both fresh and microwaved faba bean seeds.

- The phytic acid, raffinose and condensed tannins contents decreased in faba beans samples after 10 days of storage.

- UV-C improved the condensed tannins reductions through storage compared with non-irradiated faba bean seeds samples. 
- A reduction of condensed tannins and raffinose was observed after microwaving UV-C-treated faba bean seeds previously stored for 10 days.

- Microwaving reduced the phytic acid and condensed tannins contents in faba bean seeds.

- Peas:

- The use of ASC (300 ppm) as a sanitizer during fresh-cut processing of fresh pea seeds is a good alternative to $\mathrm{NaOCl}\left(100 \mathrm{ppm}, \mathrm{pH} 6.5,2 \mathrm{~min}, 4^{\circ} \mathrm{C}\right)$ since it led to better sensory quality and a higher nutritional quality.

- Immature green pea seeds disinfected with $\mathrm{NaOCl}(100 \mathrm{ppm})$ or ASC (300 ppm) can be stored for 14 days under MAP $\left(8 \mathrm{kPa} \mathrm{CO} / 12 \mathrm{kPa} \mathrm{O}_{2}\right.$ and $11 \mathrm{kPa} \mathrm{CO}_{2} /$ $10 \mathrm{kPa} \mathrm{O}_{2}$ at 1 and $4^{\circ} \mathrm{C}$ ) at temperatures between 1 and $4^{\circ} \mathrm{C}$ without any noticeable quality loss.

- Disinfection of fresh pea seeds with ASC (300 ppm) showed a lower psychrophile counts than disinfection with $\mathrm{NaOCl}(100 \mathrm{ppm})$.

- ASC disinfection in pea seeds not affected the TAC and TPC, while the vitamin $\mathrm{C}$ content was higher.

- Cowpea:

- Cowpea seeds and pods (fresh-cut and then microwaved) are feasible and practical products to stimulate legume consumption.

- Immature cowpea seeds and pods, disinfected with $\mathrm{NaOCl}$, could be stored for at least 7 and 14 days, respectively, at 4 and $8^{\circ} \mathrm{C}$ under MAP $\left(23 \mathrm{kPa} \mathrm{CO}_{2} / 1.5\right.$ $\mathrm{kPa} \mathrm{O}_{2}$ and $19 \mathrm{kPa} \mathrm{CO}_{2} / 1.2 \mathrm{kPa} \mathrm{O}_{2}$ for fresh seeds and pods, respectively).

- Fresh seeds and pods can be microwaved within the package used for fresh storage under MAP. Microwaving ( $700 \mathrm{~W}, 1 \mathrm{~min})$ decreased the concentration of bioactive compounds, but retained the quality of seeds and pods allowing to obtain a ready to eat tasteful food.

- TPC and TAC increased after microwaving in both cowpea seeds and pods. Sucrose and glucose concentrations increased after microwaving, while raffinose was not detected after cooking.

- Heating negatively affected the total phenolic content and antioxidant capacity in cowpea seeds and pods. 
Since the general objective of this research is to optimize several processes to develop new fresh and processed foods from native varieties of three legume species (faba, pea and cowpea), to stimulate the consumption of these in the daily human diet, both for fresh and microwave consumption, It can be said that with the use of various minimal processing techniques using $\mathrm{NaOCl}$ alone or in combination with edible coatings, or alternatively with chemical (ASC) or physical (UV-C) disinfectants, vegetable products with high nutritional quality and high content of bioactive compounds, fresh and ready to eat, can be obtained. 


\section{SCIENTIFIC PUBLICATIONS DERIVED FROM THIS PhD DISSERTATION}

Original papers published in peer-reviewed journals included in the Journal Citation Reports (JCR) of the Institute for Scientific Information (ISI)

- Collado, E., Artés-Hernández, F., Navarro, L., Artés, F., Aguayo, E., Fernández, J.A., Gómez, P.A. (2016). Overall quality of minimally processed pea seeds. In: Proc. III ISHS International Conference on Fresh-cut Produce. University of California, Davis, California, USA. Eds.: M. Cantwell. Edit: ISSH. ISBN: 978-94-6261-129-0. ISSN: 0567-7572. Acta Horticulturae. 1441: 137144. https://doi.org/10.17660/ActaHortic.2016.1141.15.

- Collado, E., Klug, T.V, Martínez-Sánchez, A., Artés-Hernández, F., Aguayo, E., Artés, F., Fernández, J.A. and Gómez, P.A. (2017). Immature pea seeds. Effect of storage under modified atmosphere packaging and sanitation with acidified sodium chlorite. Journal of the Science of Food and Agriculture. 97: 4370-4378. http://dx.doi.org/10.1002/jsfa.8513.

- Collado, E., Artés-Hernández, F., Navarro, L., Artés, F., Aguayo, E., Fernández, J.A. and Gómez, P.A. (2018). Overall quality of minimally processed faba bean seeds stored in MAP. Acta Horticulturae. 1194: 513-518. https://doi.org/10.17660/ActaHortic.2018.1194.75.

- Collado, E., Venzke Klug, T., Artés-Hernández, F., Aguayo, E., Artés, F., Fernández, J.A., Gómez, P.A. (2019). Quality changes in nutritional traits of fresh-cut and then microwaved cowpea seeds and pods. Food and Bioprocess Technology. 12: 338-346. http://dx.doi.org/10.1007/s11947-0182214-2.

- Collado, E., Venzke Klug, T., Martínez-Hernández, G.B., Artés-Hernández, F., Martínez-Sánchez, A., Aguayo, E., Artés, F., Fernández, J.A., Gómez, P.A. (2019). UV-C pretreatment of fresh-cut faba beans (Vicia faba) for shelf life extension: Effects of domestic microwaving for consumption. Food Science and Technology International. In press. https://doi.org/10.1177/1082013219873227. 
- Collado, E., Venzke Klug, T., Martínez-Hernández, G.B Artés-Hernández, F., Martínez-Sánchez, A., Aguayo, E., Artés, F., Fernández, J.A., Gómez, P.A. (2019). Nutritional and quality changes of minimally processed faba (Vicia faba L.) beans during storage: Effects of domestic microwaving. Postharvest Biology and Technology. https://doi.org/10.1016/j.postharvbio.2019.01.008.

\section{SCIENTIFIC PUBLICATIONS RESULTING FROM THE TRAINING PERIOD}

- Klug, T.V., Martínez-Sánchez, A., Gómez, P.A., Collado, E., Aguayo, E., Artés, F. and Artés-Hernández, F. (2017). Improving quality of an innovative pea puree by high hydrostatic pressure. Journal of the Science of Food and Agriculture. 97: 4362-4369, doi: 10.1002/jsfa.8454.

- Klug, T.V., Collado, E., Martínez-Sánchez, A., Gómez, P.A., Aguayo, E., Otón, M., Artés, P. and Artés-Hernández, F. (2018). Innovative quality improvement by continuous microwave processing of a faba beans pesto sauce. Food and Bioprocess Technology. 11:561-571, doi: 10.1007/s11947-017-2024-y.

- Klug, T.V., Martínez-Hernández, G.B., Collado, E., Artés, F. and ArtésHernández, F. (2018). Effect of microwave and high pressure processing on quality of an innovative broccoli hummus. Food and Bioprocess Technology. 11: 1464-1477, doi: 10.1007/s11947- 018-2111-8.

- Klug, T.V., Collado, E., Martínez-Hernández, G., Artés, F. and ArtésHernández, F. (2018). Effect of stevia supplementation of kale juice spheres on their quality changes during refrigerated shelf life. Journal of the Science of Food and Agriculture. 99 (5): 2384-2392, doi: 10.1002/jsfa.9445.

\section{Original scientific papers published in JCR-ISI not included journals}

- Gómez, P.A., Collado, E., Venzke Klug, T., Artés-Hernández, F., Aguayo, E., Martínez-Sánchez, A., Artés, F., Fernández, J.A. (2017). Nuevos alimentos de leguminosas autóctonas para promover su consumo seguro y de calidad en un entorno sostenible. Accepted by the popular magazine: CTC. Revista de Agroalimentación e Industrias afines. 


\section{International Congress}

- Artés-Hernández, F., Collado, E., Klug, T.V., Aguayo, E., Artés, F., Gómez, P.A. 2018. Evolución de la calidad de semillas y vainas de Caupí mínimamente procesadas en fresco y microondadas. XII Simposio Nacional y X Ibérico de Maduración y Postcosecha. Badajoz, 4-7 junio 2018.

- Collado, E., Artés-Hernández, F., Navarro, L., Artés, F., Aguayo, E., Fernández, J.A., Gómez, P.A. 2016. Overall quality of minimally processed pea seeds. In: Proc. III ISHS International Conference on Fresh-cut Produce. University of California, Davis, California, USA. Eds.: M. Cantwell. Edit: ISSH. ISBN: 97894-6261-129-0. ISSN: 0567-7572. Acta Hort., 1441. Pp. 137-144. doi 10.17660/ActaHortic.2016.1141.15.

- Collado, E., Artés-Hernández, F., Aguayo, E., Navarro, L., Artés, F., Fernández, J.A. and Gómez, P.A. 2016. Overall quality of minimally processed faba bean seeds stored in MAP. International Postharvest Symposium. Cartagena, Spain, 21-24/6/2016.

- Collado E., Armero, E., Gómez, P.A. Development of innovative food with high nutritional value from native legumes. In: Proceedings of the 4th Workshop on Agri-Food research: WiA.15. Cartagena: Universidad Politécnica de Cartagena, CRAI Biblioteca, 2016. ISBN: 978-84-608-5399-2. Pp 236-238. Open access: http://repositorio.upct.es/handle/10317/5290

- Collado, E., Armero, E., Artés-Hernández, F., Aguayo, E., Artés, F., Fernández, J.A., Gómez, P.A. 2017. Vitamin C and microbial quality of minimally fresh processed pea seeds stored in modified atmosphere packaging. In: Proceedings of the 5th Workshop on Agri-Food Research WiA-16. Eds: F. ArtésHernández, J.A. Fernández-Hernández, J. Calatrava, E. Aguayo, J.J. Alarcón, J.E. Cos. Editorial: CRAI Biblioteca, Universidad Politécnica de Cartagena, Murcia, España. ISBN: 978-84-16325-29-0. 223 pp. Pp. 48-51. Open access: http://hdl.handle.net/10317/5558.

- Collado E., Fernández J.A., Vivancos N., Moya F. and Armero E. 2016. Pea straw: an advantageous co-product in dairy goat diets Second International 
Legume Society Conference. 2016: Legumes for a sustainable world. Troia, Portugal, 12-14/10/2016

- Collado, E., Artés Hernández, F., Artés, F., Aguayo, E., Fernández, J.A. and Gómez, P.A. 2016. Sustainable sanitation methods for keeping overall quality of minimally processed faba seeds. Second International Legume Society Conference 2016: Legumes for a sustainable world. Troia, Portugal, 12$14 / 10 / 2016$

- Collado, E., Artés-Hernández, F., Aguayo, E., Artés, F. and Gómez, P.A. 2016. Quality changes of minimally processed fresh and microwave cooking of faba bean seeds. IX Simpósio Ibérico Maturaçao e pós-colheita, Libro de Resumos. ISBN: 978-972-8936-24-2. p. 82. Lisboa, Portugal, 2-4/11/2016.

- Collado, E., Klug, T. V., Artés-Hernández, F., Aguayo, E., Artés, F., Fernández, J.A. and Gómez, P.A. 2017. Avaliação da qualidade de grãos de feijão-fava minimamente processados e microondados durante armazenamento. $\mathbf{1}^{\circ}$ Congresso Luso-Brasileiro de Horticultura. Lisboa, Portugal, 1-4/11/2017.

- Collado, E., Klug, T.V., Artés-Hernández, F., Aguayo, E., Artés, F., Fernández, J.A. and Gómez, P.A. 2017. Quality changes of fresh and then microwaved minimally processed faba seeds. International Conference LegatoEurolegume. Novi Sad, Serbia, 27-28/9/2017.

- Collado, E., Klug, T.V., Artés-Hernández, F., Aguayo, E., Artés, F., Fernández, J. and Gómez, P.A. 2017. Cambios en la calidad de guisantes mínimamente procesados en fresco y su respuesta al cocinado con microondas. IX Congreso Iberoamericano de Tecnología Postcosecha y Agroexportaciones. Santiago, Chile, 29/11-01/12/2017.

- Collado, E., Venzke Klug, T., Artés-Hernández, F., Aguayo, E., MartínezSánchez, A., Artés, F., Gómez, P. 2018. Cambios en la calidade de semillas de haba mínimamente procesadas y microondadas. In: Proceedings of the 6th Workshop on Agri-Food Research WiA-17. Editores: F. Artés-Hernández, J.E. Cos, J.A. Fernández-Hernández, J. Calatrava, E. Aguayo, J.J. Alarcón, M. Egea. Editorial: CRAI Biblioteca, Universidad Politécnica de Cartagena, 
Murcia, España. ISBN: 978-84-16325-64-1. 208 pp Pp. 19-22. Open access: http://hdl.handle.net/10317/6706

- Collado, E., Venzke Klug, T., Artés-Hernández, F., Aguayo, E., MartínezSánchez, A., Artés, F., Gómez, P. 2019. Cambios en la calidad de semillas de haba mínimamente procesadas tratadas con diferentes desinfectantes. In: Proceedings of the 7th Workshop on Agri-Food Research WiA-18. Editors: Artés-Hernández, F; Fernández-Hernández, J.A.; Cos, J.E., Alarcón, J.J.; EgeaCortines. M.; Aguayo, E. Editorial: Editorial: CRAI Biblioteca, Universidad Politécnica de Cartagena, Cartagena, Murcia, Spain. ISBN: 978-84-16325-89-4. 34-37. 167 pp. Open Access. http://hdl.handle.net/10317/7652

- Klug, T.V, Collado, E., Martínez-Sánchez, A., Artés-Hernández, F., Gómez, P.A., Aguayo, E., Artés, F. 2016. Sensory and microbial quality of a pea puree processed under conventional or microwave treatment. VI Congreso Internacional de Ingeniería Química, Biotecnológica y Alimentaria (CIIQBA, 2016), La Habana, Cuba. 21-25/11/2016.

- Klug, T.V., Collado, E., Martínez-Sánchez, E., Artés-Hernández, F., Gómez, P.A., Aguayo, E. and Artés, F. 2017. Avaliação da qualidade de feijão caupi minimamente processado e microondado. $1^{\circ}$ Congresso Luso-Brasileiro de Horticultura. Lisboa, Portugal, 1-4/11/2017. 


\section{LIST OF REFERENCES}

Acuña, M.L. (2011). Evaluación agronómica de la fecha de siembra en habas determinadas (Vicia faba L. var. Major) en Valdivia, Región de Los Ríos. Tesis Doctoral. Escuela de Agronomía. Universidad Austral de Chile. 259 pp.

Adamidou, S., Nengas, I., Grigorakis, K., Nikolopoulou, D. and Jauncey, K. (2011). Chemical composition and antinutritional factors of field peas (Pisum sativum), chickpeas (Cicer arietinum), and faba beans (Vicia faba) as affected by extrusion preconditioning and drying temperatures. Cereal Chemistry. 88(1): 80-86.

Adelakun, O. and Duodu, G. (2017). Identification and Quantification of Phenolic Compounds and Bioactive Properties of Sorghum-cowpea-based Food Subjected to an In vitro Digestion Model. European Journal of Nutrition \& Food Safety. 7: 5766.

Adjei-Fremah, S., Jackai, L.E.N. and Worku, M. (2015). Analysis of phenolic content and antioxidant properties of selected cowpea varieties tested in bovine peripheral blood. Journal of Animal and Veterinary Science. 10(4): 235.245.

Aguayo, E., Allende, A. and Artés, F. (2003). Keeping quality and safety of minimally fresh processed melon. European Food Research and Technology. 216: 494-499.

Agüero, M., Pereda, J., Roura, S., Moreira, M. and del Valle, C. (2005). Sensory and biochemical changes in Swiss chard (Beta vulgaris) during blanching. Lwt - Food Science and Technology. 38: 772-778.

Ahn, H.J., Kim, J.H., Yook, H.S. and Byun, M.W. (2003). Irradiation effects on free radical scavenging and antioxidant activity of phytic acid. Journal of Food Science. 68(7): 2221-2224.

Alajaji, S.A. and El-Adawy, T.A. (2006). Nutritional composition of chickpea (Cicer arietinum L.) as affected by microwave cooking and other traditional cooking methods. Journal of Food Composition and Analisys. 19(8): 806-812.

Ali, M., Al-Saady, N.A., Waly, M.I., Bhatt, N., Al-Subhi, A.M. and Khan, A.J. (2014). Evaluation of indigeous Omani legumes for their nutritional quality, phytochemical composition and antioxidant properties. International Journal of Postharvest Technology and Innovation. 3: 333-346.

Al-Kaisey, M.T., Alwan, A.K.H., Mohammad, M.H. and Saeed, A.H. (2003). Effect of gamma irradiation on antinutritional factors in broad bean. Radiation Physics and Chemistry. 67(3-4): 493-496. 
Allende, A. and Artés, F. (2003). Combined ultraviolet-C and modified atmosphere packaging treatments for reducing microbial growth of fresh processed lettuce. LWT- Food Science Technology. 36: 779-786.

Allende, A. and Artés, F. (2005). Processing lines and alternative techniques to prolong the shelf-life of minimally fresh processed leafy vegetables. European Journal of Horticultural Science. 70: 231-245.

Allende, A., McEvoy, J., Tao, Y. and Luo, Y. (2009). Antimicrobial effect of acidified sodium chlorite, sodium chlorite, sodium hypochlorite, and citric acid on Escherichia coli $\mathrm{O} 157: \mathrm{H7}$ and natural microflora of fresh-cutcilantro. Food Control. 20: 230-234.

Alonso, R., Aguirre, A. and Marzo, F. (2000). Effects of extrusión and traditional processing methods on antinutrients and in vitro digestibility of protein and starch in faba and kidney beans. Food Chemistry. 68(2): 159-165.

Ansah, F.A., Amodio, M.L. and Colelli, G. (2018). Quality of fresh-cut products as affected by harvest and postharvest operations. Journal of the Science of Food and Agriculture. 98(10): 3614-3626.

Anurag, R.K., Manjunatha, M., Narayan, J.S. and Kumari, L. (2016). Storage quality of shelled green peas under modified atmosphere packaging at different storage conditions. Journal of Food Science and Technology. 53: 1640.

Aranda, P., Dostalova, J., Frias, J., Lopez-Jurado, M., Kozlowska, H., Pokorny, J., Urbano, G., Vidal-Valverde, C. and Zdyunczyk, Z. (2000). Nutrition. In CL Hedley, ed, Carbohydrates in Grain Legume Seeds: Improving Nutritional Quality and Agronomic Characteristics, CAB International, Wallingford, UK, pp 61-87.

Artés, F., Gómez, P., Aguayo, E., Escalona, V. and Artés-Hernández, F. (2009). Sustainable sanitation techniques for keeping quality and safety of fresh-cut plant commodities. Postharvest Biology and Technology. 51: 287-296.

Artés, F., Gómez, P.A. and Artés-Hernández F. (2007). Physical, physiological and microbial deterioration of minimally fresh processed fruits and vegetables. Food Science and Technology International. 13(3): 177-188.

Artés, F. and Artés-Hernández, F. (2012). Innovaciones en técnicas de procesado para facilitar el consumo de hortalizas y frutas. CTC. Revista de Agroalimentación e Industrias afines. 51: 9-15. 
Artés-Hernández, F., Aguayo, E., Gómez, P.A. and Artés, F. (2009a). Innovaciones tecnológicas para preservar la calidad de los productos vegetales mínimamente procesados o de la "cuarta gama”. Horticultura Internacional. 69: 52-57.

Artés-Hernández, F., Escalona, V.H., Robles, P.A., Martínez-Hernández, G.B. and Artés, F. (2009b). Effect of UV-C radiation on quality of minimally processed spinach leaves. Journal of Science of Food and Agriculture. 89: 414-421.

Artés-Hernández, F., Robles, P.A., Gómez, P.A., Tomás-Callejas, A. and Artés, F. (2010). Low UV-C illumination for keeping overall quality of fresh-cut watermelon. Postharvest Biology \& Technology. 55: 114-120.

Artés-Hernández, F., Gómez, P. and Artés, F. (2013). Unit processing operations used in minimally processed horticultural products: quality and safety preservation. In: Food Quality and Safety. Ed: G.P.P. Lima; F. Vianello. Edit: Springer Verlag. ISBN: 978-3-7091-1639-5. Pags: 35-52.

Artés-Hernández, F., Gómez, P., Aguayo, E., Tomás-Callejas A. and Artés F. (2014). Sustainable Processing of Fresh-Cut Fruit and Vegetables. In: Sustainable Food Processing. Ed: B.K. Tiwari, T. Norton, N.M. Holden. Edit: John Wiley \& Sons, Ltd. ISBN: 978-0-4706-7223-5. Chapter 10: 219-268.

Artés-Hernández, F., Formica-Oliveira, A.C., Artés, F., and Martínez-Hernández, G.B. (2017). Improved quality of a vitamin B12-fortified 'ready to blend' fresh-cut mix salad with chitosan. Food Science and Technology International. 23: 513-528.

Artés-Hernández, F., Martínez-Hernández, G.B., Aguayo, E., Gómez, P. and Artés, F. (2017). Fresh-cut fruit and vegetables: emerging eco-friendly techniques for preserving quality and safety. In: Postharvest Handling, Editorial: InTechOpen. Open access.

ASTM (1986). Physical requirements guidelines for sensory evaluation laboratories (Vol. 913, ASTM Special Technical Pub. 913). Philadelphia, USA: American Society for Testing Materials.

Baginsky, C., Peña-Neira, A., Cáceres, A., Hernández, T., Estrella, I., Morales, H. and Pertuzé, R. (2013). Phenolic compound composition in immature seeds of faba bean (Vicia faba L.) varieties cultivated in Chile. Journal of Food composition and Analysis. 31: 1-6.

Bahçeci, K.S., Serpen, A., Gökmen, V. and Acar, J. (2005). Study of lipoxygenase and peroxidase as indicator enzymes in green beans: change of enzyme activity, ascorbic 
acid and chlorophylls during frozen storage. Journal of Food Engineering. 66: 187192.

Balasundram, N., Sundram, K. and Samman, S. (2006). Phenolic compounds in plants and agri-industrial by-products: Antioxidant activity, occurrence, and potential uses. Food Chemistry. 99(1): 191-203.

Baldwin, E.A., Burns, J.K., Kazokas, W., Brecht, J.K., Hagenmaier, R.D., Bender, R.J. and Pesis, E. (1999). Effect of two edible coatings with different permeability characteristics on mango Mangifera indica L. ripening during storage. Postharvest Biology and Tecnhology. 17: 215-226.

Baljeet, S.Y., Roshanlal, Y. and Ritika, B.Y. (2016). Effect of cooking methods and extraction solvents on the antioxidant activity of summer squash (Cucurbita pepo) vegetable extracts. International Food Research Journal. 23(4): 1531-1540.

Barakat, H., Reim, V. and Rohn, S. (2015). Stability of saponins from chickpea, soy and faba beans in vegetarian, broccoli-based bars subjected to different cooking techniques. Food Research International. 76(1): 142-149.

Bari, M.L., Ukuku, D.O., Kawasaki, T., Inatsu, Y., Isshiki,K. and Kawamoto, S. (2005). Combined efficacy of nisin and pediocin with sodium lactate, citric acid, phytic acid, and potassium sorbate and EDTA in reducing the Listeria monocytogenes population of inoculated fresh-cut produce. Journal of Food Protection. 68: 13811387.

Barker, P.A. and Morris, D.J.M. (1968). Leucoanthocyanins in the Broad Bean barker. 170. 49. 79-86.

Barrett, D.M., Beaulieu, J.C., and Shewfelt, R. (2010). Color, flavor, texture, and nutritional quality of fresh-cut fruit and vegetables: desirable levels, instrumental and sensory measurement, and the effects of processing. Critical Reviews in Food Science and Nutrition. 50:369-389.

Barry T.N. and McNabb, W.C. (1999). The implications of condensed tannins on the nutritive value of temperate forages fed to ruminants. British Journal of Nutrition. 81: 263-272.

Beales, N. (2004) Adaptation of microorganisms to cold temperatures, weak acid preservatives, low $\mathrm{pH}$ and osmotic stress: A review. Comprehensive Reviews in Food Science and Food Safety. 3:1-20.

Beltrán, D., Selma, M.V., Tudela, J.A. and Gil, M.I. (2005). Effect of different sanitizers on microbial and sensory quality of fresh cut potato strips stored under 
modified atmosphere or vacuum packaging. Postharvest Biology and Technology. 37: 37-46.

Benlloch-Tinoco, M., Igual-Ramo, M., Rodrigo-Aliaga, MD., Martínez-Navarrete, N. (2013). Comparison of microwaves and conventional thermal treatment on enzymes activity and antioxidant capacity of kiwifruit puree. Innovative Food Science and Emerging Technologies. 19: 166-172.

Benzie, I.F.F. and Strain, J.J. (1999). Ferric reducing antioxidant power assay: direct measure of total antioxidant activity of biological fluids and modified version for simultaneous measurement of total antioxidant power and ascorbic acid concentration. Methods Enzymology. 299: 15-27.

Berhow, M.A., Cantrell, C.L., Duval, S.M., Dobbins, T.A., Maynes, J. and Vaughn, S.F. (2002). Analysis and quantitative determination of group B saponins in processed soybean products. Phytochemical Analysis. 13: 343-348.

Beuchat, L.R., Nail, B.V., Adler, B.B. and Clavero, M.R.S. (1998). Efficacy of spray application of chlorine in killing pathogenic bacteria on raw apples, tomatoes, and lettuce. Journal of Food Protection. 61: 1305-1311.

Bintsis, T., Litopoulou-Tzanetaki E. and Robinson, R.K. (2000). Existing and potential applications of ultraviolet light in the food industry-a critical review. Journal of the Science of Food and Agriculture. 80: 637-645.

Bognår, A., Bohling, H., Fort, H. (1990). Nutrient retention in chilled foods, in: Gormley, T.R. (Ed.), Chilled foods. The state of the art. Elsevier Applied Science, London, pp. 305-336.

Bouchenak, M. and Myriem, L.S. (2013). Nutritional quality of legumes and their role in cardiometabolic risk prevention: A Review. Journal of medicinal food. 16(3): 185-198.

Boukhenouf, S., Louaileche, H. and Perrin, D. (2016). Phytochemical content and in vitro antioxidant activity of faba bean (Vicia faba L.) as affected by maturity stage and cooking practice. International Food Research Journal. 23(3): 954-961.

Brand-Williams, W., Cuvelier, M.E. and Berset, C. (1995). Use of free radical method to evaluate antioxidant activity. Journal of Food Science and Technology. 28(1): 2530.

Caleb, O.J., Mahajan P.V., Al-Said F.A.J. and Opara U.L. (2013). Modified Atmosphere Packaging Technology of Fresh and Fresh-cut Produce and the Microbial Consequences-A Review. Food Bioprocess Technology. 6: 303-329. 
Campos-Vega, R. and Loarca-Piña, G. (2010). Minor components of pulses and their potential impact on human health. Food Research International, 43(2): 461-482.

Cantwell, M., and Saltveit, M. (2015). Tolerance of sugar snap peas to modified atmospheres with high concentrations of carbon dioxide. Acta Horticulturae. 1071:619-625.

Cartea, M.E., Francisco, M., Soengas, P. and Velasco, P. (2011). Phenolic Compounds i n Brassica. Vegetables. Molecules. 16(1): 251.

Carvalho, M., Lino-Neto, T., Rosa, E. and Carnide, V. (2017). Cowpea: a legume crop for a challenging environment. Journal of the Science of Food and Agriculture. 97(13): 4273-4284.

Castillejo, N., Martínez-Hernández, G.B., Gómez, P.A., Artés, F. and ArtésHernández, F. (2015). Red fresh vegetables smoothies with extended shelf life as an innovative source of health-promoting compounds. Journal of Food Science and Technology.

Castillejo, N., Martínez-Hernández, G.B., Gómez, P.A., Artés, F. and ArtésHernández, F. (2016). Red fresh vegetables smoothies with extended shelf-life as an innovative source of health-promoting compounds. Journal of Food and Science Technology. 53: 1475-1486.

Castillejo, N., Martínez-Hernández, G.B., Mónaco, K., Gómez, P.A., Aguayo, E., and Artés, F. (2017). Preservation of bioactive compounds of a green vegetable smoothie using short time-high temperature mild thermal treatment. Food Science and Technology International. 23(1): 46-60.

Castillejo, N., Martínez-Hernández, G.B., Lozano-Guerrero, A.J., Pedreño-Molina, J.L., Gómez, P.A., Aguayo, E., Artés, F. and Artés-Hernández, F. (2018). Microwave heating modelling of a green smoothie: Effects on glucoraphanin, sulforaphane and S-methyl cysteine sulfoxide changes during storage. Journal of the Science of Food and Agriculture. 98(5): 1863-1872.

Chaieb, N., González, L.J., Lopez-Mesas, M., Bouslama, M. and Valiente, M. (2011). Polyphenols content and antioxidant capacity of thirteen faba bean (Vicia faba L.) genotypes cultivated in Tunisia. Food Research International. 44: 970-977.

Cheok, C.Y., Salman, H.A.K. and Sulaiman, R. (2014). Extraction and quantification of saponins: A review. Food Research International. 59: 16-40. 
Chitravathi, K., Chauhan, O.P. and Raju, P.S. (2015). Influence of modified atmosphere packaging on shelf-life of green chillies (Capsicum annuum L.). Food Packaging and Shelf Life. 4: 1-9.

Chumyam, A., Whangchai, K., Jungklang, J., Faiyue, B. and Saengnil, K. (2013). Effects of heat treatments on antioxidant capacity and total phenolic content of four cultivars of purple skin eggplants. Science Asia. 39: 246-251.

Chung, K.T., Wong, T.Y., Wei, C.I., Huang, Y.W. and Lin, Y. (1998). Tannins and human health: A Review. Critical Reviews in Food Science and Nutrition. 38: 421464.

Cisneros-Zevallos, L. (2003). The use of controlled postharvest abiotic stresses as a tool for enhancing the nutraceutical content and adding-value of fresh fruits and vegetables. Journal of Food Science. 68: 1560-1565.

Collado, E., Venzke Klug, T., Martínez-Sánchez, A., Artés-Hernández, F., Aguayo, E., Artés, F., Fernández, J.A. and Gómez, P.A. (2017). Immature pea seeds. Effect of storage under modified atmosphere packaging and sanitation with acidified sodium chlorite. Journal of Science of Food Agriculture. 97(13): 4370-4378.

Contreras, C., Benlloch-Tinoco, M., Rodrigo, D. and Martínez-Navarrete, N. (2017). Impact of microwave processing on traditional, sensory, and other quality attributes. The Microwave Processing of Foods 2nd Edition. Editors: Marc Regier Kai Knoerzer Helmar Schubert. pp 65-99.

Costa, L., Vicente, A.R., Civello, P.M., Chaves, A.R., and Martínez, G.A. (2006). UVC treatment delays postharvest senescence in broccoli florets. Postharvest Biology and Technology. 39: 204-210.

Couée, C., Sulmon, G., Gouesbet, A. and Amrani, E. (2006). Involvement of soluble sugars in reactive oxygen species balance and responses to oxidative stress in plants. Journal of Experimental Botany. 57: 449-459.

Couto, A., Kortner, T.M., Penn, M., Østby, G., Bakke, A.M., Krogdahl, Å. (2015). Saponins and phytosterols in diets for European sea bass (Dicentrarchus labrax) juveniles: Effects on growth, intestinal morphology and physiology. Aquaculture Nutrition. 21(2): 180-193.

Crandall, P.G. (2012). Comparison of multiple chemical sanitizers for reducing Salmonella and Escherichia coli O157:H7 on spinach (Spinacia oleracea) leaves. Food Research International. 45(2): 1123-1128. 
Crépon. K., Marget, P., Peyronnet, C., Carrouée, B., Arese, P. and Duc, G. (2010). Nutritional value of faba bean (Vicia faba L.) seeds for feed and food. Field Crops Research. 115(3): 329-339.

Crozier, A., Jaganath, I.B. and Clifford, M.N. (2006). Phenols, polyphenols and tannins: An overview. In A. Crozier, M. Clifford, \& H. Ashihara (Eds.), Plant secondary metabolites: occurrence, structure and role in the human diet. Oxford, UK: Blackwell. pp. 1-24.

Dahl, W.J., Foster, L.M. and Tyler, R.T. (2012). Review of the health benefits of peas (Pisum Sativum L.). British Journal of Nutrition. 108: 3-10.

Davey, M.W., Montagu, M.V., Inzé, D., Sanmartin, M., Kanellis, A., Smirnoff, N., Benzie, I.J.J., Strain, J.J., Favell, D. and Fletcher, J. (2000). Plant L-ascorbic acid: Chemistry, function, metabolism, bioavailability and effects of processing. Journal of the Science of Food and Agriculture. 80: 825-860.

Delchier, N., Reich, M. and Renard, C.M.G.C. (2012). Impact of cooking methods on folates, ascorbic acid and lutein in green beans (Phaseoluos vulgaris) and spinach (Spinacea oloracea). Food Science and Technology. 49: 197-201.

Delzenne N.M. and Roberfroid M.R. (1994). Physiological effects of non-digestible oligosaccharides. Lebensmittel-Wissenschaft und Technologie. 27: 1-6.

Demir, M.K., and Elgün, A. (2013). Stabilization of whole wheat flour branny fractions with special emphasis on internal and external characteristic of whole wheat. Food Science and Technology Research. 19(2): 195-200.

Demir, M.K. and Elgün, A. (2014). Comparison of autoclave, microwave, IR and UV-C stabilization of whole wheat flour branny fractions upon the nutritional properties of whole wheat bread. Journal of Food Science and Technology. 51(1): 59-66.

Deng, G., Lin, X., Xu, X., Gao, L., Xie, J. and Li, H. (2013). Antioxidant capacities and total phenolic contents of 56 vegetables. Journal of Functional Foods. 5: 260-266.

Deng, Y., Padilla-Zakour, O., Zhao, Y. and Tao, S. (2015). Influences of high hydrostatic pressure, microwave heating, and boiling on chemical compositions, antinutritional factors, fatty acids, in vitro protein digestibility, and microstructure of buckwheat. Food and Bioprocess Technology. 8(11): 2235-2245.

Devasagayam, T.P.A., Tilak, J., Boloor, K.K., Sane, K.S., Ghaskadbi, S.S. and Lele, R. D. (2004). Free radicals and antioxidants in human health: current status and future prospects. Journal of the Association of Physicians of India. 52: 794-804. 
Devlieghere, F., Vermeulen, A. and Debevere, J. (2004). Chitosan: Antimicrobial activity, interactions with food components and applicability as a coating on fruit and vegetables. Food Microbiology. 21: 703-714.

Dias, M.I., Sousaa, M.J., Alves, R.C. and Ferreira, I. (2016). Exploring plant tissue culture to improve the production of phenolic compounds: A review. Industrial Crops and Products. 82: 9-22.

Dolinsky, M., Agostinho, C., Ribeiro, D., De Souza Rocha, G., Girão Barroso, S., Ferreira, D., Polinati, R., Ciarelli, G. and Fialho, E. (2016). Effect of different cooking methods on the polyphenol concentration and antioxidant capacity of selected vegetables. Journal of Culinary Science \& Technology. 14: 1-5.

Domínguez-Perles, R., Carnide, V., Marques, G., de Castro, I. and Rosa. E. (2015). Relevance, constraints and perspectives of cowpea crops in the Mediterranean Basin. Legume Perspectives. 10: 40-42.

Downie, B., Gurusinghe, S., Dahal, P., Thacker, R.R., Snyder, J.C. and Nonogaki, H. (2003). Expression of a galactinol synthase gene in tomato seeds is up-regulated before maturation desiccation and again after imbibitions whenever radicle protrusion is prevented. Plant Physiology. 131: 1347-1359.

Dragsted, L.O. (2003). Antioxidant actions of polyphenols in humans. International Journal for Vitamin and Nutrition Research. 73, 112-119.

Du, M., Cherian, G., Stitt, P.A. and Ahn, D.U. (2002). Effect of dietary sorghum cultivars on the storage stability of broiler breast and thigh meat. Poultry Science. 81: 1385-1391.

Duranti, M. and Gius, C. (1997). Legume seeds: protein content and nutritional value. Field Crops Research. 53: 31-45.

ED-European Parliament and Council Directive No 40/2008 (2008). On food additive other than colors and sweeteners.

https://www.fsai.ie/uploadedFiles/S.I_No_40_of_2008.pdf. Accessed 25.09.19.

El Gaouth, A., Arul, J., Ponnampalam, and R., Boulet, M. (1991). Chitosan coating effect on storability and quality of fresh strawberries. Journal of Food Science. 12: $1618-1632$.

ElSayed, A.I., Rafudeen, M.S. and Golldack, D. (2014). Physiological aspects of raffinose family oligosaccharides in plants: Protection against abiotic stress. Plant Biology. 16(1): 1-8. 
Elwan, M.W.M., Nasef, I.N., El-Seifi, S.K., Hassan, A.M. and Ibrahim, R.E. (2015). Storability, shelf-life and quality assurance of sugar snap peas (cv. super sugar snap) using modified atmosphere packaging. Postharvest Biology and Technology. 100: 205-211.

Erkan, M., Wang, C.Y. and Krizek, D.T. (2001). UV-C radiation reduces microbial populations and deterioration in Cucurbita pepo fruit tissue. Environmental and Experimental Botany. 45: 1-9.

Escalona, V.H., Hinojosa, A., Cha,r C., Villena, P., Bustamante, A. and Saenz, C. (2015). Use of alternative sanitizers on minimally processed watercress harvested in two different seasons. Journal of Food Processing and Preservation. 39:1287-1298.

Evans, W.J. and Martin, C.J. (1988). Heat of complex formation of Al (III) and Cd (II) with phytic acid. IX. J. Inorganic Biochemical. 34: 11-18.

Fabbri, A.D.T. and Crosby, G.A. (2016). A review of the impact of preparation and cooking on the nutritional quality of vegetables and legumes. International Journal of Gastronomy and Food Science. 3: 2-11.

Falguera, V., Quintero, J.P., Jimenez, A., Aldemar Muñoz, J. and Ibarza, A. (2011). Edible films and coatings: Structures, active functions and trends in their use. Trends in Food Science \& Technology. 22: 292-303.

FAOStat. (2017). Food and Agriculture Organization (FAO), World Production. Available at: http://faostat3.fao.org/browse/Q/QC/E (accessed 17 October 2018).

Flores, P., Hellín, P. and Fenoll, J. (2012). Determination of organic acids in fruit and vegetables by liquid chromatography with tandem-mass spectrometry. Food Chemistry. 132: 1049-1054.

Foley, D., Euper, M., Caporaso, F. and Prakash, A. (2004). Irradiation and chlorination effectively reduces Escherichia coli O157:H7 inoculated on cilantro (Coriandrum sativum) without negatively affecting quality. Journal of Food Protection. 67(10): 2092-2098.

Food and Drug Administration. Guide to Minimize Microbial Food Safety Hazards of $\begin{array}{llll}\text { Fresh-cut } & \text { Fruits } & \text { and }\end{array}$ http://www.fda.gov/downloads/Food/GuidanceRegulation/UCM169112.pdf.

Formica-Oliveira, A.C., Martínez-Hernández, G.B., Aguayo, E., Gómez, P.A., Artés, F. and Artés-Hernández, F. (2016). UVC and hyperoxia abiotic stresses to improve healthiness of carrots: Study of combined effects. Journal of Food Science and Technology. 53(9): 3465-3476. 
Formica-Oliveira, A.C., Martínez-Hernández, G.B., Díaz-López, V., Artés, F. and Artés-Hernández, F. (2017). Use of postharvest UV-B and UV-C radiation treatments to revalorize broccoli byproducts and edible florets. Innovative Food Science \& Emerging Technologies. 43: 77-83.

Francis, G., Kerem, Z., Makkar, H. P. and Becker, K. (2002). The biological action of saponins in animal systems: A review. British Journal of Nutrition. 88: 587-605.

Francis, G.A., Gallone, A., Nychas, G.J., Colelli, G., Amodio, M.L., Spano, G. and Sofos, J.N. (2012). Factors affecting quality and safety of fresh-cut produce. Critical Reviews in Food Science and Nutrition. 52: 595-610.

Frota, K.M.G., Mendonça, S., Saldiva, P., Cruz, R. and Areas, J. (2008). CholesterolLowering Properties of Whole Cowpea Seed and Its Protein Isolate in Hamsters. Journal of Food Science. 73(9): 235-240.

Gardner, D.W. and Shama, G. (2000). Modeling UV-induced inactivation of microorganisms on surfaces. Journal of Food Protection. 63: 63-70.

Gärtner, A. and Wese, U. (1986). Molecular and functional aspects of superoxide dismutases. In: Vögtle, F., Weber, E. (Eds.). Biomimetic and Bioorganic Chemistry II. Vol. 132. Springer-Verlag, Berlin, Germany. 1-61.

Gawłowska, M., Święcicki, W.K., Lahuta, L.B. and Kaczmarek Z. (2016). Raffinose family oligosaccharides in seeds of Pisum wild taxa, type lines for seed genes, domesticated and advanced breeding materials. Genetic Resources and Crop Evolution. 64: 569-578.

Gdala, J. and Buraczewska, L. (1997). Chemical composition and carbohydrate content of several varieties of faba bean and pea seeds. Journal of Animal and Feed Sciences. 6: 123-135.

Gibson D.M. and Ullah A.B.J. (1990). Phytases and their action on phytic acid. Inositol Metabolism in Plants. Morre, Biss, Loewus (Ed.), Wiley-Liss, NY, EEUU, 77-92.

Gil, M.I., Castañer, M., Ferreres, F., Artés, F. and Tomas-Barberan, F.A. (1998). Modified-atmosphere packaging of minimally processed 'Lollo Rosso' (Lactuca sativa). European Food Research and Technology. 206(5): 350-354.

Gil, M.I., Selma, M.V., López-Gálvez, F. and Allende, A. (2009). Fresh-cut product sanitation and wash water disinfection: Problems and solutions. International Journal of Food Microbiology. 134: 37-45. 
Gómez, P. and Artés, F. (2004). Ascorbic and citric acids to preserve quality of minimally processed green celery. In: Proceedings of IV Postharvest Iberian Symposium, Oeiras, Portugal, pp. 369-373.

Gómez, P.L., Alzamora, S.M., Castro, M.A. and Salvatori, D.M. (2010). Effect of ultraviolet-C light dose on quality of cut-apple: microorganism, color and compression behaviour. Journal of Food Engineering. 98: 60-70.

Gonçalves, A., Piebiep, G., Barros, A., Domínguez-Perles, R., Trindade, H., Rosa, E., Ferreira, L. and Rodrigues, M. (2016). Cowpea (Vigna unguiculata L. Walp) a renewed multipurpose crop for a more sustainable agri-food system. Nutritional advantages and constraints. Journal of Science and Food Agriculture. 96(9): 29412951.

Goyoaga, C. (2005). Estudio de factores no nutritivos en "Vicia faba I.": influencia de la germinación sobre su valor nutritivo. Tesis Doctoral. Facultad De Farmacia. Universidad Complutense De Madrid. 198 pp.

Goyoaga, C., Burbano, C., Cuadrado, C., Romero, C., Guillamón, E., Varela, A., Pedrosa, M.M. and Muzquiz, M. (2011). Content and distribution of protein, sugars and inositol phosphates during the germination and seedling growth of two cultivars of Vicia faba. Journal of Food Composition and Analysis. 24: 391-397.

Graça, A., Santo, D., Quintas, C.E. and Nunes, C. (2017). Growth of Escherichia coli, Salmonella enterica and Listeria spp., and their inactivation using ultraviolet energy and electrolyzed water, on Rocha fresh-cut pears. Food control. 77: 41-49.

Graf, E. and Eaton, J.W. (1990). Antioxidant functions of phytic acid. Free Radical Biology \& Medicine. 8(1): 61-69.

Graf, E., Empson, K.L. and Eaton, J.W. (1987). Phytic acid. A natural food antioxidant. Journal of Biological Chemistry. 262: 11647-11650.

Grizard, D. and Barthomeuf, C. (1999). Non-digestible oligosaccharides used as prebiotic agents: mode of production and beneficial effects on animal and human health. Reproduction Nutrition Development. 39: 563-588.

Güçlü-Üstündağ, Ö. and Mazza, G. (2007). Saponins: Properties, Applications and Processing. Critical reviews in food science and nutrition. 47: 231-58.

Gui-Fang. D., Xi, L., Xiang-Rong, X., Li-Li, G., Jie-Feng, X. and Hua-Bin, L. (2013). Antioxidant capacities and total phenolic contents of 56 vegetables. Journal Functional Food. 5: 260-266. 
Guilbert, S., Gontard, N. and Cuq, B. (1995). Technology and applications of edible protective films. Packaging Technology and Science. 8: 339-346.

Ha, T.J., Lee, B.W., Park, K.H., Jeong, S.H., Kima H.T., Ko J.M., Baek I.Y. and Lee J.H. (2014). Rapid characterisation and comparison of saponin profiles in the seeds of Korean Leguminous species using ultra performance liquid chromatography with photodiode array detector and electrospray ionisation/mass spectrometry (UPLCPDA-ESI/MS) analysis. Food Chemistry. 146: 270-277.

Han, H. and Baik, B.K. (2008). Antioxidant activity and phenolic content of lentils (Lens culinaris), chickpeas (Cicer arietinum L.), peas (Pisum sativum L.) and soybeans (Glycine max), and their quantitative changes during processing. International Journal of Food Science \& Technology. 43: 1971 - 1978.

Harris, L.J., Farber, J.N., Beuchat, L.R., Parish, M.E., Suslow, T.V., Garret, E.H. and Busta, F.F. (2003). Outbreaks associated with fresh produce: Incidence, growth, and survival of pathogens in fresh and fresh-cut produce. Comprehensive Reviews in Food Science and Food Safety. 2: 78-141.

Hassanpour, S., Maheri-Sis, N., Eshratkhah, B. and Baghbani Mehmandar, F. (2011). Plants and secondary metabolites (Tannins): A Review. International Journal of Forest, Soil and Erosion. 1: 47-53.

Hefnawy, H. (2011). Effect of processing methods on nutritional composition and antinutritional factors in lentils (Lens culinaris). Annals Agriculture Science. 56(2): 5761.

Heng, L., Vincken, J.P., Hoppe, K., Koningsveld, G.A., Decroos, K., Gruppen, H., Boekel, M.A.J.S. and Voragen, A.G.J. (2006). Stability of pea DDMP saponin and the mechanism of its decomposition. Food Chemistry. 99: 326-334.

Heredia, J.B. and Cisneros-Zevallos, L. (2009). The effects of exogenous ethylene and methyl jasmonate on the accumulation of phenolic antioxidants in selected whole and wounded fresh produce. Food Chemistry. 115 (4): 1500-1508.

Hithamani, G., and Srinivasan, K. (2014). Bioaccessibility of polyphenols from wheat (Triticum aestivum), sorghum (Sorghum bicolor), green gram (Vigna radiata), and chickpea (Cicer arietinum) as influenced by domestic food processing. Journal of Agriculture and Food Chemistry. 62(46): 11170-9.

Hoeck, J.A., Fehr, W.R., Murphy, P.A. and Welke, G.A. (2000). Influence of genotype and environment on isoflavone contents of soybean. Crop Science. 40: 48-51. 
Hrudey, S.E. (2009). Chlorination disinfection by-products, public health risk tradeoffs and me. Water Research. 43: 2057-2092.

Hughes, P.A. and Sandsted, R.F. (1975). Effect of temperature, relative humidity and light on the color of 'California Light Red Kidney' bean seeds during storage. Hortscience. 10: 421-423.

Hurst, W.C. (2002). Safety aspects of fresh-cut fruits and vegetables. Fresh-Cut Fruits and Vegetables. Science, Technology and Market. 45-90.

Inatsu, Y., Maeda, Y., Bari, M.L., Kawasaki, S.W. and Kawamoto, S. (2005). Prewashing with acidified sodium chlorite reduces pathogenic bacteria in lightly fermented Chinese cabbage. Journal of Food Protect. 68: 999-1004.

ISO (2012). Sensory analysis -- General guidelines for the selection, training and monitoring of selected assessors and expert sensory assessors. In I. O. f. S. (ISO) (Ed.), 8586:2012. Geneva.

Jain, A., Singh, A., Singh, S., Sarma, B.K. and Singh, H.B. (2015). Biocontrol agentsmediated suppression of oxalic acid induced cell death during Sclerotinia sclerotiorum-pea interaction. Journl of Basic Microbiology. 55(5): 601-606.

Kader, A.A. (2002). Modified atmospheres during transport and storage. Kader. A. A. (Ed.). Postharvest technology of horticultural crops. Publication 3311. 3rd edition. Edit. University of California, Agriculture and Natural Resources, Davis USA. 135145 .

Kadlec, P., Kaasová, J., Bubník, Z. and Pour, V. (2000b). Effect of germination and microwave treatment on chemical composition of pea. Microwave Chemistry. 241243.

Kadlec, P., Rubecová, A., Réblová, Z., Starhová, H. and Bubník, Z. (2000a). Influence of germination on the carbohydrate composition of pea. Czech Journal of Food Sciences. 18: 9-13.

Kala, B. and Mohan, V. (2012). Effect of microwave treatment on the antinutritional factors of two accessions of velvet bean, Mucuna pruriens (L.) DC. var. utilis (Wall. ex Wight) Bak. ex Burck. International Food Research Journal 19(3): 961-969.

Kalpanadevi, V. and Mohan, V.R. (2013). Effect of processing on antinutrients and in vitro protein digestibility of the underutilized legume, Vigna unguiculata (L.) Walp subsp. Unguiculata. LWT - Food Sci Technol. 51(2): 455-461. 
Kannan, U., Sharma, R., Gangola, M.P. and Chibbar, R. N. (2018). Improving Grain Quality in Pulses: Strategies to Reduce Raffinose Family Oligosaccharides in Seeds. Ekin Journal of Crop Breeding and Genetics. 4: 70-88.

Karapanos, I., Papandreou, A., Skouloudi, M., Makrogianni, D., Fernández, J.A., Rosa, E., Ntatsi, G., Bebeli, P.J. and Savvas, D. (2017). Cowpea fresh pods - a new legume for the market: assessment of their quality and dietary characteristics of 37 cowpea accessions grown in southern Europe. Journal of Science and Food Agriculture. 97(13): 4343-4352.

Kemp, G., Aldrich, M.L. and Waldroup, A.L. (2000). Acidified Sodium Chlorite Antimicrobial Treatment of Broiler Carcasses. Journal of food protection. 63: 108792.

Kerch, G. (2015). Chitosan films and coatings prevent losses of fresh fruit nutritional quality: A review. Trends in Food Science \& Technology. 46: 159-166.

Kester, J.J. and Fennema, O.R. (1986). Edible films and coatings: A review. Food Technology. 40: 47-59.

Khademi, O., Zamani, Z., Poor Ahmadi, E. and Kalantari, S. (2012). Effect of UV-C radiation on postharvest physiology of persimmon fruit (Diospyros kaki Thunb.) cv. 'Karaj' during storage at cold temperature. International Food Research Journal. 20(1): 247-253.

Khalil, A.H. and Mansour, E.H. (1995). The effect of cooking, autoclaving and germination on the nutritional quality of faba beans. Food Chemistry. 54(2): 177182.

Khalil, A.H. and El-Adawy, T.A. (1994). Isolation, identification and toxicity of saponin from different legumes. Food Chemistry. 50(2): 197-201.

Khan, M., Cakmak, H., Tavman, S., Schutyser, M. and Schroën, K. (2014). Antibrowning and barrier properties of edible coatings prepared with electrospraying, Innov. Innovative Food Science and Emerging Technologies. 25: 9-13.

Khattab, R.Y. and Arntfield, S.D. (2009). Nutritional quality of legume seeds as affected by some physical treatments 2. Antinutritional factors. LWT - Food Science Technology. 42(6): 1113-1118.

Kim, M.S., Cho, S.M., Kang, E.Y., Im, Y.J., Hwangbo, H. and Kim, Y.C. (2008). Galactinol is a signaling component of the induced systemic resistance caused by Pseudomonas chlororaphis O6 root colonization. Molecular Plant-Microbe Interactions Journal. 21: 1643-1653. 
Kinyuru, J.N., Kahenya, K.P., Muchui, M. and Mungai, H. (2011). Influence of Postharvest Handling on the Quality of Snap Bean (Phaseolus vulgaris L.). Journal of Agriculture and Food Technology. 1(5): 43-46.

Klaiber, R.G., Baur, S., Wolf, G., Hammes, W. P. and Carle, R. (2005). Quality of minimally processed carrots as affected by warm water washing and chlorination. Innovative Food Science and Emerging Technologies. 6: 351-362.

Klug, T., Martínez-Hernández, G., Collado, E., Artés, F. and Artés-Hernández, F. (2018a). Effect of Microwave and High-Pressure Processing on Quality of an Innovative Broccoli Hummus. Food and Bioprocess Technology. 1-14.

Klug, T.V., Collado, E., Martínez-Sánchez, A., Gómez, P.A., Aguayo, E., Otón, M., Artés, P. and Artés-Hernández, F. (2018b). Innovative quality improvement by continuous microwave processing of a faba beans pesto sauce. Food Bioprocess Technology. 11(3): 561-571.

Knuckles, B.E., Kuzmicky, D.D. and Betschart, A.A. (1982). HPLC analysis of phytic acid in selected foods and biological samples. Journal of Food Science. 49: 12671268.

Kwon, S.J., Kim, D.G., Kim, J.M., Kang, K.Y., Lee, M.K., Hong, M.J., Kim, J.B., Eom, S.H., Kang, S.Y., Ha, B.K. and Ryu J. (2018). Phytochemical Compounds and Antioxidant Activity in the Grain of Selected Faba Bean (Vicia faba) Genotypes. Plant Breeding and Biotechnology. 6(1): 65-73.

Lado, B. and Yousef, A. (2002). Alternative food-preservation technologies: efficacy and mechanisms. Microbes Infection. 4: 433-440.

Lásztity, R., Hidvégi, M. and Bata, Á. (1998). Saponins in food. Food Reviews International. 14(4): 371-390.

Le Tien, C., Vachon, C., Mateescu, M. A. and Lacroix, M. (2001). Milk protein coatings prevent oxidative browning of apples and potatoes. Journal of Food Science. 66: 512-516.

Lee, S.K. and Kader. A.A. (2000). Preharvest and postharvest factors influencing vitamin $\mathrm{C}$ content of horticultural crops. Postharvest Biology and Technology. 20 (3): 207-220.

Leguminosae, V. (2012). Faba Bean. Genetics, Genomics and Breeding of Cool Season Grain Legumes, 27(Latokartanonkaari 5), 50-97. 
Leistner, L, and Gould, G. (2002). Hurdle technologies: combination treatments for food stability, safety and quality. Kluwer Academic/Plenum Publishers, New York, USA. 24-25.

López-Gálvez, F., Allende, A., Truchado, P., Martínez-Sánchez, A., Tudela, J.A., Selma, M.V. and Gil, M.I. (2010). Suitability of aqueous chlorine dioxide versus sodium hypochlorite as an effective sanitizer for preserving quality of fresh-cut lettuce while avoiding by-product formation. Postharvest Biology and Technology. 55(1): 53-60.

López-Gálvez, F., Allende, A., Truchado, P., Martínez-Sánchez, A., Tudela, J.A., Selma, M.V. and Gil, M.I. (2010). Suitability of aqueous chlorine dioxide versus sodium hypochlorite as an effective sanitizer for preserving quality of fresh-cut lettuce while avoiding by-product formation. Postharvest Biology and Technology. 55: 53-60.

Luo, Y.W. and Xie, W.H. (2013). Effect of different processing methods on certain antinutritional factors and protein digestibility in green and white faba bean (Vicia faba L.). CyTA - Journal of Food. 11(1): 43-49.

Maetens, E., Hettiarachchy, N., Dewettinck, K., Horax, R. and Moens, K. (2018). Reductions of anti-nutritional factors of germinated soybeans by ultraviolet and infrared treatments for snack chips preparation. LWT - Food Science and Technology. 90: 513-518.

MAGRAMA. (2019). https://www.mapa.gob.es/es/agricultura/temas/produccionesagricolas/anexo_proteaginosas_oct2019_tcm30-521009.pdf

Manzocco, L., Quarta, B. and Dri, A. (2009). Polyphenoloxidase inactivation by light exposure in model systems and apple derivatives. Innovative Food Science \& Emerging Technologies. 10(4): 506-511.

Manzocco, L., Da Pieve, S. and Maifreni, M. (2011). Impact of UV-C light on safety and quality of fresh-cut melon. Innovative Food Science and Emerging Technologies. 12: 13-17.

Martínez-Damián, M.T., Cruz-Álvarez, O., Beryl Colinas-León M.T., Rodríguez-Pérez, J.E. and Ramírez-Ramírez, S.E. (2013). Actividad enzimática y capacidad antioxidante en menta (Mentha piperita L.) almacenada bajo refrigeración. Agronomía mesoamericana. 24:57-69. 
Martínez-Hernández, G.B., Gómez, P.A., Pradas, I., Artés, F. and Artés-Hernández, F. (2011). Moderate UV-C pretreatment as a quality enhancement tool in fresh-cut Bimi® broccoli. Postharvest Biology and Technology. 62: 327-337.

Martínez-Hernández, G.B., Artés-Hernández, F., Colares-Souza, F., Gómez, P.A., García-Gómez, P. and Artés, F. (2013a). Innovative Cooking Techniques for Improving the Overall Quality of a Kailan-Hybrid Broccoli. Food and Bioprocess Technology. 6(8): 2135-2149.

Martínez-Hernández, G.B., Artés-Hernández, F., Gómez, P.A. and Artés, F. (2013b). Comparative behaviour between kailan-hybrid and conventional fresh-cut broccoli throughout shelf-life. Food Science and Technology. 50(1): 298-305.

Martínez-Hernández, G.B., Artés-Hernández, F., Gómez, P.A. and Artés, F. (2013c). Induced changes in bioactive compounds of kailan-hybrid broccoli after innovative processing and storage. Journal of Functional Foods. 5(1): 133-143.

Martínez-Hernández, G.B., Artés-Hernández, F., Gómez, P.A., Formica, A.C. and Artés, F. (2013d). Combination of electrolysed water, UV-C and superatmospheric O2 packaging for improving fresh-cut broccoli quality. Postharvest Biology and Technology. 76: 125-134.

Martínez-Hernández, G., Amodio, M., and Colelli, G. (2015). Potential use of microwave treatment on fresh-cut carrots: Physical, chemical and microbiological aspects. Journal of the science of food and agriculture. 96: 2063-2072.

Martínez-Sánchez, A., Allende, A., Bennett, R.N., Ferreres, F. and Gil, M.I. (2006). Microbial, nutritional and sensory quality of rocket leaves as affected by different sanitizers. Postharvest Biology and Technology. 42: 86-97.

Martínez-Sánchez, A., Allende, A., Cortés-Galera, Y. and Gil, M.I. (2008). Respiration rate response of four baby leaf Brassica species to cutting at harvest and fresh-cut washing. Postharvest Biology and Technology. 47: 382-388.

Martínez-Valverde, I., Periago, M.J., Gordon, Provan, G. and Chesson, A. (2000). Phenolic compounds, lycopene and antioxidant activity in commercial varieties of tomato (Lycopersicum esculentum). Journal of the Science and Food Agriculture. 82: 323-330.

Martos-Fuentes, M., Fernandez, J., Ochoa, J., Carvalho, M., Carnide, V., Rosa, E., Pereira, G., Barcelos, C. J., Bebeli, P. and Egea-Gilabert, C. (2017). Genotype by environment interactions in cowpea (Vigna unguiculata L. Walp.) grown in the Iberian Peninsula. Crop Pasture Science. 68: 924-931. 
Masrizal, M.A., Giraud, D.W. and Driskell, J.A. (1997). Retention of vitamin C, iron, and carotene in vegetables prepared using different cooking methods. Journal of Food Quality. 20: 403-418.

McHugh, T.H. and Senesi, E. (2000). Apple wraps: A novel method to improve the quality and extend the shelf life of fresh-cut apples. Journal of Food Science. 65: $480-485$.

McKie, V.A. and McCleary, B.V. (2016). A novel and rapid colorimetric method for measuring total phosphorus and phytic acid in foods and animal feeds. Journal of AOAC International. 99(3): 738-743.

Miller, L.A., Gordon, J. and Davis, E.A. (1991). Dielectric and thermal transition properties of chemically modified starches during heating. Journal of Cereal Chemistry. 68: 441-448.

Miller, N. and Rice-Evans, C.A. (1997). The relative contributions of ascorbic acid and phenolic antioxidants to the total antioxidant activity of orange and apple fruit juices and blackcurrant drink. Food Chemistry. 60: 331-337.

Miller, F.A., Ramos, B., Gil, M.M., Brandão, T.R.S., Teixeira, P. and Silva, C.L.M. (2009). Influence of $\mathrm{pH}$, type of acid and recovery media on the thermal inactivation of Listeria innocua. International Journal of Food Microbiology. 133(1-2): 121128.

Moldao-Martins, M., Beirao-da-Costa, S.M. and Beirao-da-Costa, M.L. (2003). The effects of edible coatings on postharvest quality of the "Bravo de Esmolfe" apple. European Food Research and Technology. 217: 325-328.

Multari, S., Stewart, D. and Russell, W.R. (2015). Potential of fava bean as future protein supply to partially replace meat intake in the human diet. Comprehensive Reviews in Food Science and Food Safety. 14: 511-522.

Munyaka, A.W., Makule, E.E., Oey, I., Van Loey, A. and Hendrickx, M. (2010). Thermal stability of L-ascorbic acid and ascorbic acid oxidase in broccoli (Brassica oleracea var. italica). Journal of Food Science. 75: 336-340.

Nakajima, S., Lan, L., Kanno, S., Takao, M., Yamamoto, K., Eker, A.P. and Yasui, A. (2004). UV light-induced DNA damage and tolerance for the survival of nucleotide excision repairdeficient human cells. Journal of Biological Chemistry. 279(45): 46674-46677. 
Nassourou, M.A., Njintang, Y.N., Noubissié, T.J.B., Nguimbou, R.M. and Bell, J.M. (2016). Genetics of seed flavonoid content and antioxidant activity in cowpea (Vigna unguiculata L. Walp.). Crop Journal. 4(5): 391-397.

Nath, A., Bagchi, B., Misra, L.K. and Deka, B.C. (2011). Changes in post-harvest phytochemical qualities of broccoli florets during ambient and refrigerated storage. Food Chemistry. 127:1510-1514.

Navarro-Rico J. (2015). Optimización del procesado mínimo y biodisponibilidad de compuestos bioactivos de brócoli bimi y convencional (Tesis Doctoral). Universidad Politécnica de Cartagena, España.

Navarro-Rico, J., Martínez-Hernández, G.B., Artés, F., Artés-Hernández, F. and Gómez, P.A. (2015). Effect of edible coatings and electrolyzed water sanitation on fresh-cut 'bimi' broccoli quality. Acta Hort. (ISHS). 1071:463-469.

Neal, J.A., Marquez-Gonzalez, M., Cabrera-Diaz, E., Lucia, L.M., O'Bryan, C.A. and Crandall, P.G. (2012). Comparison of multiple chemical sanitizers for reducing Salmonella and Escherichia coli O157: H7 on spinach (Spinacia oleracea) leaves. Food Research International. 45(2): 1123-1128.

Negueruela, A. I. (2012). Chapter 9: Is the color measured in food the color that we see? In J. L. Caivano, \& M. P. Buera (Eds.), Color in food: Technological and psychophysical aspects (pp. 171e180). Boca Raton, FL: CRC Press.

Nelson, D.L., Cuchillo, Foix, C.M., Lehninger, A.L. and Cox, M.M. (2005). Lehninger: Principios de Bioquímica (4a. ed.). Barcelona: Omega.

Nieuwenhuijsen, M.J., Toledano, M.B. and Elliot, P. (2000). Uptake of chlorination disinfection by-products; a review and a discussion of its implications for exposure assessment in epidemiological studies. Journal of Exposure Analysis and Environmental Epidemiology. 10: 586-599.

Nikmaram, N., Leong, S.Y., Koubaa, M., Zhu, Z., Barba, F.J., Greiner, R., Oey, I. and Roohinejad, S. (2017). Effect of extrusion on the anti-nutritional factors of food products: An overview. Food Control. 79: 62-73.

Nithya, K.S., Ramachandramurty, B. and Krishnamoorthy, V.V. (2007). Effect of processing methods on nutritional and anti-nutritional qualities of hybrid (COHCU8) and traditional (CO7) Pearl Millet varieties of India. Journal of Biological Sciences. 7(4): 643-647. 
Nordstorm, C.L. and Sistrunk, W.A. (1977). Effect of type of bean, soak time, canning media and storage time on quality attributes and nutrient content of canned dry beans. Journal of Food Science. 42: 795-798.

Noubissie Tchiagam, J.B., Emmanuel, Y., Nicolas, N., Bell, J.M., and Nassourou, A. (2011). Generation Means Analysis of Seed Sucrose Content in Cowpea (Vigna unguiculata L. Walp.). Asian Journal of Agriculture Science. 3: 475-480.

Nozzolillo, C. and De Bezada, M. (1984). Browning of lentil seeds, concomitant loss of viability, and the possible role of soluble tannins in both phenomena. Canadian. Journal of Plant Science. 64: 815-824.

Ntatsi, G., Egea-Cortines, M., Karapanos, I., Barros, A., Weiss, J., Balliu, A., Augusto dos Santos Rosa, E. and Savvas, D. (2018). The quality of leguminous vegetables as influenced by preharvest factors. Scientia Horticulturae. 232: 191-205.

O`Dell, B.L. and de Boland, A. (1976). Complexation of phytate with proteins and cations in corn and oilseed meals. Journal of Agricultural and Food Chemistry. 24: 804-808.

Ofuya, Z.M. and Akhidue, V. (2005). The Role of Pulses in Human Nutrition: A Review. Journal of Applied Sciences and Environmental Management. 9(3): 99 104.

Ogunlade, I., Ogunleye, R.T. and Osasona, I. (2014). Chemical composition, antioxidant capacity and total phenolic content of the flours obtained from cowpea (Vigna unguiculata) varieties commonly consumed in Nigeria. British Journal of Applied Science \& Technology. 4(12): 1729-1734.

Okada, M. and Ye, K. (2009). Nuclear phosphoinositide signaling regulates messenger RNA export. RNA Biology. 6: 12-16.

Olaimat, A.N. and Holley, R.A. (2012). Factors influencing the microbial safety of fresh produce: a review. Food Microbiology. 32: 11-19.

Oliveira, A.P., Araújo, J.S., Alves, E.U., Noronha, M.A.S., Cassimiro, C.F., and Mendonça, F.G. (2001). Yield of cowpea-beans cultivated with bovine manure and mineral fertilization. Horticultura Brasileira. 19: 81-84.

Ölmez, H. and Kretzschmar, U. (2009). Potencial alternative disinfection methods for organic fresh-cut industry for minimizing water consumption and environmental impact. Lebensmittel-Wissenschaft und Technologie. 42: 686-693.

Onigbinde, A. and Akinyele, I.O. (1983). Oligosaccharide content of 20 varieties of cowpeas in Nigeria. Journal of Food Science. 48: 1250-1254. 
Otón, M., Artés, F. and Artés-Hernández, F. (2014). Efecto de agentes desinfectantes alternativos al hipoclorito sódico en la calidad de habas mínimamente procesadas en fresco. En: Actas del III Workshop en Investigación Agroalimentaria. Editores: F. Artés-Hernández, M. Egea-Cortines, A. Palop-Gómez, S. Bañón-Arias, P. Bielza. Editorial: Universidad Politécnica de Cartagena. ISBN: 978-84-697-1358-7. Cartagena, Murcia, España. 58-61.

Otón, M., Artés, F. and Artés-Hernández, F. (2016). Optimization of chlorine sanitation to preserve quality of minimally processed Vicia faba seeds. En: Proceedings of the 4th Workshop on Agri-Food Research. Editors: F. Artés-Hernández, M. EgeaCortines, J. Fernández-Hernández, A. Baile, J. Calatrava. Editorial: Universidad Politécnica de Cartagena. ISBN: 978-84-608-5399-2. Cartagena, Murcia, España. Mayo 2015. 51-54.

Otón, M., Artés, F. and Artés-Hernández, F. (2017). Antibrowning washing agents effect to preserve quality of minimally processed Vicia faba seeds. En: Proceedings of the 5th Workshop on Agri-Food Research. Editors: F. Artés-Hernández, J.A. Fernández-Hernández, J. Calatrava, E. Aguayo; JJ Alarcón, JE Cos. Editorial: Universidad Politécnica de Cartagena. ISBN: 978-84-16325-29-0. Cartagena, Murcia, España. Mayo 2016. 223 pp. 40-43.

Pallauf J. and Rimbach G. (1997). Nutritional significance of phytic acid and phytase. Archives of Animal Nutrition. 50: 301-319.

Pariasca, J.A.T, Miyazaki, T., Hisaka, H., Nakagawa, H. and Sato, T. (2001). Effect of modified atmosphere packaging (MAP) and controlled atmosphere (CA) storage on the quality of snow pea pods (Pisum sativum L. var. saccharatum). Postharvest Biology and Technology. 21:231-223.

Park, D. and Maga, J.A. (1999). Dry bean (Phaseolus vulgaris) color stability as influenced by time and moisture content. Journal of Food Processing and Preservation. 23(6): 515-522.

Parra-Galant, J. (2009). El haba muchamiel. Horticultura Internacional 70: 32-33.

Peleg, H., Naim, M., Rouseff, R.L. and Zehavi, U. (1991). Distribution of bound and free phenolic acids in oranges (Citrus sinensis) and Grapefruits (Citrus paradisi). Journal of the Science of Food and Agriculture. 57(3): 417-426.

Peng, W., Ji-Chun T., Walker, C.E. and Feng-Cheng, W. (2009). Determination of phytic acid in cereals - A brief review. International Journal of Food Science and Technology. 44: $1671-1676$. 
Peterbauer, T. and Richter, A. (2001). Biochemistry and physiology of raffinose family oligosaccharides and galactosylcyclitols in seeds. Seed Science Research. 11: 185197.

Pinto, E.P., Perin, E.C., Schott, I.B., da Silva Rodrigues, R., Lucchetta, L., Manfroi, V. and Rombaldi, C.V. (2016). The effect of postharvest application of UV-C radiation on the phenolic compounds of conventional and organic grapes (Vitis labrusca cv. 'Concord'). Postharvest Biology and Technology. 120: 84-91.

Pinto, P.M.Z. and Morais, A.M.M.B. (Eds.). (2000). Boas práticas para a conservação de produtos horto frutícolas. 1 st. Ed. AESBUC: Associação para a Escola Superior de Biotecnologia de Universidade Católica: Porto, p. 39.

Price, M.L., Van Scoyoc, S., and Butler, L.G. (1978). A critical evaluation of the vanillin reaction as an assay for tannin in sorghum grain. Journal of Agricultural and Food Chemistry. 26(5): 1214-1218.

Price, K., Curl, C., and Fenwick, G. (1986). The saponin content and sapogenol composition of the seed of 13 varieties of legume. Journal of the Science of Food and Agriculture. 37: 1185-1191.

Price, K.R., Johnson, I.T. and Fenwick, G.R. (1987). The chemistry and biological significance of saponins in foods and feeding stuff. CRC Critical Reviews in Food Science and Nutrition. 26: 27-131.

Price, M.L., Socoyoc, S.V. and Butler, L. (1978). A certical evaluation of the vanillin reaction as an assay for tannin on sorgum graim. Journal of Agricultural and Food Chemistry. 26: 1214-1218.

Raes, K., Knockaert, D., Struijs, K. and Van Camp, J. (2014). Role of processing on bioaccessibility of minerals: Influence of localization of minerals and antinutritional factors in the plant. Trends in Food Science and Technology. 37(1): 3241.

Rao, P.U. and Belavady, B. (1978). Oligosaccharides in pulses: Varietal differences and effects of cooking and germination. Journal of Agricultural and Food Chemistry. 26(2): 316-319.

Raybaudi-Massilia, R., Mosqueda-Melgar, J., Soliva-Fortuny, R. and Martín-Belloso, O. (2016). Combinational edible antimicrobial films and coatings, in: BarrosVelázquez, J. (Ed.), Antimicrobial food packaging. Elsevier, Amsterdam, pp. 633646. 
Regulation 1441/2007 (2007) https://www.boe.es/diario_boe/xml.php?id=DOUE-L2007-82244.

Reim, V. and Rohn, R. (2015). Characterization of saponins in peas (Pisum sativum L.) by HPTLC couple to mass spectrometry and a hemolysis assay. Food Research International. 76: 3-10.

Revilla, I. (2015). Impact of thermal processing on faba bean (Vicia faba) composition, in: Preedy, V. (Ed.), Processing and impact on active components in food. Elsevier, Amsterdam, pp. 337-343.

Rico, D., Martín-Diana, A.B., Barat, J.M. and Barry-Ryana, C. (2007). Extending and measuring the quality of fresh-cut fruit and vegetables: a review. Trends in Food Science \& Technology. 18: 373-386.

Riedl, K.M., Carando, S., Alessio, H.M., McCarthy, M. and Hagerman, A.E. (2002). Antioxidant activity of tannins and tannin-protein complexes: Assessment in vitro and in vivo. In: Morello MJ, Shahidi F and Ho C-T (eds) Free Radicals in Food. ACS Symposium Series, Washington, DC: American Chemical Society, pp.188200.

Robles, P., de Campos, A., Artés-Hernández, F., Gómez, P., Calderón, A., Ferrer, M. and Artés, F. (2007). Combined effect of UV-C radiation and controlled atmosphere storage to preserve tomato quality. V Congreso Iberoamericano de Tecnología Postcosecha y Agroexportaciones. Cartagena, Spain.

Rodríguez-Hidalgo, S., Artés-Hernández, F., Gómez, P.A., Fernández, J. and Artés, F. (2010). Quality of fresh-cut baby spinach grown under floating trays system as affected by $\mathrm{N}$ fertilization and innovative package treatments. Journal of Science and Food Agriculture. 90: 1089-1097.

Rodríguez-Verástegui, L.L., Martínez-Hernández, G.B., Castillejo, N., Gómez, P.A., Artés, F. and Artés-Hernández, F. (2016). Bioactive compounds and enzymatic activity of red vegetable smoothies during storage. Food and Bioprocess Technology. 9(1): 137-146.

Rosen, J. and Kader, A., (1989). Postharvest physiology and quality maintenance of sliced pear and strawberry fruits. Journal of Food Science. 54: 656-659.

Rubio, L.A., Pedrosa, M.M., Pérez, A., Cuadrado, C., Burbano, C. and Muzquiz, M. (2005). Ileal digestibility of defatted soybean, lupin and chickpea seed meals in cannulated iberian pigs: II. Fatty acids and carbohydrates. Journal of the Science of Food and Agriculture. 85: 1322-1328. 
Ruiz-Cruz, S., Islas-Osuma, M.A., Sotelo-Mundo, R.R., Vázquez-Ortiz, F. and González-Aguilar, G.A. (2007). Sanitation procedure affects biochemical and nutritional changes of shredded carrots. Journal of Food Science. 72:146-152.

Ruiz-Cruz, S., Luo, Y., Gonzalez, R.J., Tao, Y. and González, G.A. (2006). Acidified sodium chlorite as an alternative to chlorine to control microbial growth on shredded carrots while maintaining quality. Journal of the Science of Food and Agriculture. 86:1887-1893.

Sahidi, F. and Ambigaipalan, P. (2015). Phenolics and polyphenolics in foods, beverages and spices: Antioxidant activity and health effects - A review. Journal of Functional Foods. 18: 820-897.

Saini, P., Singh, P., Dubey, S. and Srivastava, A. (2016). Effect of different processing methods on polyphenolic content and antioxidant activity of broad beans (Vicia faba). International journal of Critical Research and Review. 8: 6-11.

Saito M., Hosoyama H., Ariga T., Kataoka S. and Yamaji N. (1998). Antiulcer activity of grape seed extract and procyanidins. Journal of Agricultural and Food Chemistry. 46: $1460-1464$.

Sakanaka S., Sato T., Kim M. and Yamamoto T. (1990). Inhibitory effects of green tea polyphenols on glucan synthesis and cellular adherence of cariogenic streptococci. Agricultural and Biological Chemistry. 54(11): 2925-2929.

Sánchez-Mata, M.C., Camara, M. and Diez-Marques, C. (2003). Extending shelf-life and nutritive value of green beans (Phaseolus vulgaris L.), by controlled atmosphere storage: macronutrients. Food Chemistry. 80: 309-315.

Santos-Buelga C., and Scalbert A. (2000). Proanthocyanidins and tannin-like compounds-nature, occurrence, dietary intake and effects on nutrition and health. Journal of the Science of Food and Agriculture. 80: 1094-1117.

Sapers, G. (1993). Scientific status summary browning of foods: control by sulphites, antioxidants and other means. Food Technology. 47: 75-84.

Savage, G. P, and Deo, S. (1989). The Nutritional Value of Peas (Pisum sativum). A Literature Review. Nutrition Abstracts and Reviews. 59 (2): 66-89.

Scalbert, A., Manach, A., Morand, C., Remesy, C. and Jiménez, L. (2005). Dietary polyphenols and the prevention of diseases. Critical Reviews in Food Science and Nutrition. 45: 287-306. 
Selcuk, N. and Erkan. M. (2014). Changes in antioxidant activity and postharvest quality of sweet pomegranates cv. Hicrannar under modified atmosphere packaging. Postharvest Biology and Technology. 92:29-36.

Selma, M., Allende, A., Lopez Galvez, F., Conesa, M.A. and Gil, M. (2008). Disinfection potential of ozone, ultraviolet- $\mathrm{C}$ and their combination in wash water for the fresh-cut vegetable industry. Food microbiology. 25: 809-14.

Sengupta, S., Mukherjee, S., Basak, P. and Majumder, A.L. (2015). Significance of galactinol and raffinose family oligosaccharide synthesis in plants. Frontiers in Plant Science. 6: 656.

Shaidi, F., Arachchi, J.K.V. and Jeon, Y.J. (1999). Food applications of chitin and chitosan. Trends in Food Science and Technology. 10: 37-51.

Sharma, K., Ko, E.Y., Assefa, A.D., Ha, S., Nile, S.H., Lee, E.T. and Park, S.W. (2015). Temperature-dependent studies on the total phenolics, flavonoids, antioxidant activities, and sugar content in six onion varieties. Journal of Food Drug Analisys. 23(2): 243-252.

Shimelis, E. and Rakshit, S. (2005). Effect of microwave heating on solubility and digestibility of proteins and reduction of anti-nutrients of selected common bean (Phaseolus Vulgaris L.) varieties grown in Ethiopia. Italian Journal of Food Science. 17(4): 407-418.

Shirley, B., Kubasek, W.L., Storz, G., Bruggemann, E., Koorneef, M. and Ausubel, F.M. (1995). Analysis of Arabidopsis mutants deficient in flavonoid biosynthesis. The Plant Journal. 8: 659-671.

Siah, S., Wood, J.A., Agboola, S., Konczak, I. and Blanchard, C.L. (2014). Effects of soaking, boiling and autoclaving on the phenolic contents and antioxidant activities of faba beans (Vicia faba L.) differing in seed coat colours. Food Chemistry. 142: 461-468.

Sibul, F., Orcic, D., Vasic, M., Anackov, G., Nadpal, J., Savic, A. and Mimica-Dukic, N. (2016). Phenolic profile, antioxidant and anti-inflammatory potential of herb and root extracts of seven selected legumes. Industrial Crops Production. 83: 641-653.

Silva, E.O. and Bracarense A.P. (2016). Phytic Acid: from antinutritional to multiple protection factor of organic systems. Journal of Food Science. 81(6): 1357-1362.

Simões, A.D.N., Tudela, J.A., Allende, A., Puschmann, R. and Gil, M.I. (2009). Edible coatings containing chitosan and moderate modified atmospheres maintain quality 
and enhance phytochemicals of carrot sticks. Postharvest Biology and Technology. 51: $364-370$.

Simons, L.K. and Sanguansri, P. (1997). Advances in the washing of minimally processed vegetables. Food Australia. 49: 75-80.

Singh, N. and Kayastha, A. M. (2013). A novel application of Cicer $\alpha$-galactosidase in reduction of raffinose family oligosaccharides in soybean flour. Journal of Plant Biochemistry and Biotechnology. 22(3): 353-356.

Singh, B., Singh, J.P., Kaur, A. and Singh, N. (2017). Phenolic composition and antioxidant potential of grain legume seeds: A review. Food Research International. 101: $1-16$.

Singh, B., Singh, J.P., Shevkani, K., Singh, N. and Kaur, A. (2017). Bioactive constituents in pulses and their health benefits. Journal of Food Science and Technology. 54(4): 858-870.

Singh, B., Singh, Jatinder, P., Shevkani, K., Singh, N. and Kaur, A. (2017). Bioactive constituents in pulses and their health benefits. Journal of Food Science and Technology. 54: 1-13.

Singleton, V.L. and Rossi, J.A. (1965). Colorimetry of total phenolics with phospomolobdic-phosphotungstic acid reagents. American Journal of Enology and Viticulture. 16: 144-158.

Singleton, V.L. (1981). Naturally occurring food toxicants: phenolic substances of plant origin common in foods. Advances in Food Research. 27:149-242.

Singleton, V.L., Orthofer, R., and Lamuela-Raventós, R.M. (1999). Analysis of total phenols and other oxidation substrates and antioxidants by means of FolinCiocalteu reagent. Methods in Enzymology. 299: 152-178.

Smith, S.M. and Stow, J.R. (1984). The potential of a sucrose ester coating material for improving the storage and shelf-life qualities of Cox's Orange Pippin apples. Annals of Applied Biology. 104: 383-391.

Soetan, K.O. and Oyewole, O.E. (2009). The need for adequate processing to reduce the anti-nutritional factors in plants used as human foods and animal feeds: A review. African Journal of Food Science. 3(9): 223-232.

Soetan, K.O. (2002). Pharmacological and other beneficial effects of antinutritional factors in plants - A review. African Journal of Biotechnology. 7(25): 4713-4721. 
Soliva-Fortuny, R.C. and Martín-Belloso, O. (2003). New advances in extending the shelf-life of fresh-cut fruits: a review. Trends in Food Science \& Technology. 14(9): 341-353.

Sreerama, Y.N., Sashikala, V.B., Pratape, V.M. and Singh, V. (2012). Nutrients and antinutrients in cowpea and horse gram flours in comparison to chickpea flour: Evaluation of their flour functionality. Food Chemistry. 131(2): 462-468.

Stancheva, I., Nedyalkova, K., Geneva, M., Donkova, R., Hristozkova, M., Perfanova, I., Sichanova, M., Petkova, G., Djonova, E. and Valchovski, H. (2016). Nutritional value of cowpea (Vigna unguiculata L. Walp) grain grown under different soil moisture as affected to the dual inoculation with nitrogen fixing bacteria and arbuscular mycorrhizal fungi. Bulgarian Journal of Soil Science. 1: 112-121.

Stanisavljević, N., Ilic, M., Jovanović, Ž., Cupic, T., Dabić, D., Natić, M., Tesic, Z. and Radovic, S. (2015). Identification of seed coat phenolic compounds from differently colored pea varieties and characterization of their antioxidant activity. Archives of Biological Sciences. 67: 42-42.

Steer, T.E. and Gibson, G.R. (2002). The microbiology of phytic acid metabolism by gut bacteria and relevance for bowel cancer. International Journal of Food Science and Technology. 37: 783-790.

Suslow, T. (1997). Postharvest chlorination. Basic properties and key points for effective disinfection. Publication 8003. University of California. Division of Agriculture and Natural Resources, Davis CA, USA.

Suslow, T and Cantwell M. (1998). Peas: Snow and Snap Pod: Recommendations for Maintaining Postharvest Quality. http://postharvest.ucdavis.edu/Commodity_Resources/Fact_Sheets/Datastores/Veget ables_English/?uid=26\&ds=799 (Accessed January 18, 2018).

Taira, S.., Ono, M. and Matsumoto, N. (1997). Reduction of persimmon astringency by complex formation between pectin and tannins. Postharvest Biology and Technology. 12(3): 265-271.

Tarazona-Díaz, M.P., Viegas, J., Moldao-Martins, M. and Aguayo, E. (2011). Bioactive compounds from flesh and by-product of fresh-cut watermelon cultivars. Journal of the Science of Food and Agriculture. 91:805-812.

Taverne, Y.J., Bogers, A.J., Duncker, D.J. and Merkus, D. (2013). Reactive oxygen species and the cardiovascular system. Oxidative medicine and cellular longevity 
Tchiagam, J.B.N., Youmbi, E., Njintang, N.Y., Bell, J.M. and Nassourou, M.A. (2011). Generation Means Analysis of Seed Sucrose Content in Cowpea (Vigna unguiculata L. Walp.). Asian Journal of Agricultural Sciences. 3: 475-480.

Tharanathan, R.N. and Mahadevamma, S. (2003). Grain legumes, a boon to human nutrition. Trends Food Science and Technology. 14: 507-518.

Thole, J.M. and Nielsen, E. (2008). Phosphoinositides in plants: novel functions in membrane trafficking. Current Opinion in Plant Biology. 11: 620-631.

Thommohaway, C., Uthairatanakij, A. and Jitareerat, P. (2007). Effects of sucrose fatty acid ester on the quality of fresh-cut guava (Psidium guajava). Acta Horticulturae. 746: 455-460.

Thompson L.U. (1993). Potential health benefits and problems associated with antinutrients in foods. Food Research International. 26: 131-149.

Tiong, N., Prasad, K., Yang, B. and Ismail. A. (2010). Bioactive substance contents and antioxidant capacity of raw and blanched vegetables. Innovative Food Science \& Emerging Technologies. 11: 464-469.

Tomás-Barberán, F.A. and Espín, J.C. (2001). Phenolic compounds and related enzymes as determinants of quality in fruits and vegetables. Journal of the Science of Food and Agriculture. 81(9): 853-876.

Tomás-Barberán, F. (2003). Los polifenoles de los alimentos y la salud. Alimentación Nutrición y Salud. 10 (2): 41-53.

Tomás-Callejas, A., López-Velasco, G., Artés, F. and Artés-Hernández, F. (2012). Acidified sodium chlorite optimization assessment to improve quality of fresh-cut tatsoi baby leaves. Journal of Science of Food and Agriculture. 92: 877-885.

Trinidad, P., Mallillin, A.C., Loyola, A.S., Sagum, R.S. and Encabo, R.R. (2010). The potential health benefits of legumes as a good source of dietary fibre. British Journal of Nutrition. 103: 569-574.

Turco, I., Ferretti, G. and Bacchetti, T. (2016). Review of the health benefits of faba bean (Vicia faba L.) polyphenols. Journal of Food and Nutrition Research. 55: 283293.

Turtoi, M. (2013). Ultraviolet light treatment of fresh fruits and vegetables surface: A review. Journal of Agroalimentary Processes and Technology. 19: 325-337.

USDA Nutrient Database for Standard Reference, Release 28. (2018). USDA-ARS, Beltsville, MD. Nutrient Data Laboratory Home Page. Available online at: https:// ndb.nal.usda.gov/ndb/search [03 March 2018]. 
Uyttendaele, M., Neyts, K., Vanderswalmen, H., Notebaert, E. and Debevere, J. (2004). Control of Aeromonas on minimally processed vegetables by decontamination with lactic acid, chlorinated water, or thyme essential oil solution. International Journal of Food Microbiology. 90: 263-271.

Vallejo, F., Tomas-Barberan, F.A. and Garcia-Viguera, C. (2002). Glucosinolates and vitamin $\mathrm{C}$ content in edible parts of broccoli florets after domestic cooking. European Food Research and Technology. 215(4): 310-316.

Van den Ende, W. (2013). Multifunctional fructans and raffinose family oligosaccharides. Frontiers in Plant Science. 4(247): 247.

Vats, P. and Banerjee, U.C. (2004). Production studies and catalytic properties of phytases (myo-inositolhexakisphosphate phosphohydrolases): An overview. Enzyme and Microbial Technology. 35(1): 3-14.

Vicente, A.R., Pineda, C., Lemoine, L., Civello, P.M., Martínez, G.A. and Chaves, A.R. (2005). UV-C treatments reduce decay, retain quality and alleviate chilling injury in pepper. Postharvest Biology and Technoly. 35: 69-78.

Vidal-Valverde, C., Frias, J., Sotomayor, C., Diaz-Pollan, C., Fernandez, M. and Urbano, G. (1998). Nutrients and antinutritional factors in faba beans as affected by processing. Zeitschrift für Lebensmitteluntersuchung und -Forschung A. 207: 140145.

Vidal-Valverde, C., Frías, J., Hernández, A., Martín-Álvarez, P.J., Sierra, I., Rodríguez, C., Blázquez, I. and Vicente, G. (2003). Assessment of nutritional compounds and antinutritional factors in pea (Pisum sativum) Seeds. Journal of the Science of Food and Agriculture. 83: 298 - 306.

Vilariño, M., Métayer, P., Crépon, J., Katell and Duc, G. (2009). Effects of varying vicine, convicine and tannin contents of faba bean seeds (Vicia faba L.) on nutritional values for broiler chicken. Animal Feed Science and Technology. 150. 114-121.

Voragen, A.G.J. (1998). Technological aspects of function food-related carbohydrates. Trends in Food Science \& Technology. 328-335.

Walkling-Ribeiro, M., Noci, F., Cronin, D.A., Lyng, J.G. and Morgan, D.J. (2010). Shelf life and sensory attributes of a fruit smoothie-type beverage processed with moderate heat and pulsed electric fields. Food Science and Technology. 43:10671073. 
Wang, N., Hatcher, D.W., Toews, R. and Gawalko, E.J. (2009). Influence of cooking and dehulling on nutritional composition of several varieties of lentils (Lens culinaris). LWT - Food Science and Technology. 42(4): 842-848.

Warf, C.C. (2001). The chemistry and mode of action of acidified sodium chlorite. IFT Annual Meeting pp. 1-91.

Warriner, K., Huber, A., Namvar, A., Fan, W. and Dunfield, K. (2009). Recent advances in the microbial safety of fresh fruits and vegetables. Advances in food and nutrition research. 57: 155-208.

Watada, A.E., Ko, N.P. and Minott, D.A. (1996). Factors affecting fresh-cut horticultural products. Postharvest Biology and Technology. 9: 115-125.

Wen, T.N., K. Prasad, N., Yang, B. and Ismail, A. (2010). Bioactive substance contents and antioxidant capacity of raw and blanched vegetables. Innovative Food Science \& Emerging Technologies. 11(3): 464-469.

Wilhelm Thomé O. (1885). Flora von Deutschland, Österreich und der Schweiz.

Wilson, M., Stanley, R.A., Eyles, A. and Ross, T. (2017). Innovative processes and technologies for modified atmosphere packaging of fresh and fresh-cut fruits and vegetables: A review. Critical Reviews in Food Science and Nutrition. 59(3):00-00.

Wong, D.W.S., Tillin, S.J., Hudson, J.S. and Pavlath, A.E. (1994). Gas exchange in cut apples with bilayer coatings. Journal of Agricultural and Food Chemistry. 42: 22782285.

Wongputtisin, P., Ramaraj, R., Unpaprom, Y., Kawaree, R. and Pongtrakul, N. (2015). Raffinose family oligosaccharides in seed of Glycine max cv. and potential source of prebiotic substances. International Journal of Food Science \& Technology. 50: 17.

Wu, X. and Kang, J. (2011). Phytochemicals in soy and their health effects. In I. Rasooli (Ed.), Phytochemicals - bioactivities and impact on health (pp. 43-76). InTech.

Xiong, S., Yao, X. and Li, A. (2013). Antioxidant Properties of Peptide from Cowpea Seed. International Journal of Food Properties. 16: 1245-1256.

$\mathrm{Xu}$, B. and Chang, S.K. (2008). Effect of soaking, boiling, and steaming on total phenolic contentand antioxidant activities of cool season food legumes. Food Chemistry. 110(1): 1-13. 
Xu, B. and Chang, S.K.C. (2012). Comparative study on antiproliferation properties and cellular antioxidant activities of commonly consumed food legumes against nine human cancer cell lines. Food Chemistry. 134(3): 1287-96.

Xu, Y., Cartier, A., Obielodan, M., Jordan, K., Hairston, T., Shannon, A. and Sismour, E. (2016). Nutritional and anti-nutritional composition, and in vitro protein digestibility of Kabuli chickpea (Cicer arietinum L.) as affected by differential processing methods. Journal of Food Measurement and Characterization. 10: 625633.

Xue, H., Chen, X. and Li, G. (2007). Involvement of phospholipids signaling in plant growth and hormone effects. Plant Biology. 10: 483-489.

Yadahally, N., Sreerama, N.Y., Vadakkoot, B., Sashikala, V., Pratape M. and Vasudeva S. (2012). Nutrients and antinutrients in cowpea and horse gram flours in comparison to chickpea flour: Evaluation of their flour functionality. Food Chemistry. 131(2): 462-468.

Yadav, N., Kaur, D., Malaviya, R., Singh, M., Fatima, M. and Singh, L. (2018). Effect of thermal and non-thermal processing on antioxidant potential of cowpea seeds. International Journal of Food Properties. 21(1): 437-451.

Yasmin, A., Zeb, A., Khalil, A. W., Paracha, G. M. and Khattak, A. B. (2008). Effect of processing on anti-nutritional factors of red kidney bean (Phaseolus vulgaris) grains. Food and Bioprocess Technology. 1(4): 415-419.

Yaun, B., Sumner, S., Eifert, J. and Marcy, J. (2004). Inhibition of pathogens on fresh produce by ultraviolet energy. International Journal of Food Microbiology. 90: 1-8.

Yildiz, F. (1994). Initial preparation, handling and distribution of minimally processed refrigerated fruits and vegetables. In: Wiley, R.C. (Ed.). Minimally Processed Refrigerated Fruits and Vegetables. Chapman \& Hall, New York, USA, pp. 15-49.

Youngmok, K., Jeffrey, B.K. and Stephen, T.T. (2007). Antioxidant phytochemical and fruit quality changes in mango (Mangifera indica L.) following hot water immersion and controlled atmosphere storage. Food Chemistry. 105 (4): 1327-1334.

Yousuf, B., Qadri, O. and Srivastava, A. (2018). Recent developments in shelf-life extension of fresh-cut fruits and vegetables by application of different edible coatings: A review. LWT- Food Science and Technology. 89.

Zapata, S. and Dufour, J.P. (1992). Ascorbic, dehydroascorbic and isoascorbic and simultaneous determinations by reverse phase ion interaction HPLC. Journal of Food Science. 57: 506-511. 
Zartl, B., Silberbauer, K., Loeppert, R., Viernstein, H., Praznik, W. and Mueller, M. (2018). Fermentation of non-digestible raffinose family oligosaccharides and galactomannans by probiotics. Food \& Function. 9(3): 1638-1646.

Zenoozian, M.S. (2011). Combined effect of packaging method and temperature on the leafy vegetables properties. International Journal of Environmental Science and development. 2:124-127.

Zhang, D. and Hamauzu, Y. (2004). Phenolics, ascorbic acid, carotenoids and antioxidant activity of broccoli and their changes during conventional and microwave cooking. Food Chemistry. 88: 503-509.

Zhang, B., Deng, Z., Ramdath, D. D., Tang, Y., Chen, P. X., Liu, R., and Tsao, R. (2015). Phenolic profiles of 20 Canadian lentil cultivars and their contribution to antioxidant activity and inhibitory efects on $\alpha$-glucosidase and pancreatic lipase. Food Chemistry. 172: 862-872.

Zhou, L., Tey, C.Y., Bingol, G. and Bi, J. (2016). Effect of microwave treatment on enzyme inactivation and quality change of defatted avocado puree during storage. Innovative Food Science and Emerging Technologies. 37: 61-67.

Zia-Ul-Haq, M., Ahmad, S., Amarowicz, R. and De Feo, V. (2013). Antioxidant activity of the extracts of some cowpea (Vigna unguiculata (L) Walp.) cultivars commonly consumed in Pakistan. Molecules. 18: 2005-2017.

Zulet, M.A., and Martínez, J.A. (2001). Dieta mediterránea: legumbres y colesterolemia. Revista chilena de nutrición. 28(2): 312-320. 


\section{APPENDIX \\ COPIES OF THE E-MAILS OF ACCEPTANCE OF THE PUBLICATIONS OF WHICH THE THESIS CONSISTS AND IMPACT INDEX}

- Collado, E., Klug, T.V, Martínez-Sánchez, A., Artés-Hernández, F., Aguayo, E., Artés, F., Fernández, J.A. and Gómez, P.A. 2017. Immature pea seeds. Effect of storage under modified atmosphere packaging and sanitation with acidified sodium chlorite. Journal of the Science of Food and Agriculture. 97: 4370-4378. http://dx.doi.org/10.1002/jsfa.8513.

\section{Accept - Journal of the Science of Food and Agriculture - Manuscript JSFA-16-2696.R1}

Journal of the Science of Food and

Agriculture <onbehalfof+JSFA+wiley.com@manuscriptcentral.com>

Dom 25/06/2017 23:35

JSFA-16-2696.R1

Dear Dr Gómez,

I am delighted to inform you that your manuscript, "IMMATURE PEA SEEDS. EFFECT OF STORAGE UNDER MODIFIED ATMOSPHERE PACKAGING AND SANITATION WITH ACIDIFIED SODIUM CHLORITE", is now accepted for publication in the Journal of the Science of Food and Agriculture. Within the next few days the corresponding author will receive an email from Wiley's Author Services system which will ask them to log in and will present them with the appropriate license for completion. Your article cannot be published until the publisher has received the appropriate signed license agreement.

The article will be published online within the next few days as an Accepted Article. This will be an unedited version but will be fully citable and will constitute the paper's official publication date.

Once the paper has been copy-edited and typeset you shall receive the proofs. Please check the proof carefully and return any corrections. After any amendments have been made, the Accepted Article will be taken down, and the final version will be published in Early View, before being assigned to an issue.

If material from another publisher has been used, and you have not already done so, please provide scanned copies of the Permissions form by emailing them to JSFAproofs@wiley.com.

The Permission Request form can be found at: 
http://onlinelibrarystatic.wiley.com/central/prf/UKsprf.pdf

Now that your manuscript has been accepted for publication you have the option to publish your article with open access so that it will be accessible to subscribers and non-subscribers of this journal. Your article can be published OnlineOpen in return for a payment of an open access publication fee. You can complete the payment of the open access publication fee via the

OnlineOpen Form which you can find at:

https://authorservices.wiley.com/bauthor/onlineopen order.asp

Thank you for your support and we look forward to seeing more of your work in the future.

Yours sincerely,

Dr Carol Wagstaff

Associate Editor

Journal of the Science of Food and Agriculture

JSFA@wiley.com

2017 Journal Impact Factor \& percentile rank in category for: JOURNAL OF THE SCIENCE OF FOOD AND AGRICULTURE

\subsection{9}

2017 Journal Impact Factor

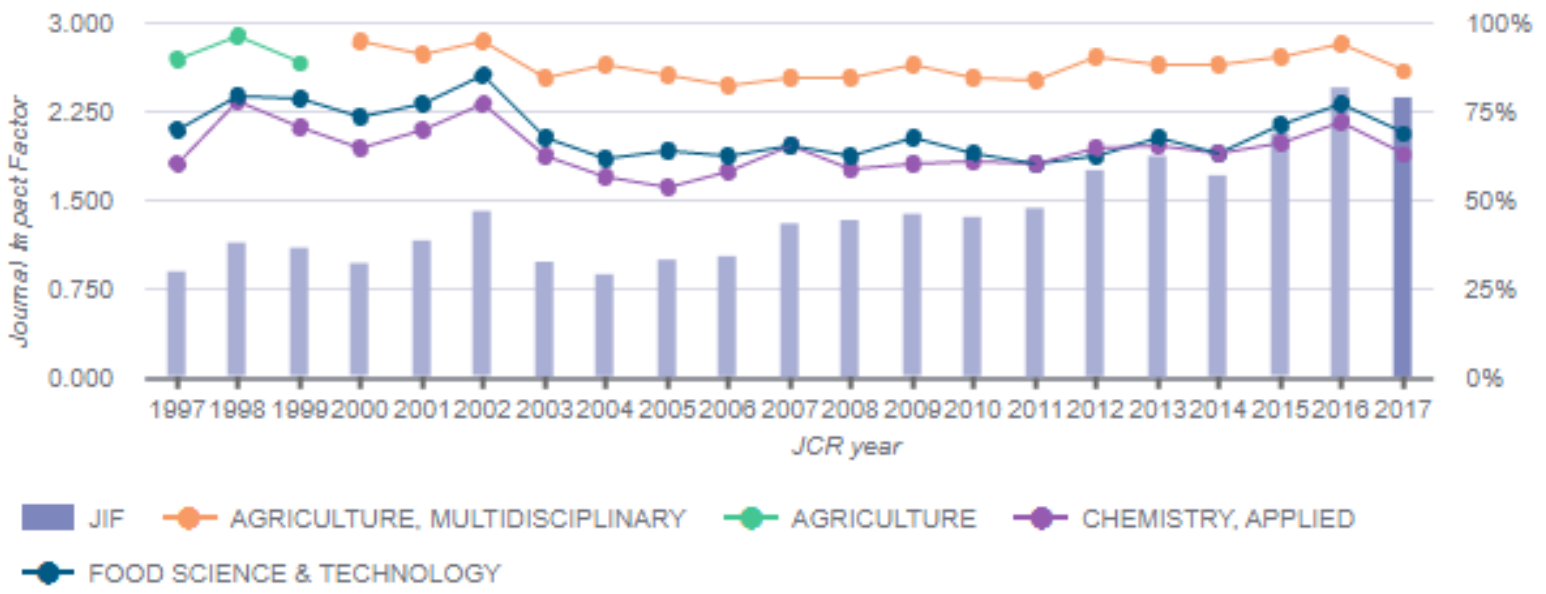


- Collado, E., Venzke Klug, T., Martínez-Hernández, G. B., Artés-Hernández, F., Martínez-Sánchez, A., Aguayo, E., Artés, F., Fernández, J.A., Gómez, P.A. (2019). UV-C pretreatment of fresh-cut faba beans (Vicia faba) for shelf life extension: Effects of domestic microwaving for consumption. Food Science and Technology International. In press. https://doi.org/10.1177/1082013219873227.

\section{FSTI-19-0097.R1; Final clean files required for production}

Food Science and Technology

International <onbehalfof@manuscriptcentral.com>

Mar 30/07/2019 12:53

FSTI-19-0097.R1 - UV-C PRETREATMENT OF FRESH-CUT FABA BEANS (Vicia faba) FOR SHELF LIFE EXTENSION. EFFECTS OF DOMESTIC MICROWAVING FOR CONSUMPTION

Dear Dr. Gomez Di Marco:

Hope you are doing well.

I am glad to inform you that as your manuscript is accepted for production, we require final clean accepted files.

(a) Please provide clean accepted editable manuscript and title page.

(b) Please provide figures in TIFF/EPS/JPEG/XLS formats only. Tables should be in excel/word format.

In addition, while checking the manuscript the citation for figure 2 was not present. Request you to update the manuscript with the same.

Look forward to receiving the files.

Sincerely,

Shivani Barthwal

Food Science and Technology International

2018 Journal Impact Factor \& percentile rank in category for: FOOD SCIENCE AND

TECHNOLOGY INTERNATIONAL

\subsection{1}

2018 Journal Impact Factor

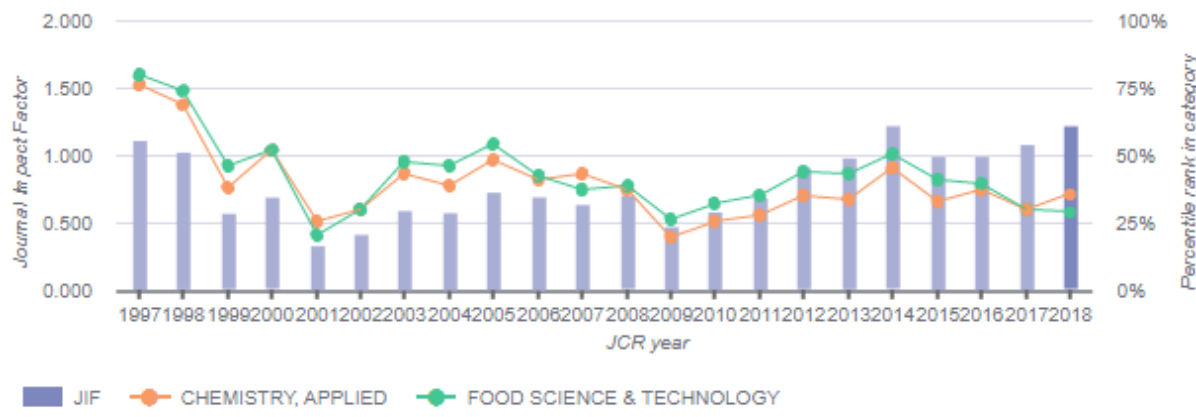


- Collado, E., Venzke Klug, T., Artés-Hernández, F., Aguayo, E., Artés, F., Fernández, J.A., Gómez, P.A. (2019). Quality changes in nutritional traits of fresh-cut and then microwaved cowpea seeds and pods. Food and Bioprocess Technology. 12: 338-346. http://dx.doi.org/10.1007/s11947-018-2214-2

\section{Decision on your manuscript \#FABT-D-18-00821R2}

Food and Bioprocess Technologies <"<em@editorialmanager.com>">

Lun 12/11/2018 14:22

Dear Dr. Gómez:

We are pleased to inform you that your manuscript, "QUALITY CHANGES IN NUTRITIONAL TRAITS OF FRESH-CUT AND THEN MICROWAVED COWPEA SEEDS AND PODS" has been accepted for publication in Food and Bioprocess Technology.

For queries regarding your accepted paper, please click the following link http://www.springer.com/11947; then click on "Contacts", and then "Production Editor", complete the query form and click "Submit".

Please remember to always include your manuscript number, \#FABT-D-18-00821R2, whenever inquiring about your manuscript. Thank you.

Best regards,

Jorge Barros-Velazquez, Ph.D.

Food and Bioprocess Technology

2018 Journal Impact Factor \& percentile rank in category for: Food and Bioprocess Technology

\subsection{2}

2018 Journal Impact Factor

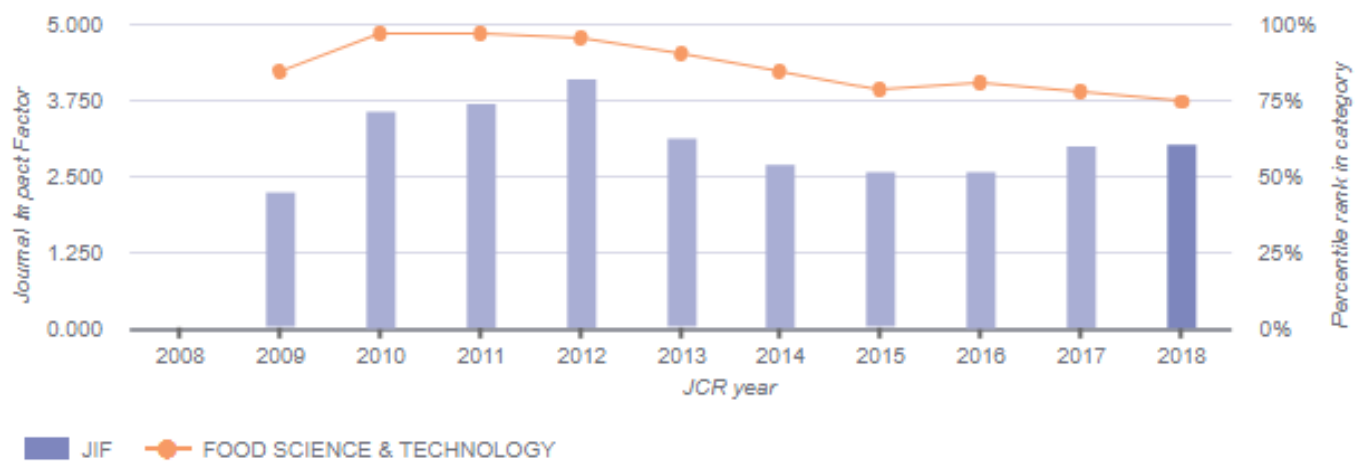


Collado, E., Venzke Klug, T., Martínez-Hernández, G. B Artés-Hernández, F., MartínezSánchez, A., Aguayo, E., Artés, F., Fernández, J.A., Gómez, P.A. 2019. Nutritional and quality changes of minimally processed faba (Vicia faba L.) beans during storage: Effects of domestic microwaving. Postharvest Biology and Technology. https://doi.org/10.1016/j.postharvbio.

\section{Postharvest Biology and Technology}

\section{From: Chris Watkins}

To: Perla Gomez

subject: Your manuscript POSTEC_2018_1113_R1 has been accepted

Ref: POSTEC_2018_1113_R1

Title: NUTRITIONAL AND QUALITY CHANGES OF MINIMALLY PROCESSED FABA (Vicia faba L.) BEANS DURING STORAGE: EFFECTS OF DOMESTIC MICROWAVING

Journal: Postharvest Biology and Technology

Dear Dr. Gomez,

I am pleased to inform you that your paper has been accepted for publication.

Your accepted manuscript will now be transferred to our production department. We will create a proof which you will be asked to check. You can read more about this here. Meanwhile, you will be asked to complete a number of online forms required for publication. If we need additional information from you during the production process, we will contact.

Thank you for submitting your work to Postharvest Biology and Technology. We hope you consider us again for future submissions.

Kind regards,

\section{Chris Watkins}

Associate Editor

Postharvest Biology and Technology

2018 Journal Impact Factor \& percentile rank in category for: POSTHARVEST

\section{BIOLOGY AND TECHNOLOGY}

\subsection{7}

2018 Journal Impact Factor

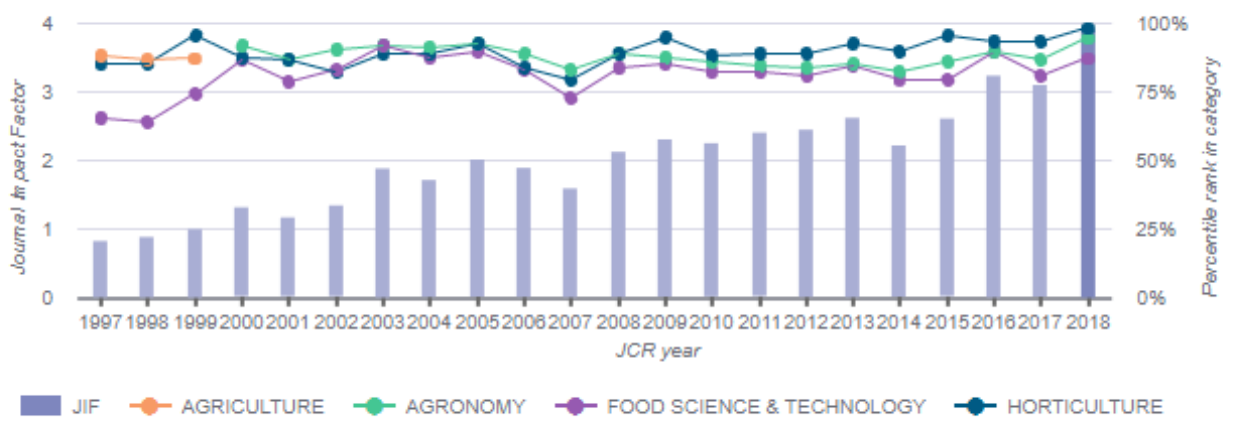

